\title{
Does insulin signalling decide glucose levels in the fasting steady state?
}

\author{
Manawa Diwekar-Joshi ${ }^{1}$
}

Milind Watve $e^{1,2^{*}}$

1. Indian Institute of Science Education and Research, Pune, India

2. Deenanath Mangeshkar Hospital and Research Centre, Pune, India

*for correspondence:

Keywords: physiology, steady-state, glucose homeostasis, causality 


\section{Abstract}

Recent work has suggested that altered insulin signalling may not be central to the pathophysiology of type 2 diabetes as classically believed. We critically re-examine the role of insulin in glucose homeostasis using five different approaches (i) systematic review and meta-analysis of tissue specific insulin receptor knock-outs, (ii) systematic review and metaanalysis of insulin suppression and insulin enhancement experiments, (iii) differentiating steady-state and post-meal state glucose levels in streptozotocin treated rats in primary experiments (iv) mathematical and theoretical considerations and (v) glucose insulin relationship in human epidemiological data. All the approaches converge on the inference that although insulin action is hastens the return to a steady-state after a glucose load, there is no evidence that insulin action determines the steady-state level of glucose. The inability to differentiate steady state causality from perturbed state causality has led to misinterpretation of the evidence for the role of insulin in glucose regulation.

\section{Key words}

Causality, glucose homoeostasis, insulin, steady-state, type 2 diabetes 


\section{Introduction}

\section{Why is insulin believed to regulate fasting blood sugar: A burden of history?}

After the classical demonstration by Claud Bernard that damage to medulla oblongata causes hyperglycaemia (1), the second major breakthrough was the demonstration by von Mering and Minkowski that pancreatectomy resulted in hyperglycaemia (2) and further that pancreatic extracts resulted in lowering of plasma glucose. The active principle eventually purified became known as insulin (3). The discovery and success of insulin in treating diabetes was so overwhelming that insulin became the key molecule in glucose homeostasis and the role of brain and other mechanisms were practically forgotten. It should be noted that the prevalent type of diabetes then was what we would call type 1 diabetes (T1D) today in which there is almost complete destruction of pancreatic $\beta$-cells. The distinction between type 1 and 2 developed gradually over the next five decades along with the realization that insulin levels may be normal or raised in type 2 diabetes (T2D) and that a substantial population of $\beta$-cells survives lifelong (4-6). However, by now the thinking about glucose homeostasis was so insulin centred, that the inability of normal or raised levels of insulin to keep plasma glucose normal was labelled as "insulin resistance" without adequately examining and eliminating alternative possibilities and the concept got wide uncritical acceptance. Although insulin resistance as a phenomenon is well established and its molecular mechanisms elucidated with substantial details, the question whether altered insulin signalling is solely or mainly responsible for fasting hyperglycaemia of $\mathrm{T} 2 \mathrm{D}$, or other insulin independent mechanisms play a significant role is not clearly answered.

There are multiple reasons to doubt and re-examine the role of insulin in glucose regulation in relation to T2D (7-9). Exogenous insulin and other insulin-centred lines of treatment have 
largely failed to reduce diabetic complications and mortality in T2D although short term

27 glucose lowering may be achieved (10-15). In the long run even the glucose normalization

28 goal is not achieved in majority of cases $(12,14)$. A number of mechanisms are known to

29 influence glucose dynamics, partially or completely independent of insulin signalling,

30 including autonomic signals $(16,17)$, glucocorticoids (18-21), insulin independent glucose

31 transporters (22) and certain other hormones and growth factors (23-26). Analysis of multi-

32 organ signalling network models have also raised doubts about the central role of insulin and

33 insulin resistance in T2D (27).

35 The definitions as well as clinical measures of insulin resistance are such that the effects of

36 all other mechanisms are accounted for under the name of "insulin resistance". For example,

37 the HOMA-IR index is calculated as a product of fasting glucose and fasting insulin $(28,29)$.

38 The belief that this product reflects insulin resistance is necessarily based on the assumption

39 that insulin signalling alone quantitatively determines glucose level in a fasting steady state.

40 The assumption has seldom been critically examined. If any other mechanisms are

41 contributing to raised fasting glucose levels, they will be included in the HOMA-IR index

42 going by the way it is calculated and would be labelled as insulin resistance. We have

43 previously showed using mathematical and statistical tools of causal analysis (30) that the

44 classical pathway of obesity induced insulin resistance leading to a hyperinsulinemic

45 normoglycemic prediabetic state and the faithfulness of HOMA indices in measuring insulin

46 resistance cannot be simultaneously true. Either the HOMA indices do not represent insulin

47 resistance faithfully or the classically believed pathway of compensatory insulin response

48 leading to hyperinsulinemic normoglycemic state is wrong according to this analysis (30). 
50 We examine here the long held belief that altered insulin signalling is responsible for fasting

51 as well as post prandial hyperglycemia in T2D using five different approaches (i) Systematic

52 review and meta-analysis of experiments involving tissue specific insulin receptor knock-outs

53 (IRKOs) (ii) Systematic review and meta-analysis of experiments to chronically raise or

54 lower insulin levels (iii) Primary experiments on streptozotocin (STZ) induced

55 hyperglycaemia in rats that differentiate between steady and perturbed-state (iv) Examining

56 the insulin resistance hypothesis for being mathematically possible and theoretically sound

57 (v) Analysis of insulin-glucose relationship in steady-state versus post-meal perturbed-state in

58 human epidemiological data for testing the predictions of mathematical models. The first

59 three approaches have the advantage of using specific molecular interventions where the

60 target is precisely known. For the meta-analyses we chose mechanisms of insulin level/action

61 modification which have been used extensively and have been reproduced by multiple labs

62 world over. The possible disadvantage is that they are mostly animal experiments and doubts

63 are expressed about whether the results are directly relevant to humans (31-33). However,

64 some of the experiments reported are human and they converge with the inferences of the

65 animal experiments. In the last two approaches, human epidemiological data are used in

66 which the experimental molecular precision is not expected, but we test certain specific

67 predictions of the insulin resistance hypotheses using novel analytical approaches and

68 examine whether they converge on similar inferences. The convergence of human and animal

69 data is important to reach robust conclusions. 


\section{Systematic review and meta-analysis of experiments involving tissue specific insulin} receptor knock-outs

The first step in insulin signalling is the binding of insulin to insulin receptor (34). The downstream actions of this event finally lead to insulin-dependent glucose uptake in insulin dependent tissues of the body. Experimentally, disruption of insulin signalling is achieved by knocking out or inhibiting various players in the signalling cascade. We chose to look at the effects of knocking out the tissue specific insulin receptor on fasting and post-meal or post glucose load levels in rodent models. Studying tissue specific insulin receptor knockouts enables us to differentiate between the roles of insulin signalling in different tissues. A classical belief is that the post-meal glucose curve is mainly influenced by the rate of glucose uptake by tissues, mainly muscle, whereas the fasting glucose levels are mainly determined by the rate of liver glucose production (35). If this belief is true one expects that muscle specific knockout would mainly affect the GTT curve but may not affect fasting glucose level, whereas liver specific knockout would mainly affect the fasting glucose level.

\subsection{Methods}

The details of the systematic literature review are given in table 1 . The details of the experiments of the shortlisted studies can be seen in the table 1 of the supplementary information 1 which shows that similar methods have been utilised to create the knockouts and therefore a comparative analysis is justified. 
94 Table 1: Systematic literature review for studies on tissue specific insulin receptor knockouts (meta-analysis 1).

\begin{tabular}{|c|c|}
\hline $\begin{array}{l}\text { Meta-analysis } 1 \rightarrow \\
\text { Task performed } \downarrow\end{array}$ & Insulin receptor knockout \\
\hline $\begin{array}{l}\text { Key word(s) used for the first search on } \\
\text { the PubMed/MEDLINE data-base }\end{array}$ & "insulin receptor knockout" \\
\hline Number of hits in the first search & 78 \\
\hline Inclusion criteria for primary screening & $\begin{array}{l}\text { Study showing experiments with IRKOs in which } \\
\text { GTT curve has been reported }\end{array}$ \\
\hline $\begin{array}{l}\text { Number of papers shortlisted based on } \\
\text { primary screening }\end{array}$ & 36 \\
\hline $\begin{array}{l}\text { Inclusion criteria for secondary } \\
\text { screening }\end{array}$ & $\begin{array}{l}\text { Study showing similar methods of making the insulin } \\
\text { receptor knockout; had fasting and post glucose bolus } \\
\text { readings of the control and knockout }\end{array}$ \\
\hline $\begin{array}{l}\text { Number of papers shortlisted based on } \\
\text { screening the full-text and back } \\
\text { referencing (data for meta-analysis } \\
\text { extracted from these papers) }\end{array}$ & 16 \\
\hline $\begin{array}{l}\text { List of publications used in the final } \\
\text { meta-analysis: references numbers }\end{array}$ & $(36-51)$ \\
\hline
\end{tabular}

96 2.1.1 Statistical approach for meta-analysis: Although we short-listed papers that used

97 similar methods, small differences in protocols can make considerable differences. As the

98 results will reveal, there is substantial variation in results across studies. Therefore we use

99 non-parametric methods for analysing the pooled data. We first look at in how many of the

100 experiments the treatment mean in greater than the control mean and in how many it is less. If 
101

102

103

104

105

107

108

109

110

this difference is significant, we conclude that there is sufficient qualitative consistency

across experiments to reach a reliable inference. If there is a consistent direction of

difference, we look at how many are individually significant. As a conservative approach we avoid pooling data quantitatively since across studies there are differences in age or weight of animals, number of days after treatment, number of hours of fasting and other variables. This approach is maintained throughout all meta-analyses reported.

\subsection{Results of the IRKO meta-analysis}

We shortlisted 16 papers with 46 independent experiments in which glucose tolerance curves of insulin receptor knockouts and controls were compared (table 1 of supplementary information 1). The experiments could be segregated in four different tissue specific knockouts for the analysis: Liver insulin receptor knockout (LIRKO), Muscle insulin receptor knockout (MIRKO), fat/adipose insulin receptor knockout (FIRKO) and $\beta$-cell insulin receptor knockout $(\beta I R K O)$. A generalized trend in the total picture summed up over all four IRKOs seen in the meta-analysis was that along the GTT curve, significantly higher glucose levels are seen in the knockouts as compared to the controls, particularly and consistently at 30, 60 and 120 minutes. However, the fasting glucose level was not significantly different in the meta-analysis. In some studies, fasting glucose was significantly greater in the knockouts than the controls, however in some other studies it is significantly lower as well. In 29 out of 46 experiments there was no significant difference (Table 2) in the fasting glucose levels of knockouts and controls. This trend was consistently seen in MIRKO, LIRKO and $\beta I R K O$.

Only in FIRKO there were greater number of studies showing fasting glucose significantly higher in the knockouts than in the controls, but in the non-parametric meta-analysis the trend was not significant. Also, only in FIRKO, the 30, 60- and 120-minute glucose was not 
significantly different in the knockouts than the controls. It is notable in particular that in none of LIRKO experiments the fasting sugar was significantly higher than the controls. This contradicts the classical belief that liver insulin resistance is mainly responsible for fasting hyperglycaemia in T2D $(35,52)$.

A possible problem in comparing fasting glucose across different studies was that different fasting intervals have been used ranging from 4 to 16 hours. No study clearly reported how much time is required to reach a steady-state in a knockout. In 10 of the experiments in which fasting time was reported as 16 hours, none had fasting sugar significantly different for controls. In the 13 experiments in which it was high, the fasting duration was between 4 to 12 hours or not precisely reported. Therefore, it is likely that in some of the experiments, glucose steady-state was not yet achieved at the time point defined as fasting. This bias increases the probability that higher fasting glucose is reported for the knockouts. However, since we do not see a significant difference in the meta-analysis, the inference that IRKO does not alter fasting glucose is unlikely to be a result of the bias. In fact, any possible correction to the bias might further reduce the apparent residual difference. Therefore, in spite of some inconsistency across studies, a robust generalization is that IRKOs have significantly increased plasma glucose over controls at 30 to 120 minutes post glucose load but they do not appear to affect steady-state fasting glucose. The time required to reach the steady state is nevertheless increased.

Table 2: Meta-analysis of the fasting and post-feeding glucose levels in the control and IRKOs. The table shows, out of the total number of experiments used for the analysis, in how many the mean of the knockouts (T) was greater than the control means (C) and in how many the trend was reverse. This relative position of the means across studies is compared non-parametrically to see whether the trend across studies was non-random, significant ones being indicated by asterisk. The table also gives in how many studies $\mathrm{T}$ was significantly 
152 greater than $\mathrm{C}$ and vice versa. It can be seen that for fasting glucose the difference is not significant in majority

153 of studies and where there is statistical significance there is lack of consistency across studies. However, at 30 ,

15460 and 120 minutes the knockouts have consistently elevated levels of glucose as compared to the

155 corresponding controls.

\begin{tabular}{|c|c|c|c|c|c|c|}
\hline & $\begin{array}{c}\text { Total } \\
\text { studies }\end{array}$ & $\mathbf{T}>\mathbf{C}$ & $\mathbf{T}<\mathbf{C}$ & $\begin{array}{c}p \text { using chi } \\
\text { square }\end{array}$ & $\begin{array}{c}\mathbf{T}>\mathrm{C} \text { individually } \\
\text { significant }\end{array}$ & $\begin{array}{c}\mathbf{T}<\mathrm{C} \text { individually } \\
\text { significant }\end{array}$ \\
\hline \multicolumn{7}{|l|}{ All IRKOs } \\
\hline Fasting & 46 & 25 & 20 & 0.454 & 13 & 4 \\
\hline 15 minutes & 14 & 7 & 7 & 0.999 & 4 & 2 \\
\hline 30 minutes & 40 & 36 & 4 & $<0.0001 *$ & 22 & 1 \\
\hline 60 minutes & 40 & 36 & 4 & $<0.0001^{*}$ & 24 & 1 \\
\hline 120 minutes & 46 & 37 & 9 & $<0.0001 *$ & 24 & 2 \\
\hline \multicolumn{7}{|l|}{ FIRKO } \\
\hline Fasting & 12 & 9 & 3 & 0.083 & 9 & 1 \\
\hline 15 minutes & 3 & 1 & 2 & 0.566 & 1 & 1 \\
\hline 30 minutes & 9 & 7 & 2 & 0.095 & 6 & 1 \\
\hline 60 minutes & 9 & 7 & 2 & 0.095 & 5 & 1 \\
\hline 120 minutes & 12 & 9 & 3 & 0.83 & 7 & 2 \\
\hline \multicolumn{7}{|l|}{ MIRKO } \\
\hline Fasting & 10 & 3 & 7 & 0.205 & 0 & 2 \\
\hline 15 minutes & 6 & 3 & 3 & 0.999 & 1 & 0 \\
\hline 30 minutes & 10 & 9 & 1 & $0.011 *$ & 3 & 0 \\
\hline 60 minutes & 10 & 9 & 1 & $0.011 *$ & 3 & 0 \\
\hline 120 minutes & 10 & 6 & 4 & 0.527 & 3 & 0 \\
\hline \multicolumn{7}{|l|}{ LIRKO } \\
\hline Fasting & 9 & 4 & 5 & 0.739 & 0 & 0 \\
\hline 15 minutes & 1 & 1 & 0 & N.A. & 0 & 0 \\
\hline
\end{tabular}


bioRxiv preprint doi: https://doi.org/10.1101/553016: this version posted July 16,2019 . The copyright holder for this preprint (which was not certified by peer review) is the author/funder, who has granted bioRxiv a license to display the preprint in perpetuity. It is made available under aCC-BY-ND 4.0 International license.

\begin{tabular}{|c|c|c|c|c|c|c|}
\hline 30 minutes & 9 & 9 & 0 & $0.003 *$ & 6 & 0 \\
\hline 60 minutes & 9 & 9 & 0 & $0.003 *$ & 7 & 0 \\
\hline 90 minutes & 9 & 9 & 0 & $0.003 *$ & 5 & 0 \\
\hline 120 minutes & 9 & 7 & 2 & 0.094 & 4 & 0 \\
\hline \multicolumn{7}{|l|}{ BIRKO } \\
\hline Fasting & 8 & 6 & 2 & 0.157 & 4 & 0 \\
\hline 15 minutes & 2 & 2 & 0 & 0.157 & 2 & 0 \\
\hline 30 minutes & 8 & 7 & 1 & $0.033 *$ & 6 & 0 \\
\hline 60 minutes & 8 & 7 & 1 & $0.033 *$ & 7 & 0 \\
\hline 90 minutes & 4 & 4 & 0 & $0.046^{*}$ & 4 & 0 \\
\hline 120 minutes & 8 & 8 & 0 & $0.0046^{*}$ & 7 & 0 \\
\hline
\end{tabular}

156

157 
bioRxiv preprint doi: https://doi.org/101101/553016 this version posted July 16 2019. The copyright holder for this preprint (which was not certified by peer review) is the author/funder, who has granted bioRxiv a license to display the preprint in perpetuity. It is made available under aCC-BY-ND 4.0 International license.

158 Figure 1: Glucose levels for control (black squares) and FIRKO (red squares) at steady-state and perturbed

159 state. The forest plot is normalized to the control and difference of FIRKO glucose levels plotted with $\pm 95 \%$ CI.

160 (A) fasting glucose and (B) to (E) post glucose load glucose at different time intervals.

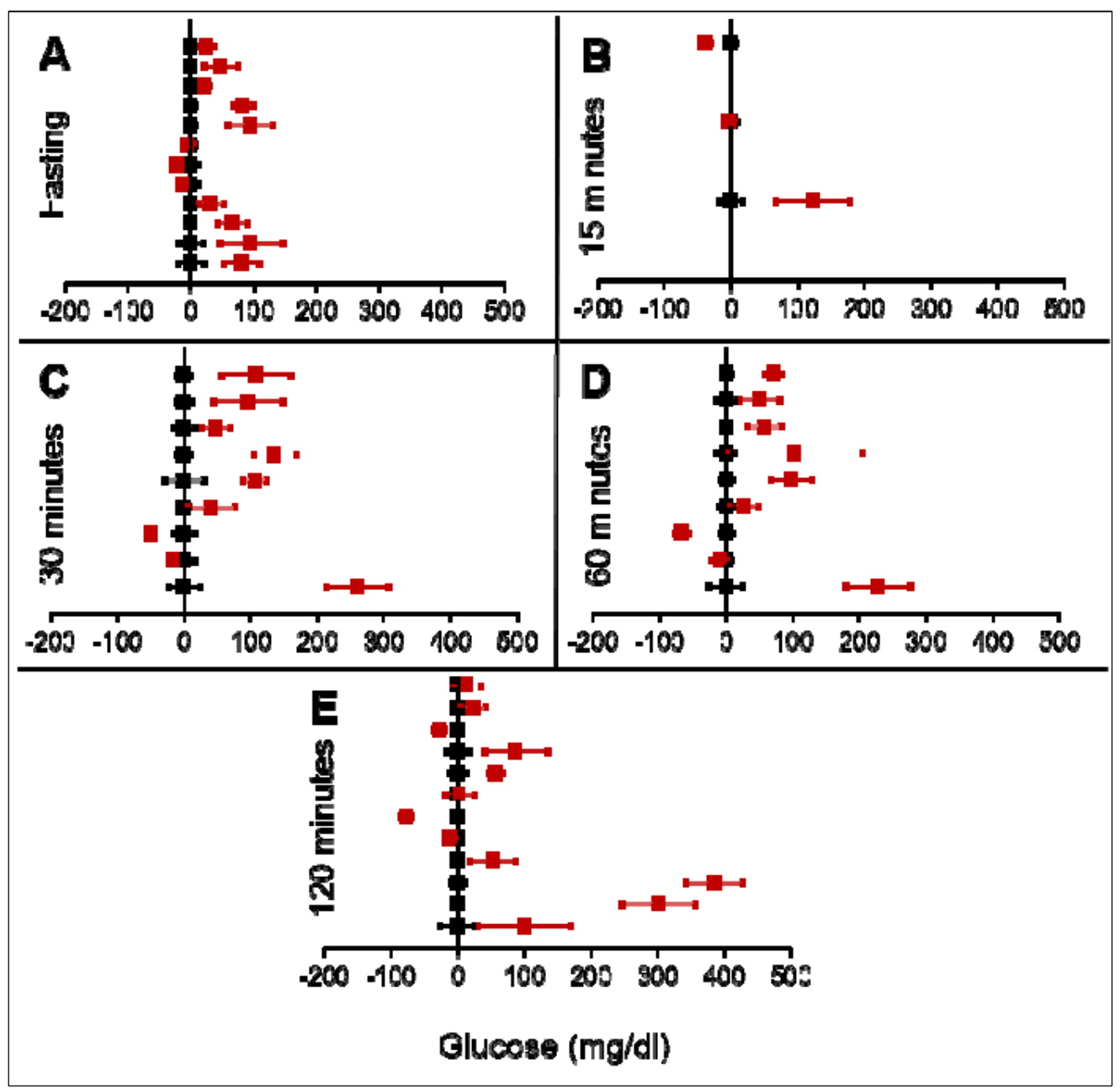


bioRxiv preprint doi: https://doi.org/101101/553016 this version posted July 16 2019. The copyright holder for this preprint (which was not certified by peer review) is the author/funder, who has granted bioRxiv a license to display the preprint in perpetuity. It is made available under aCC-BY-ND 4.0 International license.

164 Figure 2: Results with MIRKO represented as in figure 1. Note that fasting glucose does not differ from the

165 control in any of the experiments.

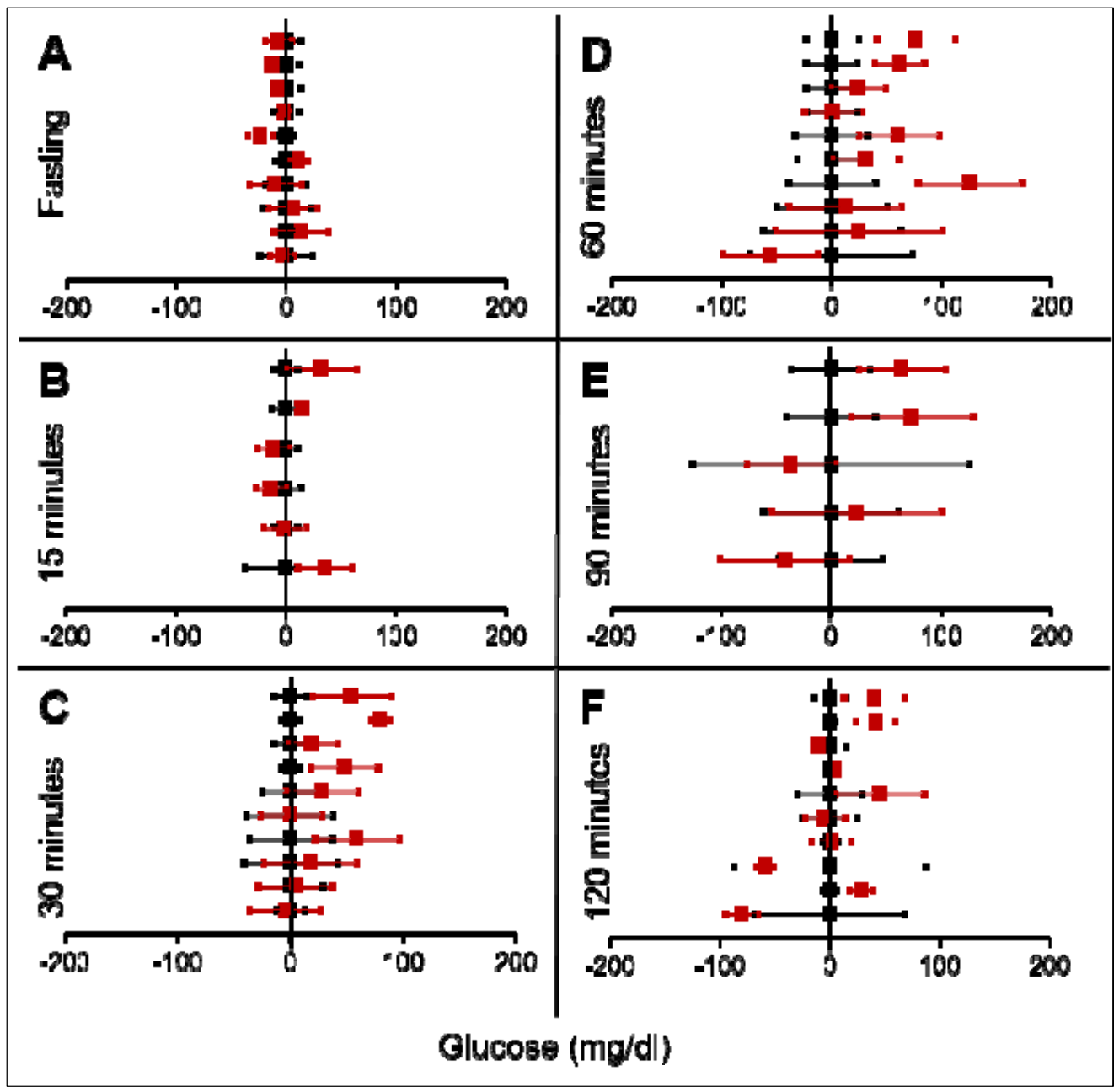


bioRxiv preprint doi: https://doi org/101101/553016 this version posted July 16 2019. The copyright holder for this preprint (which was not certified by peer review) is the author/funder, who has granted bioRxiv a license to display the preprint in perpetuity. It is made available under aCC-BY-ND 4.0 International license.

169 Figure 3: Results with LIRKO represented as in figure 1. Note that inconsistent with classical belief, liver

170 specific insulin receptor knockout does not show significant effect on fasting glucose in any of the experiments.

171 On the other hand post load glucose is consistently higher.

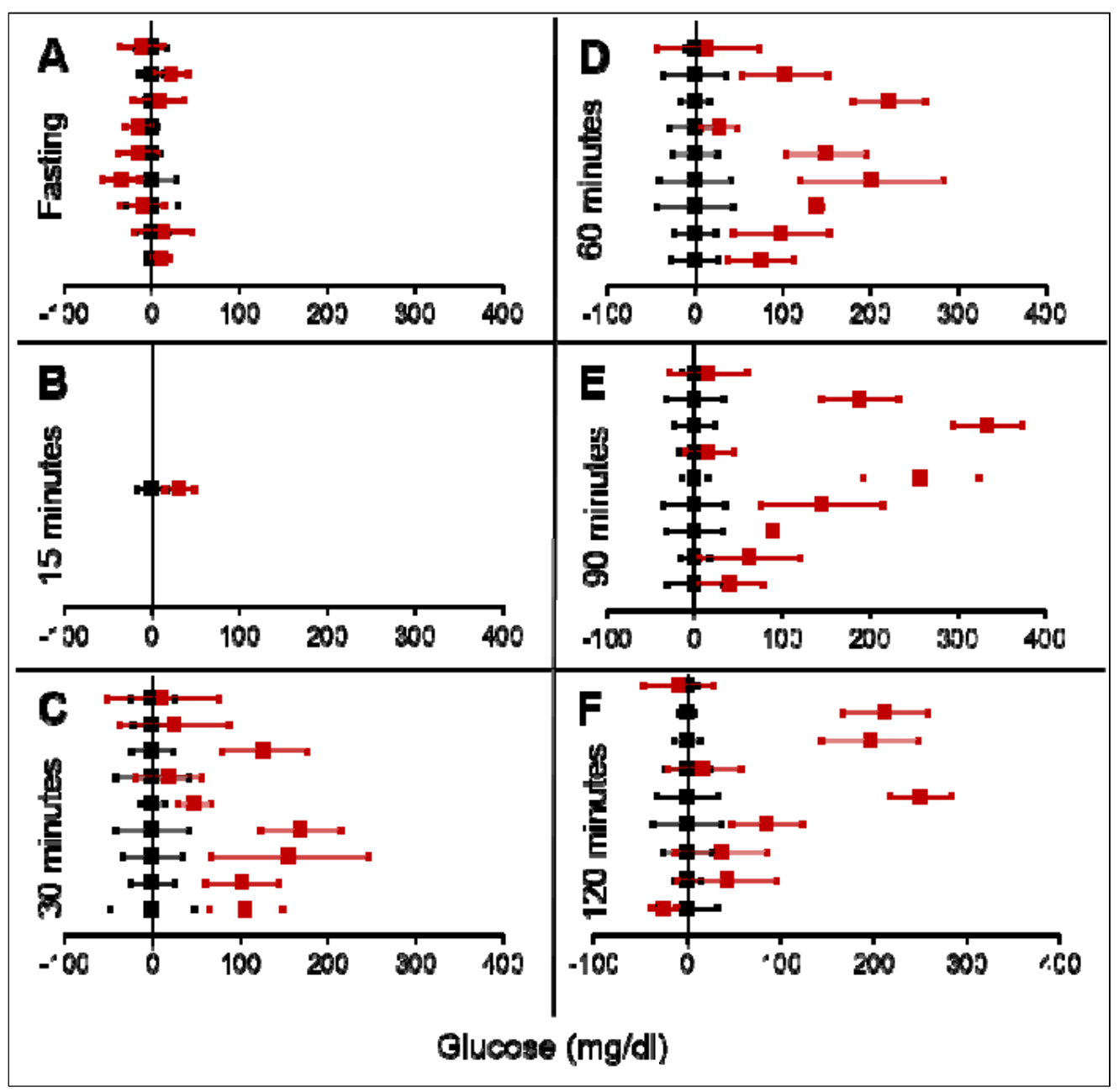


175 Figure 4: Results with $\boldsymbol{\beta}$ IRKO represented as in figure 1. Note that fasting glucose does not differ from the

176 control in any of the experiments.

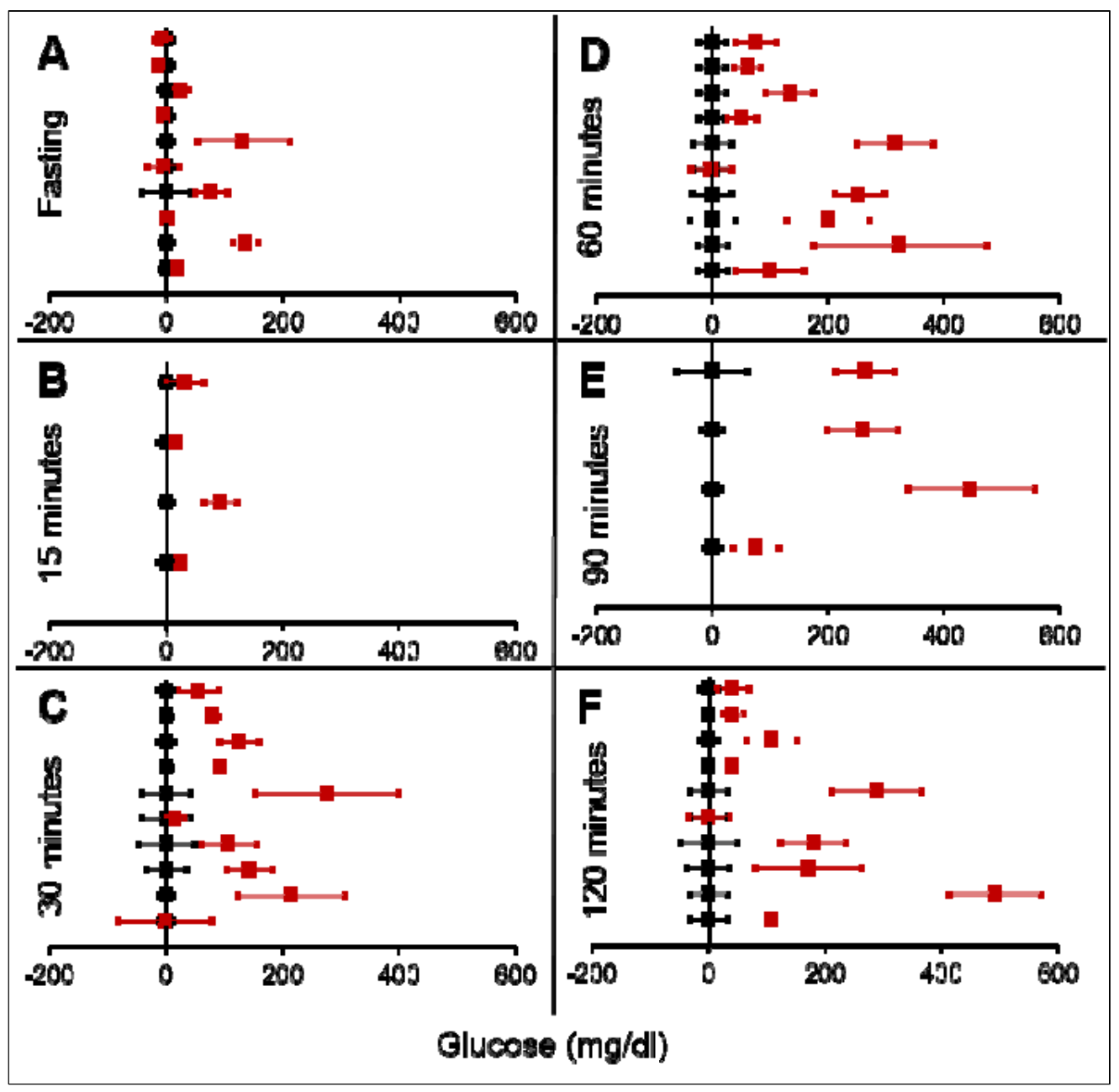

\section{Systematic review and meta-analysis of insulin increase and insulin suppression}

182 The insulin receptor knockout experiments are based on the assumption that the main action

of insulin is through the specific receptors. It can be argued that insulin acts through other 
alter plasma glucose immediately on administration but this is not a steady-state response. If insulin levels can be raised or lowered and sustained long enough to reach a steady state, the effect of insulin on glucose in a steady-state can be studied. If insulin affects steady-state glucose, a sustained rise in insulin will result into a sustained lower steady-state glucose level. Conversely a sustained suppression of insulin would lead to higher steady-state glucose. We studied published literature for experiments where a stable and sustained increase or decrease in insulin was achieved and then the effect on fasting glucose and GTT studied.

\subsection{Methods}

\subsubsection{Increase in insulin}

The model of choice for a sustained increase in insulin levels is a knock out or inhibition of the insulin degrading enzyme (IDE). An interplay between insulin secretion and insulin degradation maintains the level of insulin in plasma (53-56). Plasma insulin has a half-life of 4 to 9 minutes $(57,58)$ and it is degraded predominantly by the insulin degrading enzyme (IDE) $(54,57)$. Inhibition of IDE has been considered as a therapeutic option for type 2 diabetes with limited success $(59,60)$. We performed a systematic literature review to find out experiments in which IDE was inhibited to obtain a sustained high plasma insulin level and, in such animals, GTT was performed (table 3).

\subsubsection{Decrease in insulin}

We performed a systematic literature review for experiments in which there was sustained suppression of insulin production. Two insulin suppressing agents have been repeatedly used to lower insulin production in rodent models as well as in humans. 
(i) Diazoxide (DZX): Diazoxide is a potassium channel activator which causes reduction in insulin secretion by the $\beta$-cells by keeping the cells in a hyperpolarized state by opening the channel (61). It has been used as a drug to modulate insulin secretion for research and therapeutic purposes (62).

(ii) Octreotide (OCT): Octreotide is a somatostatin analogue which inhibits insulin and growth hormone. It has been used to reduce insulin secretion in vitro and in vivo (63).

219 We searched the literature systematically for studies where the insulin levels have been suppressed by other methods.

\subsection{Results}

\subsubsection{Increase in insulin by suppression of IDE}

Table 3: Systematic literature review for studies on insulin degrading enzyme inhibition/knockout (metaanalysis 2).

\begin{tabular}{|l|l|}
\hline Meta-analysis $\mathbf{~} \rightarrow$ & Insulin degrading enzyme \\
\hline Key word used for the first search on the & "insulin degrading enzyme" \\
PubMed/MEDLINE data-base & \\
\hline Number of hits in the first search & \\
\hline Inclusion criteria for primary screening & Studies showing experiments with inhibition of IDE \\
& and GTT \\
\hline Number of papers shortlisted based on & \\
\hline
\end{tabular}




\begin{tabular}{|l|l|}
\hline primary screening & \\
\hline Inclusion criteria for secondary screening & Study showed experiments with IDE inhibition, had \\
fasting and post-glucose load readings of control \\
and IDE inhibition \\
\hline Number of papers shortlisted based on & \\
screening the full-text and back & \\
referencing (data for the meta-analysis & \\
extracted from these papers) & \\
\hline List of the studies used in the final meta- & \\
analysis (all were rodent studies; reference & \\
numbers given here)
\end{tabular}

Table 4: Comparison between steady-state (fasting) and perturbed-state (post glucose load) of control and IDE suppression.

\begin{tabular}{|c|c|c|c|c|c|c|}
\hline & $\begin{array}{c}\text { Total } \\
\text { experiments }\end{array}$ & $\mathbf{T}>\mathbf{C}$ & $\mathbf{T}<\mathbf{C}$ & $\begin{array}{c}p \text { using } \\
\text { chi } \\
\text { square }\end{array}$ & $\begin{array}{c}\text { T > C } \\
\text { individually } \\
\text { significant }\end{array}$ & $\begin{array}{c}\mathrm{T}<\mathrm{C} \text { individually } \\
\text { significant }\end{array}$ \\
\hline Fasting & 18 & 12 & 6 & 0.157 & 0 & 1 \\
\hline 15 minutes & 14 & 7 & 7 & 0.999 & 3 & 5 \\
\hline 30 minutes & 18 & 10 & 8 & 0.637 & 5 & 2 \\
\hline 60 minutes & 18 & 11 & 7 & 0.346 & 5 & 1 \\
\hline 90 minutes & 16 & 13 & 3 & $0.012 *$ & 4 & 0 \\
\hline 120 minutes & 18 & 15 & 2 & $0.002 *$ & 2 & 1 \\
\hline
\end{tabular}

Figure 5: Results with IDE inhibition represented as in figure 1. Note that fasting glucose does not differ

233 significantly from the control. At 90 and 120 minutes the trend is higher mean glucose than control which is

234 contrary to the expectation in an experiment with sustainable rise in insulin. 

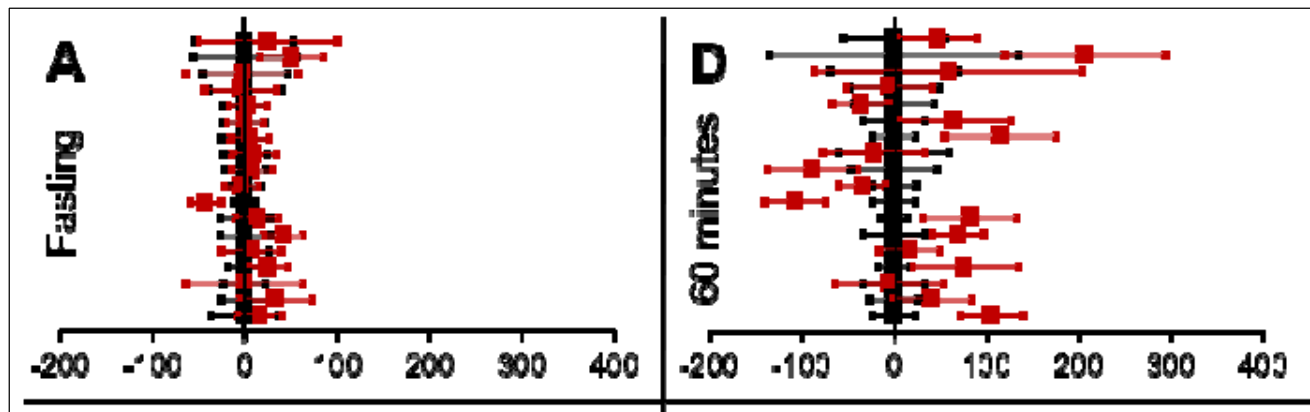

237 We found 6 publications that described 18 experiments that allowed comparison of GTT

238 between raised insulin groups and control group (table 2 of supplementary information 1).

239 Meta-analysis revealed no significant difference in the fasting glucose. In only one out of 18

240 experiments the treatment group had lower fasting glucose than the control. During the GTT

241 curve, at 90 and 120 minutes the difference between treatment and control were significant

242 but in the opposite direction of the expectation. While rise in insulin level should reduce

243 plasma glucose, it increased in 15 out of 18 studies, two of which were individually

244 significant and the difference was significant in non-parametric meta-analysis. Across all

245 time points along the GTT, the plasma glucose in the treated group was greater than the 
control group in majority of the experiments. Thus, in this class of experiments increasing

insulin failed to reduce glucose at the steady-state as well as post glucose load.

248

\subsection{2: Decrease in insulin: Suppression by diazoxide or octreotide}

Table 5: Systematic literature review for studies on insulin suppression with diazoxide and octreotide

\begin{tabular}{|c|c|c|}
\hline $\begin{array}{l}\text { Meta-analyses } 3 \text { and } 4 \rightarrow \\
\text { Task performed } \downarrow\end{array}$ & Diazoxide & Octreotide \\
\hline $\begin{array}{l}\text { Key word used for the first } \\
\text { search on the } \\
\text { PubMed/MEDLINE data- } \\
\text { base }\end{array}$ & $\begin{array}{l}\text { "diazoxide and diabetes"; } \\
\text { "insulin suppression" }\end{array}$ & $\begin{array}{l}\text { "octreotide and diabetes"; } \\
\text { "insulin suppression }\end{array}$ \\
\hline $\begin{array}{l}\text { Number of hits in the first } \\
\text { search }\end{array}$ & 1043 & 1202 \\
\hline $\begin{array}{l}\text { Inclusion criteria for } \\
\text { primary screening }\end{array}$ & $\begin{array}{l}\text { Study shows stable insulin } \\
\text { suppression using diazoxide and } \\
\text { a GTT has been performed after } \\
\text { insulin suppression. }\end{array}$ & $\begin{array}{l}\text { Study shows stable insulin } \\
\text { suppression using octreotide } \\
\text { and a GTT has been } \\
\text { performed after insulin } \\
\text { suppression. }\end{array}$ \\
\hline $\begin{array}{l}\text { Papers shortlisted based on } \\
\text { primary screening }\end{array}$ & 239 & 289 \\
\hline $\begin{array}{l}\text { Inclusion criteria for } \\
\text { secondary screening }\end{array}$ & $\begin{array}{l}\text { Study showed similarities in the } \\
\text { concentration of diazoxide used; } \\
\text { and had fasting and post glucose } \\
\text { bolus readings of the control and }\end{array}$ & $\begin{array}{l}\text { Study showed similarities in } \\
\text { the concentration of } \\
\text { octreotide used; and had } \\
\text { fasting and post glucose bolus }\end{array}$ \\
\hline
\end{tabular}




\begin{tabular}{|l|l|l|}
\hline $\begin{array}{l}\text { Papers shortlisted based on } \\
\text { screening the full-text and } \\
\text { back referencing (data for } \\
\text { the meta-analyses extracted } \\
\text { from these papers) }\end{array}$ & Rodent studies (2) & readings of the control and \\
octreotide subjects \\
\hline $\begin{array}{l}\text { List of the studies used in } \\
\text { the final meta-analysis }\end{array}$ & $(69-76)$ & Human studies (10) \\
\hline Human studies (reference & $(69,72-76)$ & $(77-86)$ \\
numbers given here) & & \\
\hline Rodent studies (reference \\
numbers given here)
\end{tabular}


254 Table 6: Comparison between steady-state(fasting) and perturbed-state (post glucose load) of control and

255 insulin suppression.

\begin{tabular}{|c|c|c|c|c|c|c|}
\hline & \begin{tabular}{|c|} 
Total \\
studies
\end{tabular} & $\mathbf{T}>\mathbf{C}$ & $\mathbf{T}<\mathbf{C}$ & $\begin{array}{c}p \text { using } \\
\text { chi } \\
\text { square }\end{array}$ & $\begin{array}{c}\mathbf{T}>\mathbf{C} \text { individually } \\
\text { significant }\end{array}$ & $\begin{array}{c}\mathrm{T}<\mathrm{C} \text { individually } \\
\text { significant }\end{array}$ \\
\hline \multicolumn{7}{|c|}{ Diazoxide treatment } \\
\hline Fasting & 14 & 10 & 3 & 0.052 & 5 & 0 \\
\hline 15 minutes & 7 & 6 & 1 & 0.059 & 1 & 1 \\
\hline 30 minutes & 12 & 10 & 2 & $0.021 *$ & 2 & 1 \\
\hline 60 minutes & 13 & 9 & 4 & 0.166 & 4 & 2 \\
\hline 90 minutes & 3 & 3 & 0 & 0.083 & 2 & 0 \\
\hline 120 minutes & 14 & 10 & 3 & 0.052 & 6 & 1 \\
\hline \multicolumn{7}{|c|}{ Octreotide treatment } \\
\hline Fasting & 15 & 6 & 7 & 0.781 & 0 & 0 \\
\hline 30 minutes & 14 & 4 & 10 & 0.108 & 0 & 2 \\
\hline 60 minutes & 14 & 4 & 10 & 0.108 & 2 & 1 \\
\hline 90 minutes & 13 & 5 & 8 & 0.405 & 1 & 0 \\
\hline 120 minutes & 15 & 7 & 8 & 0.797 & 1 & 1 \\
\hline
\end{tabular}

257 We found 8 papers describing 14 experiments for diazoxide treatment and 10 papers with 15 experiments for octreotide treatment (tables 3 and 4 from supplementary information 1 respectively). It can be seen from table 6 and fig 6 that for both of the insulin suppressing agents, suppression of insulin did not result into increased fasting glucose. Further at 120 minutes post glucose load there was a marginally significant rise in glucose in the insulin suppressed group as compared to control group. This demonstrates that pharmacological 
suppression of insulin was unable to raise plasma glucose level in a fasting steady state.

264 There was inconsistent but significant rise post glucose load.

265 Figure 6: Results with Insulin suppression with Diazoxide and Octreotide represented as in figure 1. Note 266 the inconsistencies across studies.

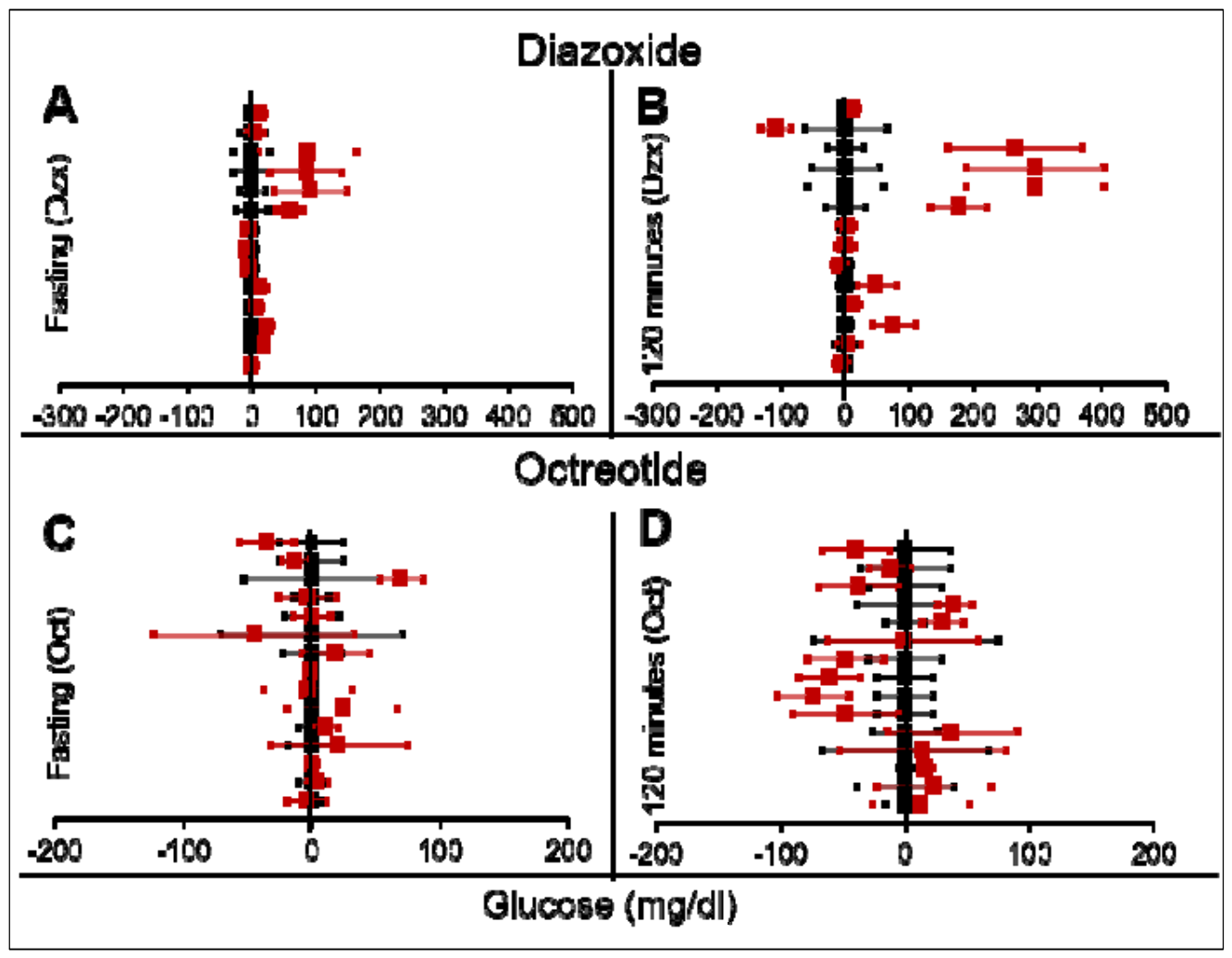

We found more means of insulin suppression in which GTT after suppression was reported,

270 but there were not many published replications of the experiments coming independently

271 from different research groups. Therefore meta-analysis was not warranted. We briefly

272 review their results here.

274 Suppression by Protein restriction: Dietary protein deprivation is another method of insulin

275 suppression. This also led to a decrease in plasma insulin levels; however fasting glucose

276 levels did not increase (87). 
278 Suppression by insulin siRNA: Transgenic mice for insulin-siRNA along with IDE

279 overexpression, showed decreased levels of insulin. Again the fasting glucose levels

280 remained normal while there was a change in glucose tolerance curve (figure 7) (88). The

281 curves in figure 7 are typical of insulin receptor knockout or insulin suppression experiments

282 where, in individuals with impaired insulin signalling the glucose peak is higher which

283 returns to steady-state much later than the controls, but the fasting steady-state level is not

284 different.

285

286 Figure 7: Intra peritoneal glucose tolerance test (panel A and B). Fasting glucose levels in both the siRNA

287 treated and untreated group remain unaltered in male and female mice. 15 minutes after the glucose injection,

288 the treated mice show higher glucose levels relative to the untreated mice and this effect is seen throughout till

289120 minutes. Figure redrawn from data by (88).

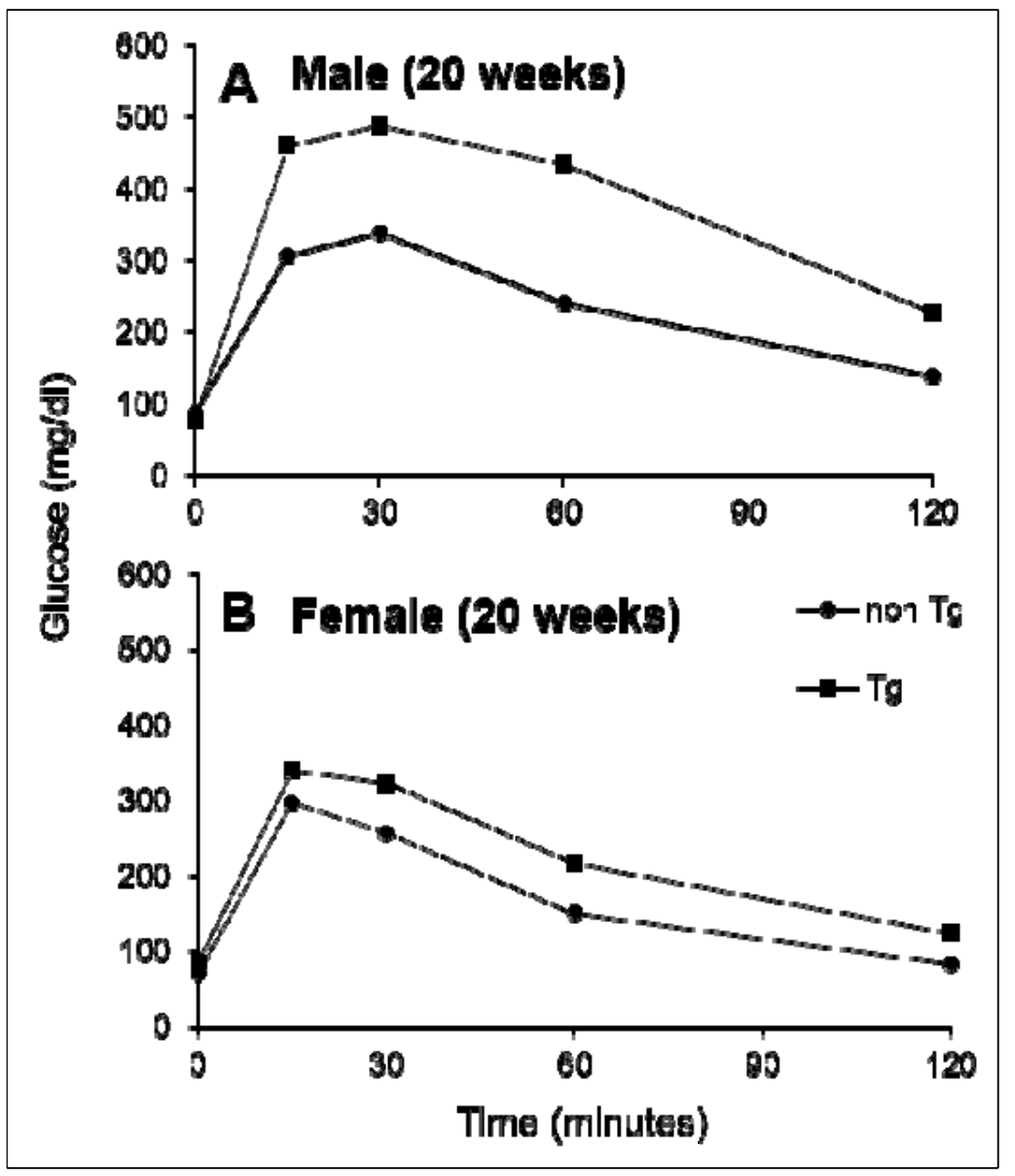


Suppression of insulin by partial gene ablation: In rodents, there are two insulin genes Ins 1 and Ins2 (89). A double knockout of both the genes results in death, but ablation of either of the genes does not alter the glucose tolerance significantly suggesting redundancy (90). There are studies in which one gene is completely knocked out and the other one is a heterozygote (90-94). Reduced insulin gene dosage did not consistently result into fasting hyperglycemia in these studies although it offered protection against some of the effects of hyperinsulinemia.

\section{Steady-state versus post feeding glucose in STZ rats}

Streptozotocin (STZ) induced diabetes is a popular model of rodent diabetes. STZ acts by specifically destroying the insulin producing $\beta$ cells of the pancreatic islets. A low dose of STZ that destroys a substantial population of $\beta$ cells but does not lead to total destruction of their population is often perceived as a good model for T2D, whereas a high dose of STZ that destroys the $\beta$ cell population almost entirely is perceived as a model of T1D. We searched literature to look for studies that carefully differentiated between steady-state glucose from post load glucose in STZ models but did not find any studies that make this distinction clear. Therefore, we designed and conducted experiments to differentially study the steady-state and perturbed-state glucose levels in rats treated with STZ.

\subsection{Experimental methods}

\subsubsection{Animal model and conditions}

The experiments performed on Sprague Dawley (SD) rats had been approved by the Institutional Animal Ethics Committee at IISER, Pune (Protocol Number IISER/IAEC/201602/006) constituted by CPCSEA, Govt. of India. All the rats were housed in a facility with a temperature of $23 \pm 2^{\circ} \mathrm{C}$ and a 12-hour light/dark cycle with standard rat chow and water 
available ad libitum. The bedding of the cages was changed every three days.

\subsubsection{STZ treatment for insulin suppression}

Male, SD rats weighing 180-200 g were injected with STZ at $50 \mathrm{mg} / \mathrm{kg}$ body weight. The

STZ was dissolved in Citrate Buffer (Citric Acid: 0.1M and Sodium Citrate: 0.1M). Injection

of citrate buffer alone was used as control.

\subsubsection{Fasting and post-feeding glucose in 12 day follow up}

324 Three days after the STZ injection, the rats were fasted for 16 hours and glucose was

measured using the hand held Accu-Chek Glucometer. The rats were then given 40 grams of

Standard Chow for 8 hours. Food was weighed and post-meal glucose was measured after

three hours. The protocol was repeated for 12 days and body weight, food weight and glucose readings were taken daily. 12 animals per group were used for this experiment.

\subsubsection{Duration of fasting}

An experiment was also performed to see how much time was required to reach a steady-state

of glucose after removal of food. The food was removed from the STZ and Control animals after ad libitum availability and glucose readings were taken after 3 hours, 6 hours, 9 hours, 12 hours and 16 hours. After a recovery of three days, glucose levels were measured only at 16 hours after removing the food. 9 STZ treated animals and 10 Control animals (injected with citrate buffer) were used for this experiment.

Figure 8: Treatment of SD rats with STZ. (A): The 16-hour fasting and post-meal glucose values of treated 
bioRxiv preprint doi: https://doi org/10.1101/553016: this version posted July 16,2019. The copyright holder for this preprint (which was not certified by peer review) is the author/funder, who has granted bioRxiv a license to display the preprint in perpetuity. It is made available under aCC-BY-ND 4.0 International license.

(B) Time course of glucose during 16 hours fasting. X axis represents the time after removal of food when the glucose readings are taken and Y axis represent the glucose levels. The grey band represents the upper and lower bounds of $95 \% \mathrm{CI}$ of the control group with the mean glucose values represented by filled circles. Filled squares represent individuals that showed a monotonic decrease in glucose levels. In three animals the glucose levels reduced at or below the control levels and in two others they showed a continued monotonic decrease but did not reach the normal level in 16 hours. Filled triangles with dotted lines represent the individual time courses of the three STZ treated rats which showed some indications of stabilizing at a steady-state above the normal.
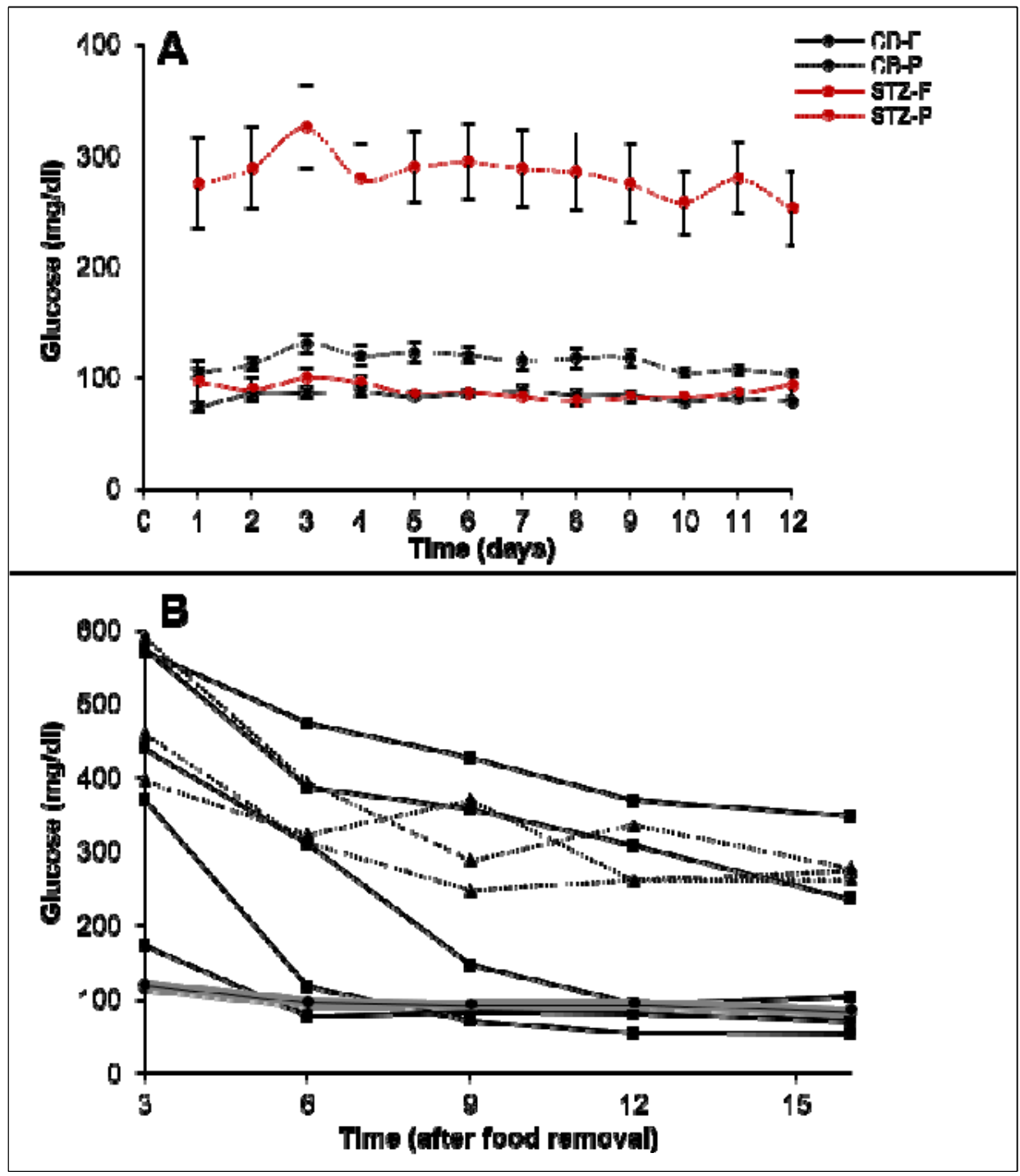

\subsection{Results}

Among the STZ treated rats, all the animals showed significantly higher post load glucose than the control group on all the 12 days sampled. However, in 10 out of the 12 days the 16- 
353 hour fasting glucose was not significantly different from the control although the variance

354 was substantially greater than that of the control (figure 8).

356 A close look at the time course of fasting in the two groups revealed that in 4 out of 9 STZ

357 animals the glucose levels reached the normal range but with substantial delay as compared

358 to control animals. In two more animals the levels did not reach the normal range till 16 hours

359 but a monotonic decrease continued throughout the period, indicating that their blood glucose

360 may not have reached a steady-state in 16 hours. Only in 3 animals the 16-hour glucose was

361 higher than the control range with some indications of stabilizing at a higher level. In the time

362 course experiment, the animals are handled frequently leading to some unavoidable stress. In

363 the 12 day follow up plasma glucose is estimated only after 16 hours and here there is no

364 significant difference in the control and STZ animals on 10 out of 12 days. Furthermore the

365 individuals that showed higher 16 hour fasting glucose did not do so consistently. In the 12

366 days follow up, the distribution of 16-hour fasting glucose was typically skewed with one or

367 two outliers having high glucose levels. Interestingly the outliers were not the same animals

368 every day. There was considerable day to day variation in individuals and averaged over the

36912 days, none of the STZ animals showed significantly higher fasting glucose than the

370 controls although they consistently showed higher post feeding glucose.

371 Thus, these experiments show on the one hand that STZ treatment failed to increase steady

372 state glucose levels significantly and consistently. On the other, the STZ animals took

373 substantially longer and rather unpredictable time to reach a steady-state and even at 16-hours

374 of fasting, all individuals need not have attained a steady state. These results warrant caution

375 against considering fixed hours fasting glucose as steady-state glucose in experimental or

376 epidemiological data. While in healthy individuals it is well established that following

377 glucose load a steady-state is regained in about two hours, it is possible that in experimental 
400

impairment of insulin signalling or in clinical diabetes, plasma glucose takes substantially longer time to reach a steady-state and overnight fasting need not represent a steady-state in all cases.

\section{Theoretical and mathematical considerations}

In this approach we elaborate on the theoretical underpinnings of insulin-glucose relationship. We also explore possible explanations for the unexpectedly consistent failure of experimental insulin signal impairment to alter steady-state glucose level. Simultaneously we make differential predictions from alternative homeostasis models that can be tested in human epidemiological data.

\subsection{Choice of Models for glucose homeostasis}

The fasting state has been generally accepted to be a steady-state for glucose concentration for several reasons. In a given healthy individual the fasting glucose levels are stable in time $(95,96)$. The post-meal peak of glucose and insulin returns to the fasting level within a few hours and remains stable over a long time. The fasting state is considered and modelled as a steady-state by the widely used HOMA model $(28,29)$. Classically the negative feedback loops are assumed to work through insulin and insulin is taken as a determinant of steadystate glucose level. Most popular models of glucose homeostasis work on this assumption although non-steady-state models of insulin resistance exist (97).

A critical question in glucose homeostasis is whether the fasting steady-state glucose level is a consequential balance between glucose production and glucose utilization rates (consequential steady-state CSS) or whether there is a target glucose level that is maintained by sensing and correcting any changes in it (targeted steady-state TSS). The difference in the two can be visualized by the tank water level analogy (fig 9). If a tank has an input tap 
releasing water in it at a constant rate and has an outlet at the bottom through which water escapes proportionate to the pressure of the water column, a steady-state is invariably reached. The steady-state level is decided by the rate of intake and the size of the outlet. This is a CSS which will change with any change in the size/capacity of the input or the outlet tap. In contrast to CSS, in a TSS there is a desired water level and sensors are placed above and below the desired level such that when the level goes below the lower sensor the input is switched on or its rate increased and/or output switched off or its rate decreased.

Figure 9: The consequential steady-state (CSS) (A) and targeted steady-state (TSS) (B) models of homeostasis illustrated with a tank water level analogy. In CSS a change in the size of inlet or outlet tap, analogous to insulin sensitivity can change the steady-state level. In a TSS model, a change in the tap size will alter the time required to reach a steady-state but will not change the steady-state level.

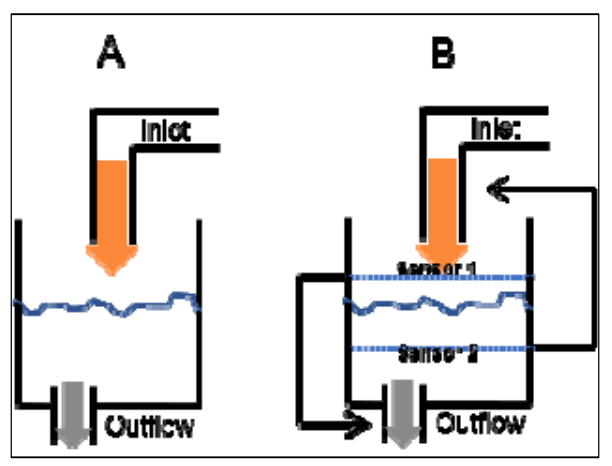

In glucose homeostasis, in a fasting state, liver glucose production is analogous to the inlet tap and tissue glucose uptake analogous to the size of the outlet, both being a function of insulin signalling. Most models of glucose regulation assume CSS (28,29,58,98-100) (97). It has not been critically examined whether CSS or TSS describes glucose homeostasis more appropriately. This is important because if TSS model is appropriate, insulin resistance and relative insulin deficiency will not result into altered steady-state glucose levels although the time required for reaching a steady-state after perturbation might change. If CSS model is appropriate, insulin resistance or altered insulin levels are bound to change fasting glucose levels. The failure of insulin receptor knockouts and insulin suppression experiments to alter 
425 the fasting steady state, along with the delay in reaching the steady-state indicates that TSS

426 model is likely to describe glucose homeostasis more appropriately. The TSS model requires

427 mechanisms of sensing any departure from the targeted steady state. Such mechanisms are

428 not known in peripheral systems but glucose sensing neurons are certainly known to be

429 present in the brain. Therefore, if TSS is a more appropriate model, the CNS mechanisms are

430 likely to be central to glucose homeostasis, particularly in determining the steady-state levels;

431 whereas insulin signalling would play a role in determining the rate at which a steady-state is

432 reached after perturbation.

434 It is possible to make other testable predictions of TSS and CSS models. In the normal

435 healthy individual, increased glucose utilization is expected to decrease fasting glucose levels

436 by the CSS model but not by the TSS model. Human experiments have shown that sustained

437 exercise does not reduce plasma glucose, in fact it might increase (101). In order to match

438 with experimental data, CSS based models of glucose dynamics during exercise need to

439 include additional terms which involve neuronal mechanisms such as direct stimulation of

440 liver glucose production in response to exercise through sympathetic route (102). This brings

441 the model close to a TSS model. If TSS model describes glucose homeostasis more

442 appropriately, reduced insulin signalling is not expected to change steady-state glucose but

443 only alter the time course to reach a steady state.

445 The mechanism of attaining a hyperinsulinemic normoglycemic prediabetic state is different

446 by the CSS and TSS models. By the classical CSS based pathway, obesity induced insulin

447 resistance is believed to be primary. The insulin resistance reduces glucose uptake and the

448 excess glucose triggers a compensatory insulin response. The resultant hyperinsulinemia

449 compensates for insulin resistance keeping the fasting glucose levels normal. Detailed 
analysis of the model and matching its prediction with empirical data has refuted this model (30). One of the intuitively appealing reasons for this refutation is that after the heightened insulin levels normalize glucose, there is no reason why insulin levels remain high. Therefore, a steady-state with hyperinsulinemia and normoglycemia is impossible by the CSS model but it exists in a prediabetic state. If a "compensatory" insulin response is mediated by glucose, one would expect a positive correlation between fasting glucose (FG) and fasting insulin (FI) and no correlation between insulin resistance and $\beta$ cell responsiveness.

By the TSS model, on the other hand, compensatory response is possible in either way. Primary insulin resistance may increase the glucose levels transiently, but when glucose sensing mechanisms detect the change a compensatory response can be operational. By this mechanism a hyperinsulinemic normoglycemic state is possible. Alternatively, primary hyperinsulinemia $(7,103-105)$ can also be compensated by increased insulin resistance by hitting the lower level of sensing which would trigger compensatory insulin resistance. Even in this case a hyperinsulinemic normoglycemic state is possible. Both glucose sensing neurons and neuronal regulation of insulin release and liver glucose production are well known. In the compensatory response mediated by TSS pathways there need not be a correlation between fasting insulin and fasting glucose, but insulin resistance and $\beta$ cell response would be correlated.

Also using a simple CSS model (see supplementary information 2 for details), simulations show that the correlation coefficient and regression slope in the insulin-glucose relationship would remain the same in the fasting as well as post-meal state although the range of glucose and insulin levels will be different. On the other hand, in a TSS model the post-meal glucose and insulin levels are expected to be correlated but the steady-state levels may not. We test these predictions by the alternative models using human epidemiological data below. 
476 We argued above that since on impairment of insulin signalling, the time required to reach a

477 steady-state can be substantially longer, overnight fasting may not ensure a steady-state in all

478 individuals. Fasting hyperglycaemia in T2D can have two alternative (but not mutually

479 exclusive) causes. Either it represents the failure to reach a steady-state in the specified

480 fasting period, or it is because of mechanisms other than reduced insulin action. The TSS

481 model can make differential predictions from the two alternative causes since it predicts a

482 positive correlation between plasma glucose and plasma insulin in the post-meal state but loss

483 of this correlation on reaching a steady state. In population data, if some individuals have

484 reached a steady-state but a few others haven't we would expect a correlation significantly

485 weaker than the post-meal correlation. These predictions can be tested in epidemiological

486 data.

487

488

6. Analysis of insulin glucose relationship in steady and perturbed-state in human data:

Epidemiological inquiry

490 Here we use human epidemiological data to test the correlational predictions made by the

491 CSS versus TSS models of glucose homeostasis. 
492

493

494

495

\subsection{Methods}

\subsubsection{Epidemiological data}

The three data sets used here come from two different studies: (i) Coronary Risk of Insulin Sensitivity in Indian Subjects (CRISIS) study, Pune, India (106) and (ii) Newcastle Heart Project (NHP), UK (107). Data from the latter is divided into two groups as the subjects belong to different ethnicities namely European white and south Asian and we will prefer to analyse the two groups separately since certain ethnic differences are likely to be present in the tendency to develop metabolic syndrome $(108,109)$. Hence all the comparison of predictions with the data has been done independently for the three data sets. All the studies are population surveys that include non-diabetic (fasting glucose values less than $110 \mathrm{mg} / \mathrm{dl}$ ) and diabetic individuals (fasting glucose values above $110 \mathrm{mg} / \mathrm{dl}$ ) and the clinical history, morphometric parameters, glucose and insulin during fasting and oral glucose tolerance test (OGTT) of the subjects were recorded. In the analysis below we included only the nondiabetic groups in which the homeostatic mechanism can be assumed to be intact and therefore any hypothesis about it can be tested. Most of the individuals in the diabetic group would be under different drug regime affecting glucose-insulin dynamics in different ways and therefore we exclude that group for the analysis.

\subsubsection{Analysis}

Linear regression and correlation were used to compare the glucose-insulin relationship in steady-state (fasting) versus perturbed-state (post glucose load) in the three data sets along with the relationships between HOMA-IR and HOMA- $\beta$ derived from the fasting data. 
515

516 In all the three data sets there was weak $\left(\mathrm{R}^{2}\right.$ range 0.017 to 0.057$)$ but significant correlation

517 between fasting glucose (FG) and fasting insulin (FI) and strong correlation between HOMA-

518 IR and HOMA- $\beta\left(\mathrm{R}^{2}\right.$ range 0.20 to 0.83 ) (figure 10 ).

Figure 10: The Fasting Glucose-Fasting Insulin, Post-meal Glucose-post-meal Insulin and HOMA-IR HOMA- $\beta$ scatter plots in non-diabetic populations in the three data sets. The FG-FI correlation is weak as compared to post-meal correlation. The HOMA-IR and HOMA- $\beta$ correlations are very strong in all the three data sets, which is not expected by the classical insulin resistance theory.

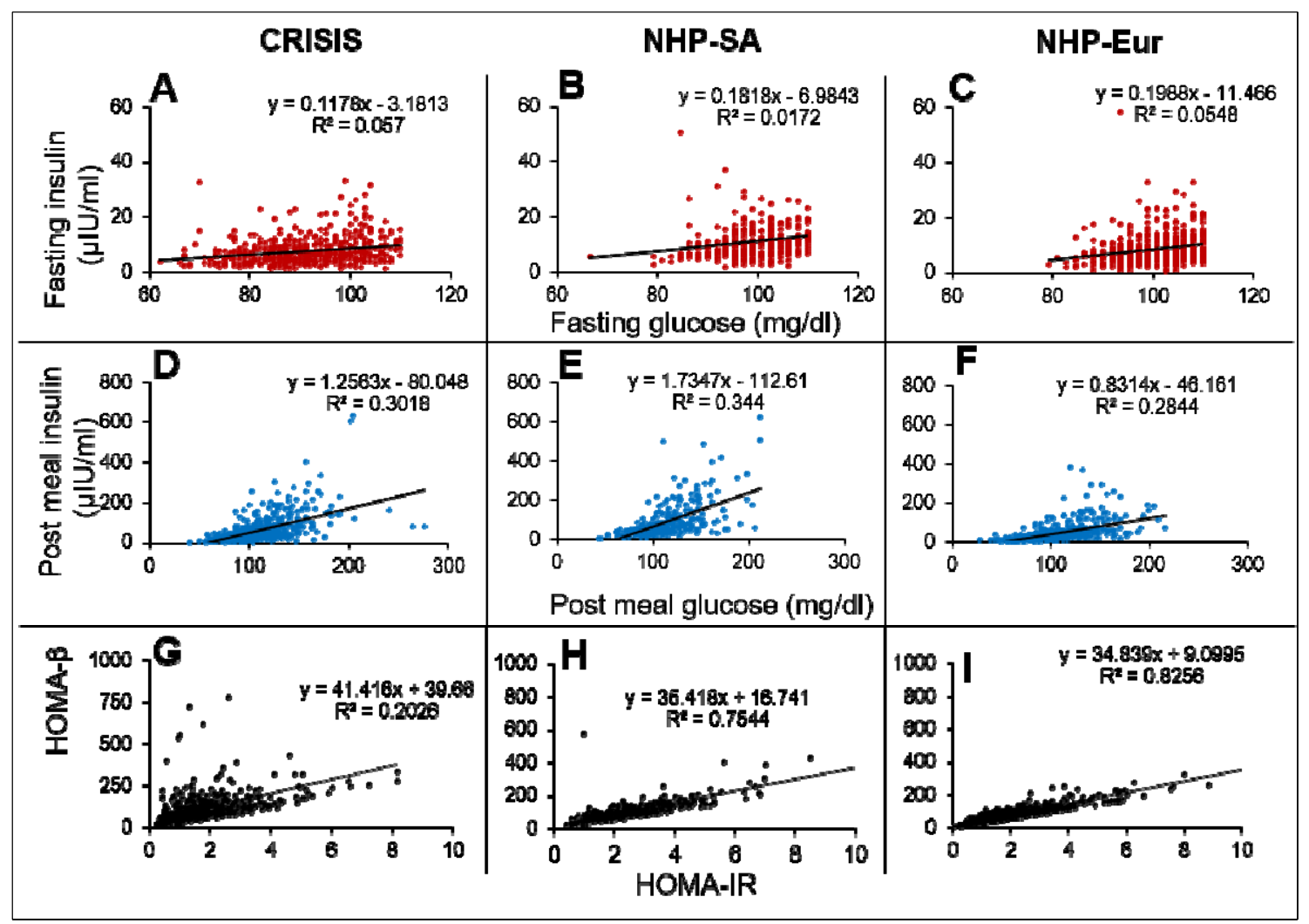

526 It was seen in all three data sets that the correlation coefficients for glucose and insulin were

527 an order of magnitude higher in the post-meal cross sectional data than in the fasting state

528 (Table 7 and fig 10). Also, the regression slopes in the post-meal data were substantially

529 different from fasting data unlike what is expected by the CSS model (Supplementary 
530 information 2). By both the sets of predictions the CSS model predictions are rejected. The

531 HOMA-IR HOMA- $\beta$ correlation, as well as the difference between the regression correlation

532 parameters between fasting and post-meal data are compatible with predictions of the TSS

533 model. However, although weak, there is significant correlation between FG and FI unlike

534 what may be expected by a steady-state TSS model. This incompatibility is not sufficient to

535 falsify the TSS model since the failure of a small proportion of individuals to have reached a

536 steady-state at overnight fasting is sufficient to explain the weak correlation. It is also likely

537 that the assumption of fasting may not be true for the entire sample. Even if a small number

538 of individuals do not comply with the overnight fasting instructions, a positive correlation can

539 result and this possibility is extremely difficult to exclude in human data.

540 The support of TSS model over CSS model is important because it accounts for the failure of

541 impairment of insulin signalling to alter fasting glucose but increase only post load glucose.

542 Table 7: Correlation and regression parameters of glucose-insulin relationship at steady and perturbed states.

\begin{tabular}{|c|c|c|c|c|c|c|}
\hline \multirow[b]{2}{*}{$\begin{array}{l}\text { Parameter } \rightarrow \\
\text { Data set } \downarrow\end{array}$} & \multicolumn{3}{|c|}{ Steady-state(fasting) } & \multicolumn{3}{|c|}{$\begin{array}{c}\text { Perturbed-state } \\
\text { (2 hours post glucose bolus) }\end{array}$} \\
\hline & $\begin{array}{l}\text { R-squared } \\
\text { (variance } \\
\text { explained) }\end{array}$ & p value & $\begin{array}{c}\text { Slope }(95 \% \\
\text { CI })\end{array}$ & $\begin{array}{l}\text { R-squared } \\
\text { (variance } \\
\text { explained) }\end{array}$ & p value & $\begin{array}{c}\text { Slope }(95 \% \\
\text { CI })\end{array}$ \\
\hline $\begin{array}{l}\text { CRISIS } \\
(\mathrm{N}=522)\end{array}$ & $0.0570(5.7 \%)$ & $<0.0001$ & $\begin{array}{c}0.1178 \\
(0.0765 \text { to } \\
0.1591)\end{array}$ & $\begin{array}{c}0.3018 \\
(30.18 \%)\end{array}$ & $<0.0001$ & $\begin{array}{c}1.2563 \\
(1.0917 \text { to } \\
1.4209)\end{array}$ \\
\hline $\begin{array}{l}\text { NHP-South Asian } \\
(\mathrm{N}=310)\end{array}$ & $\begin{array}{l}0.0172 \\
(1.72 \%)\end{array}$ & 0.021 & $\begin{array}{c}0.1818 \\
(0.0279 \text { to } \\
0.3356)\end{array}$ & $0.344(34.4 \%)$ & $<0.0001$ & $\begin{array}{c}1.7347 \\
(1.4661 \text { to } \\
2.0033)\end{array}$ \\
\hline $\begin{array}{l}\text { NHP-European } \\
(\mathrm{N}=574)\end{array}$ & $\begin{array}{l}0.0548 \\
(5.48 \%)\end{array}$ & $<0.0001$ & $\begin{array}{c}0.1988(0.131 \\
\text { to } 0.2666)\end{array}$ & $\begin{array}{c}0.2844 \\
(28.44 \%)\end{array}$ & $<0.0001$ & $\begin{array}{c}0.8314 \\
(0.7231 \text { to } \\
0.9397)\end{array}$ \\
\hline
\end{tabular}




\section{Discussion}

545 The five approaches examined above fail to support the classical belief about glucose insulin

546 relationship. The insulin receptor knock-out experiments and insulin suppression or

547 enhancement experiments converge to show that alteration in insulin levels or insulin

548 sensitivity does not change the steady-state glucose levels. Evidence that it changes the shape

549 of the glucose curve after food intake or glucose loading is more convincing in spite of some

550 inconsistency across different experiments. Typically return to the steady-state is delayed by

551 impaired insulin signalling but the steady-state glucose level remains unchanged.

552 Convergence of experiments using other means of causing specific alterations in insulin

553 action strengthens the inference.

554 A number of mathematical models attempt to capture the dynamics of glucose homeostasis.

555 A good model should be able to explain all the empirical results summed up here namely the

556 inability of insulin receptor knockouts, insulin suppression and insulin enhancement

557 experiments to alter steady state glucose levels; the difference in the regression correlation

558 parameters between insulin and glucose in the steady versus perturbed state; the extremely

559 weak correlation between fasting glucose and fasting insulin, but very strong correlation

560 between HOMA-IR and HOMA- $\beta$; the hyperinsulinemic-normoglycemic prediabetic state

561 and the phenomenon of impaired glucose tolerance but normal fasting glucose. Reviewing

562 models of glucose homeostasis is beyond the scope of this paper, but we outline here what a

563 good model of glucose homeostasis needs to explain. In our observation, all existing models

564 explain only some of the empirical findings. We suggest here that this inability is because of

565 a questionable common baseline assumption of all models that insulin signalling determines

566 the glucose level in the fasting as well as post feeding conditions. It should be possible to 
567 construct such a model, if we realize that insulin affects glucose only in the post feeding but 568 not in fasting conditions.

570 It is difficult to defend the classical assumptions about glucose-insulin relationship against

571 the multiple convergent lines of evidence. Although results of these experiments have been

572 there in the published literature for about two decades, these results were mostly explained

573 away giving different excuses for different sets of experiments. The possible lines of defence

574 would include difference between homeostatic mechanisms in rodents and humans or the

575 possibility of non-linear nature of glucose-insulin relationship. The evidence reviewed here

576 comes from rodents as well as humans and the glucose insulin scatters do not show any clear

577 indication of non-linearity. Further it would be prudent to avoid making inferences based on

578 dietary or other complex interventions since they can have multiple mechanisms of action.

579 Specific genetic or molecular interventions are more revealing with respect to the underlying

580 mechanisms since we can be more confident about their specificity of action. Therefore our

581 inference that insulin action does not influence fasting glucose levels is the most

582 straightforward and parsimonious inference. Any other explanations will have to be

583 supported by giving evidence for the assumptions made in those explanations.

The failure of experimental alteration in insulin signalling to alter steady-state glucose raises

586 two distinct possibilities about fasting hyperglycaemia in T2D. One is that fasting

hyperglycaemia in $\mathrm{T} 2 \mathrm{D}$ is a result of processes independent of insulin signalling such as 
reach a steady state, therefore fasting hyperglycaemia in T2D is a non-steady-state phenomenon in type 2 diabetes. The considerably weaker but still significant correlation between glucose and insulin in fasting as compared to post glucose load data suggests that both the factors are likely to be operational differentially in different individuals.

In either case certain fundamental concepts in our understanding of T2D need to be revised. First of all, the definition and measurement of insulin resistance using steady-state glucose and insulin levels needs to be questioned. Most commonly used indices of insulin resistance are based on the assumption that insulin signalling decides the fasting steady-state glucose levels, although non-equilibrium methods of assessing insulin resistance have been described (112). In the classical view other mechanisms of glucose regulation are assumed to be absent or non-significant. If increased sympathetic signalling increases liver glucose production, HOMA-IR will still account it as "insulin resistance". The same is true about insulin resistance measured by hyperinsulinemic euglycemic clamp. The way insulin resistance is measured at the clinical level eliminates the chance of separately accounting for other mechanisms of glucose regulation. Even when experiments show that certain agents affect glucose dynamics independent of insulin action, they are typically labelled as "insulin sensitizing" agents (113). As a result, the belief that insulin is the only mechanism of glucose regulation relevant to $\mathrm{T} 2 \mathrm{D}$ is artificially strengthened. There is a subtle circularity in the working definition of insulin resistance. Insulin resistance is blamed for the failure of normal or elevated levels of insulin to regulate glucose. In order to test this hypothesis, we should have an independent definition and measure of insulin resistance. Only then we can test whether and to what extent insulin resistance can alter glucose dynamics. However, clinically insulin resistance is measured by the inability of insulin to regulate glucose. Such a measure cannot be used to test the hypothesis that insulin resistance leads to the failure of 
617 insulin to regulate glucose. The unfalsifiability of the insulin resistance hypothesis arising out

618 of this circularity has halted any attempts towards realistic assessments of the true causes of

619 fasting hyperglycaemia in type 2 diabetes. In the molecular approach to induce insulin

620 resistance, we have an independent definition and causality for insulin resistance and

621 therefore such experiments are free from circularity of definition. The results of such

622 experiments reviewed here are therefore more revealing and reliable. Since all of them

623 converge to show that altering insulin signalling does not alter steady-state glucose levels, the

624 insulin resistance and inadequate compensation hypothesis for steady-state hyperglycaemia

625 stands clearly rejected.

626 The question can be turned upside down to examine whether steady-state glucose level

627 determines steady-state insulin. If glucose is infused with a constant rate over a long time,

628 insulin levels will come back to the baseline levels if glucose is not a determinant of fasting

629 insulin. If it is, then insulin levels will stabilize at a new heightened steady-state level. Jetton

630 et al. (2008) infused intra venous glucose (20\% glucose w/v) continuously for 4 days in rats.

631 Both glucose and insulin levels increased significantly after the infusion. However, later both

632 glucose and insulin levels came back to normal even as the infusion continued. Increase in

633 the concentration of the infused glucose (up to 35\%) also yielded similar results (115). Thus,

634 immediately on perturbation, glucose affected insulin levels, however after allowing

635 sufficient time to regain steady state, the continued infusion of glucose had no significant

636 effect on insulin levels. This demonstrates that even glucose does not hold a causal

637 relationship with insulin in a steady-state whereas glucose level perturbation is certainly

638 known to stimulate insulin response.

640 The interpretation of this phenomenon needs to be done at a broader philosophical level. We

641 point out here with specific reference to homeostatic systems that the nature of causality in a 
642 perturbed-state can be qualitatively different from causality in steady state. There is a simple

643 analogue to perturbed-state versus steady-state causality in one of the basic models of

644 mathematical biology. In the classical model of logistic growth the intrinsic growth rate $r$

645 decides the rate at which a population can change when away from the carrying capacity $K$

646 (116). However, the carrying capacity itself may be independent of the growth rate. A non-

647 zero positive $r$ is required to reach the steady-state at $K$ but $r$ does not determine the steady-

648 state level. It is a function of $K$ alone. Reducing $r$ leads to delay in achieving a steady state

649 but the steady state remains at the same position. The evidence reviewed here indicates that

650 insulin action is analogous to $r$ of logistic model. It is required to reach a steady-state but it

651 does not determine the location of the steady state.

653 The inability to distinguish between steady-state causality and perturbed-state causality may

654 have substantially misled biomedical research at times, T2D certainly being an important

example. This poses an important philosophical as well as methodological problem in

experimental physiology. Many systems in physiology have homeostatic steady states and we

use experimental approaches to reveal them. However, most experiments are perturbation

experiments and we may be making the mistake of applying the demonstrated perturbed-state

causality to understand steady-state systems. The apparent paradox can be resolved only by

carefully designing and interpreting experiments. If a perturbation is momentary or transient,

661 the results obtained would certainly reflect perturbed-state causality, but may not reflect

steady-state causality. On the other hand, sustained perturbations held constant for 
666 other hand, sustained alteration in the causal factor results into an altered steady state, it

667 indicates steady-state causality.

668 Viewed from a slightly different and more generalized angle that goes beyond homeostatic

669 systems, we can differentiate between two types of causalities. In driver causality the causal

670 factor is necessary to reach a destination but does not decide the destination. In navigator

671 causality the causal factor is crucial in determining the destination, but may not be sufficient

672 to take the system there. The evidence reviewed above indicates that insulin is a driver but

673 not a navigator of glucose homeostasis. A non-zero level of insulin is required for reaching a

674 homeostatic steady state. In type 1 diabetes, the almost complete absence of insulin prevents

675 glucose homeostasis. In type 2 diabetes there are non-zero insulin levels and therefore, a

676 steady-state is possible, but insulin itself plays little role in deciding the steady-state glucose

677 level. It is more likely that neuronal and other hormonal-metabolic factors affect the steady-

678 state glucose in T2D.

679 Certain kinds of experimental interventions are unable to distinguish between driver versus

navigator causality. Knocking out a driver or a navigator will disable the journey to the

destination. Therefore, complete knockout of a cause may not distinguish between driver and navigator causality. On the other hand, experiments quantitatively altering the level of the causal factor while keeping it non-zero and observing the effect for sufficiently long duration, can help us differentiate between drivers and navigators. A sub-normal driver will delay the time to destination but will not change the destination. On the other hand, changing the navigator may or may not alter the time, but will alter the position of the destination. The history of insulin research is that early experiments such as total pancreatectomy demonstrated the necessary role of insulin in glucose homeostasis but the distinction between driver or navigator causality was not even conceptually perceived. So, it was assumed that insulin does both the roles. Although the absence of correlation between fasting glucose and 
691 insulin but good correlation after perturbation was noted as early as 1969 (117) but in the

692 absence of conceptual differentiation between steady state and perturbed state causality, a

693 clear interpretation did not emerge. Now in the presence of multiple experiments showing the

694 precise role of insulin, we need to revive our concepts of causality. At a broader scale the

695 insulin example warrants care in making inferences in experimental physiology, in the

696 absence of which our understanding of the physiology of homeostatic systems can be

697 seriously flawed.

\section{Acknowledgements}

700 We would like to thank Prof. Raj Bhopal, University of Edinburgh for providing clinical data

701 from the Newcastle Heart Project. We would also like to thank Prof. Chittaranjan Yajnik,

702 KEM Hospital, Pune for providing the clinical data from the CRISIS study. We are

703 immensely grateful for the critical and insightful comments they provided on the earlier

704 version of the manuscript. We would also like to thank Geetanjali Nerurkar for her help

705 during the animal experiments.

706

707

\section{Conflict of interest statement}

708 There was no specific funding for this study. The authors have no conflicts of interest to 709 declare. 


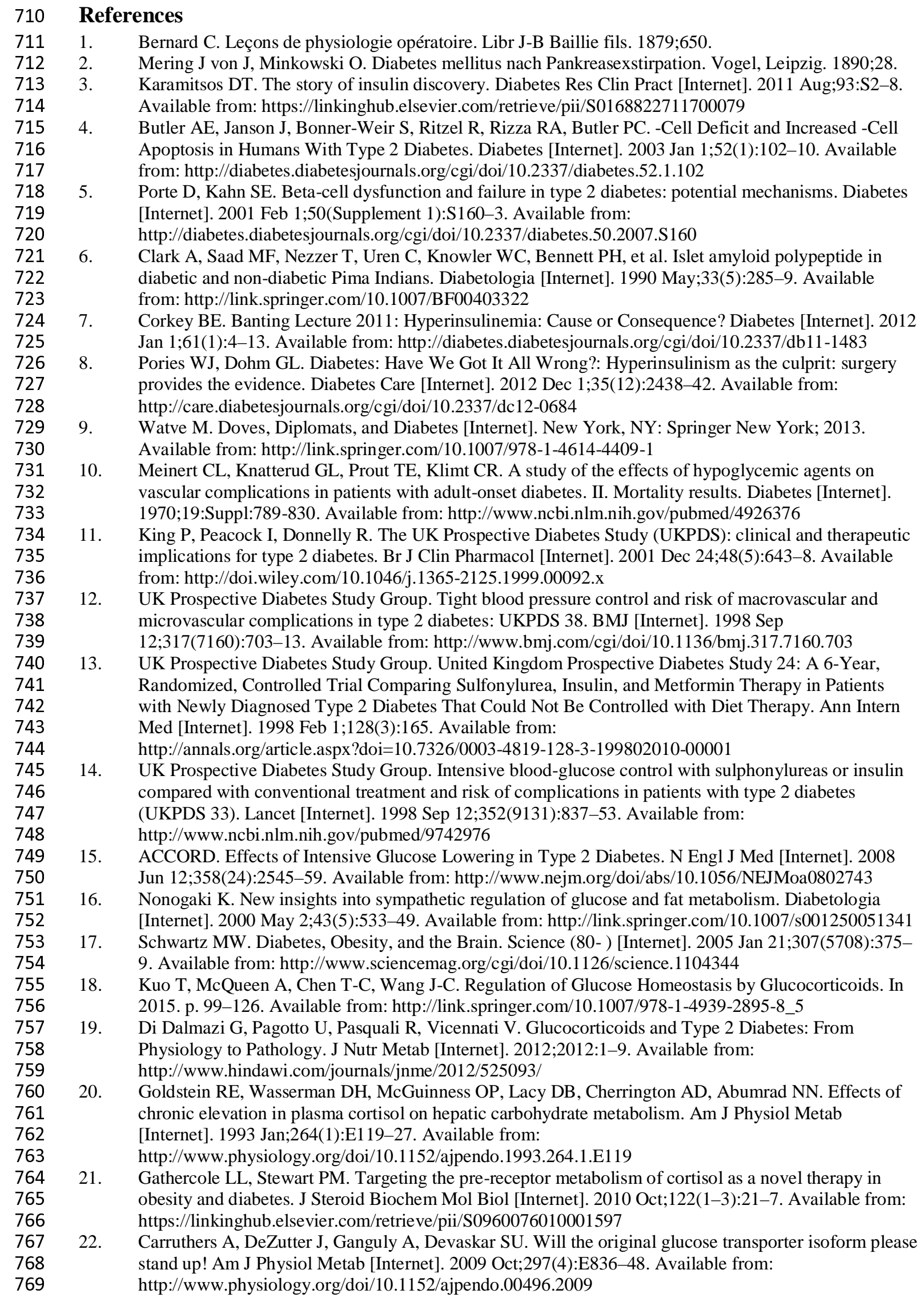

5. Porte D, Kahn SE. Beta-cell dysfunction and failure in type 2 diabetes: potential mechanisms. Diabetes [Internet]. 2001 Feb 1;50(Supplement 1):S160-3. Available from: http://diabetes.diabetesjournals.org/cgi/doi/10.2337/diabetes.50.2007.S160

6. Clark A, Saad MF, Nezzer T, Uren C, Knowler WC, Bennett PH, et al. Islet amyloid polypeptide in diabetic and non-diabetic Pima Indians. Diabetologia [Internet]. 1990 May;33(5):285-9. Available from: http://link.springer.com/10.1007/BF00403322

7. Corkey BE. Banting Lecture 2011: Hyperinsulinemia: Cause or Consequence? Diabetes [Internet]. 2012 Jan 1;61(1):4-13. Available from: http://diabetes.diabetesjournals.org/cgi/doi/10.2337/db11-1483

8. Pories WJ, Dohm GL. Diabetes: Have We Got It All Wrong?: Hyperinsulinism as the culprit: surgery provides the evidence. Diabetes Care [Internet]. 2012 Dec 1;35(12):2438-42. Available from: http://care.diabetesjournals.org/cgi/doi/10.2337/dc12-0684

9. Watve M. Doves, Diplomats, and Diabetes [Internet]. New York, NY: Springer New York; 2013. Available from: http://link.springer.com/10.1007/978-1-4614-4409-1

10. Meinert CL, Knatterud GL, Prout TE, Klimt CR. A study of the effects of hypoglycemic agents on vascular complications in patients with adult-onset diabetes. II. Mortality results. Diabetes [Internet]. 1970;19:Suppl:789-830. Available from: http://www.ncbi.nlm.nih.gov/pubmed/4926376

11. King P, Peacock I, Donnelly R. The UK Prospective Diabetes Study (UKPDS): clinical and therapeutic implications for type 2 diabetes. Br J Clin Pharmacol [Internet]. 2001 Dec 24;48(5):643-8. Available from: http://doi.wiley.com/10.1046/j.1365-2125.1999.00092.x

12. UK Prospective Diabetes Study Group. Tight blood pressure control and risk of macrovascular and microvascular complications in type 2 diabetes: UKPDS 38. BMJ [Internet]. 1998 Sep 12;317(7160):703-13. Available from: http://www.bmj.com/cgi/doi/10.1136/bmj.317.7160.703

13. UK Prospective Diabetes Study Group. United Kingdom Prospective Diabetes Study 24: A 6-Year, Randomized, Controlled Trial Comparing Sulfonylurea, Insulin, and Metformin Therapy in Patients with Newly Diagnosed Type 2 Diabetes That Could Not Be Controlled with Diet Therapy. Ann Intern Med [Internet]. 1998 Feb 1;128(3):165. Available from: http://annals.org/article.aspx?doi=10.7326/0003-4819-128-3-199802010-00001

14. UK Prospective Diabetes Study Group. Intensive blood-glucose control with sulphonylureas or insulin compared with conventional treatment and risk of complications in patients with type 2 diabetes (UKPDS 33). Lancet [Internet]. 1998 Sep 12;352(9131):837-53. Available from: http://www.ncbi.nlm.nih.gov/pubmed/9742976

15. ACCORD. Effects of Intensive Glucose Lowering in Type 2 Diabetes. N Engl J Med [Internet]. 2008 Jun 12;358(24):2545-59. Available from: http://www.nejm.org/doi/abs/10.1056/NEJMoa0802743

16. Nonogaki K. New insights into sympathetic regulation of glucose and fat metabolism. Diabetologia [Internet]. 2000 May 2;43(5):533-49. Available from: http://link.springer.com/10.1007/s001250051341

17. Schwartz MW. Diabetes, Obesity, and the Brain. Science (80- ) [Internet]. 2005 Jan 21;307(5708):3759. Available from: http://www.sciencemag.org/cgi/doi/10.1126/science.1104344

18. Kuo T, McQueen A, Chen T-C, Wang J-C. Regulation of Glucose Homeostasis by Glucocorticoids. In 2015. p. 99-126. Available from: http://link.springer.com/10.1007/978-1-4939-2895-8_5

19. Di Dalmazi G, Pagotto U, Pasquali R, Vicennati V. Glucocorticoids and Type 2 Diabetes: From Physiology to Pathology. J Nutr Metab [Internet]. 2012;2012:1-9. Available from: http://www.hindawi.com/journals/jnme/2012/525093/

20. Goldstein RE, Wasserman DH, McGuinness OP, Lacy DB, Cherrington AD, Abumrad NN. Effects of chronic elevation in plasma cortisol on hepatic carbohydrate metabolism. Am J Physiol Metab [Internet]. 1993 Jan;264(1):E119-27. Available from: http://www.physiology.org/doi/10.1152/ajpendo.1993.264.1.E119

21. Gathercole LL, Stewart PM. Targeting the pre-receptor metabolism of cortisol as a novel therapy in obesity and diabetes. J Steroid Biochem Mol Biol [Internet]. 2010 Oct;122(1-3):21-7. Available from: https://linkinghub.elsevier.com/retrieve/pii/S0960076010001597

22. Carruthers A, DeZutter J, Ganguly A, Devaskar SU. Will the original glucose transporter isoform please stand up! Am J Physiol Metab [Internet]. 2009 Oct;297(4):E836-48. Available from: http://www.physiology.org/doi/10.1152/ajpendo.00496.2009 
23. Clemmons DR. Role of Insulin-Like Growth Factor Iin Maintaining Normal Glucose Homeostasis. Horm Res Paediatr [Internet]. 2004;62(1):77-82. Available from: https://www.karger.com/Article/FullText/80763

24. Jansen C, Lundquist I, Salehi A, Axelson J, Ohlsson B. Does Epidermal Growth Factor Participate in the Regulation of Glucose, Insulin and Glucagon Levels? Eur Surg Res [Internet]. 2006;38(4):377-84. Available from: https://www.karger.com/Article/FullText/94533

25. Messmer-Blust AF, Philbrick MJ, Guo S, Wu J, He P, Guo S, et al. RTEF-1 Attenuates Blood Glucose Levels by Regulating Insulin-Like Growth Factor Binding Protein-1 in the Endothelium. Circ Res [Internet]. 2012 Sep 28;111(8):991-1001. Available from: https://www.ahajournals.org/doi/10.1161/CIRCRESAHA.112.268110

26. Suh JM, Jonker JW, Ahmadian M, Goetz R, Lackey D, Osborn O, et al. Endocrinization of FGF1 produces a neomorphic and potent insulin sensitizer. Nature [Internet]. 2014 Sep 16;513(7518):436-9. Available from: http://www.nature.com/articles/nature 13540

27. Kulkarni S, Sharda S, Watve M. Bi-stability in type 2 diabetes mellitus multi-organ signalling network. Cras-Méneur C, editor. PLoS One [Internet]. 2017 Aug 2;12(8):e0181536. Available from: https://dx.plos.org/10.1371/journal.pone.0181536

28. Turner RC, Holman RR, Matthews D, Hockaday TDR, Peto J. Insulin deficiency and insulin resistance interaction in diabetes: Estimation of their relative contribution by feedback analysis from basal plasma insulin and glucose concentrations. Metabolism [Internet]. 1979 Nov;28(11):1086-96. Available from: http://linkinghub.elsevier.com/retrieve/pii/002604957990146X

29. Matthews DR, Hosker JP, Rudenski AS, Naylor BA, Treacher DF, Turner RC. Homeostasis model assessment: insulin resistance and $\square$ ?-cell function from fasting plasma glucose and insulin concentrations in man. Diabetologia [Internet]. 1985 Jul;28(7):412-9. Available from: http://link.springer.com/10.1007/BF00280883

30. Chawla S, Pund A, B. V, Kulkarni S, Diwekar-Joshi M, Watve M. Inferring causal pathways among three or more variables from steady-state correlations in a homeostatic system. Ruscica M, editor. PLoS One [Internet]. 2018 Oct 11;13(10):e0204755. Available from: http://dx.plos.org/10.1371/journal.pone.0204755

31. AKHTAR A. The Flaws and Human Harms of Animal Experimentation. Cambridge Q Healthc Ethics [Internet]. 2015 Oct 14;24(04):407-19. Available from: http://www.journals.cambridge.org/abstract_S0963180115000079

32. Ali Z, Chandrasekera PC, Pippin JJ. Animal research for type 2 diabetes mellitus, its limited translation for clinical benefit, and the way forward. Altern Lab Anim [Internet]. 2018 Mar;46(1):13-22. Available from: http://www.ncbi.nlm.nih.gov/pubmed/29553794

33. Bracken MB. Why animal studies are often poor predictors of human reactions to exposure. J R Soc Med [Internet]. 2009 Mar 18;102(3):120-2. Available from: http://journals.sagepub.com/doi/10.1258/jrsm.2008.08k033

34. Bevan P. Insulin signalling. J Cell Sci [Internet]. 2001 Apr;114(Pt 8):1429-30. Available from: http://www.ncbi.nlm.nih.gov/pubmed/11282018

35. Bock G, Chittilapilly E, Basu R, Toffolo G, Cobelli C, Chandramouli V, et al. Contribution of Hepatic and Extrahepatic Insulin Resistance to the Pathogenesis of Impaired Fasting Glucose: Role of Increased Rates of Gluconeogenesis. Diabetes [Internet]. 2007 Jun 1;56(6):1703-11. Available from: http://diabetes.diabetesjournals.org/cgi/doi/10.2337/db06-1776

36. Lauro D, Kido Y, Castle a L, Zarnowski MJ, Hayashi H, Ebina Y, et al. Impaired glucose tolerance in mice with a targeted impairment of insulin action in muscle and adipose tissue. Nat Genet. 1998;20(3):294-8.

37. Guerra C, Navarro P, Valverde AM, Arribas M, Brüning J, Kozak LP, et al. Brown adipose tissue specific insulin receptor knockout shows diabetic phenotype without insulin resistance. J Clin Invest. 2001;108(8):1205-13.

38. Wojtaszewski JFP, Higaki Y, Hirshman MF, Michael MD, Dufresne SD, Kahn CR, et al. Exercise modulates postreceptor insulin signaling and glucose transport in muscle-specific insulin receptor knockout mice. J Clin Invest. 1999;

39. Mauvais-Jarvis F, Virkamaki A, Michael MD, Winnay JN, Zisman A, Kulkarni RN, et al. A model to explore the interaction between muscle insulin resistance and beta-cell dysfunction in the development of type 2 diabetes. Diabetes. 2000;

40. Blüher M, Michael MD, Peroni OD, Ueki K, Carter N, Kahn BB, et al. Adipose tissue selective insulin receptor knockout protects against obesity and obesity-related glucose intolerance. Dev Cell. 2002;

41. Otani K. Reduced -cell mass and altered glucose sensing impair insulin-secretory function in IRKO mice. AJP Endocrinol Metab. 2003;

42. Cohen SE, Tseng YH, Michael MD, Kahn CR. Effects of insulin-sensitising agents in mice with hepatic 
890

891

63. Lamberts SWJ, van der Lely A-J, de Herder WW, Hofland LJ. Octreotide. Wood AJJ, editor. N Engl J Med [Internet]. 1996 Jan 25;334(4):246-54. Available from: http://www.nejm.org/doi/10.1056/NEJM199601253340408

64. Farris W, Mansourian S, Chang Y, Lindsley L, Eckman EA, Frosch MP, et al. Insulin-degrading enzyme regulates the levels of insulin, amyloid beta-protein, and the beta-amyloid precursor protein intracellular domain in vivo. Proc Natl Acad Sci U S A [Internet]. 2003;100(7):4162-7. Available from: http://www.ncbi.nlm.nih.gov/pubmed/12634421\%5Cnhttp://www.ncbi.nlm.nih.gov/pubmed/12634421

65. Durham TB, Toth JL, Klimkowski VJ, Cao JXC, Siesky AM, Alexander-Chacko J, et al. Dual exositebinding inhibitors of insulin-degrading enzyme challenge its role as the primary mediator of insulin clearance in vivo. J Biol Chem. 2015;290(33):20044-59.

66. Deprez-Poulain R, Hennuyer N, Bosc D, Liang WG, Enée E, Marechal X, et al. Catalytic site inhibition of insulin-degrading enzyme by a small molecule induces glucose intolerance in mice. Nat Commun. $2015 ; 6$.

67. Abdul-Hay SO, Kang D, McBride M, Li L, Zhao J, Leissring MA. Deletion of insulin-degrading enzyme elicits antipodal, age-dependent effects on glucose and insulin tolerance. PLoS One [Internet]. 2011;6(6):e20818. Available from: http://www.ncbi.nlm.nih.gov/pubmed/21695259

68. Villa-Pérez P, Merino B, Fernández-Díaz CM, Cidad P, Lobatón CD, Moreno A, et al. Liver-specific ablation of insulin-degrading enzyme causes hepatic insulin resistance and glucose intolerance, without affecting insulin clearance in mice. Metabolism [Internet]. 2018;88:1-11. Available from: https://www.sciencedirect.com/science/article/pii/S0026049518301690

69. Wigand JP, Blackard WG. Downregulation of insulin receptors in obese man. Diabetes. 1979;28(4):287-91.

70. Leahy JL, Bumbalo LM, Chen C. Diazoxide causes recovery of beta-cell glucose responsiveness in $90 \%$ pancreatectomized diabetic rats. Diabetes [Internet]. 1994 Feb;43(2):173-9. Available from: http://doi.wiley.com/10.1046/j.1464-5491.1999.00150.x

71. Matsuda M, Kawasaki F, Mikami Y, Takeuchi Y, Saito M, Eto M, et al. Rescue of beta-cell exhaustion by diazoxide after the development of diabetes mellitus in rats with streptozotocin-induced diabetes. Eur J Pharmacol. 2002;453(1):141-8.

72. Schreuder T, Karreman M, Rennings A, Ruinemans-Koerts J, Jansen M, de Boer H. Diazoxidemediated insulin suppression in obese men: a dose-response study. Diabetes Obes Metab [Internet]. 2005 May;7(3):239-45. Available from: http://www.ncbi.nlm.nih.gov/pubmed/15811140

73. Due A, Flint A, Eriksen G, Møller B, Raben A, Hansen JB, et al. No effect of inhibition of insulin secretion by diazoxide on weight loss in hyperinsulinaemic obese subjects during an 8-week weight-loss diet. Diabetes, Obes Metab. 2007;9(4):566-74.

74. van Boekel G, Loves S, van Sorge A, Ruinemans-Koerts J, Rijnders T, de Boer H. Weight loss in obese men by caloric restriction and high-dose diazoxide-mediated insulin suppression. Diabetes, Obes Metab. 2008;10(12):1195-203.

75. Ramanathan RP, Arbeláez AM, Cryer PE. Partial inhibition of insulin secretion results in glucose intolerance but not hyperglucagonemia. Diabetes. 2011;60(4):1324-8.

76. Brauner R, Serreau R, Souberbielle JC, Pouillot M, Grouazel S, Recasens C, et al. Diazoxide in children with obesity after hypothalamic-pituitary lesions: A randomized, placebo-controlled trial. J Clin Endocrinol Metab. 2016;101(12):4825-33.

77. Breckenridge SM, Cooperberg BA, Arbelaez AM, Patterson BW, Cryer PE. Glucagon, in concert with insulin, supports the postabsorptive plasma glucose concentration in humans. Diabetes. 2007;56(10):2442-8.

78. Candrina R, Gussago A, Giustina G. Effect of a new long-acting somatostatin analogue (SMS 201-995) on glycemic and hormonal response to a mixed meal in acromegalic patients. J Endocrinol Invest. 1988;11(1):21-6.

79. Davies RR, Miller M, Turner SJ, Watson M, McGill A, Orskov H, et al. Effects of somatostatin analogue SMS 201-995 in non-insulin-dependent diabetes. Clin Endocrinol (Oxf). 1986;25(6):739-47.

80. Giustina A, Girelli A, Buffoli MG, Cimino A, Legati F, Valentini U, et al. Low-dose octreotide is able to cause a maximal inhibition of the glycemic responses to a mixed meal in obese type 2 diabetic patients treated with insulin. Diabetes Res Clin Pract. 1991;14(1):47-54.

81. Johnston DG, Davies RR, Alberti KGMM, Miller M, Turner SJ, Watson M, et al. Effects of SMS 201995 on intermediary metabolism and endocrine status in normal and diabetic humans. Am J Med. 1986;81(6 SUPPL. 2):88-93.

82. Madsen M, Poulsen PL, Ørskov H, Møller N, Jørgensen JOL. Cotreatment with pegvisomant and a Somatostatin Analog (SA) in SA-responsive acromegalic patients. J Clin Endocrinol Metab. 2011;96(8):2405-13.

83. Parkinson C, Drake WM, Roberts ME, Meeran K, Besser GM, Trainer PJ. A comparison of the effects 
of pegvisomant and octreotide on glucose, insulin, gastrin, cholecystokinin, and pancreatic polypeptide responses to oral glucose and a standard mixed meal. J Clin Endocrinol Metab. 2002;87(4):1797-804.

84. Ronchi C, Epaminonda P, Cappiello V, Beck-Peccoz P, Arosio M. Effects of two different somatostatin analogs on glucose tolerance in acromegaly. J Endocrinol Invest [Internet]. 2002 Jun 22;25(6):502-7. Available from: http://link.springer.com/10.1007/BF03345491

85. Williams G, Fuessl HS, Burrin JM, Chilvers E, Bloom SR. Postprandial glycaemic effects of a longacting somatostatin analogue (octreotide) in non-insulin dependent diabetes mellitus. Horm Metab Res. 1988;20(3):168-70.

86. Williams G, Fuessl H, Kraenzlin M, Bloom SR. Postprandial effects of SMS 201-995 on gut hormones and glucose tolerance. Scand J Gastroenterol. 1986;21(S119):73-83.

87. Schteingart DE, McKenzie AK, Victoria RS, Tsao HS. Suppression of insulin secretion by protein deprivation in obesity. Metabolism. 1979;28(9):943-9.

88. Hwang D, Seo S, Kim Y, Kim C, Shim S, Jee S, et al. Significant change in insulin production, glucose tolerance and ER stress signaling in transgenic mice coexpressing insulin-siRNA and human IDE. Int J Mol Med [Internet]. 2007 Jan 1; Available from: http://www.spandidos-

publications.com/10.3892/ijmm.19.1.65

89. Duvillie B, Cordonnier N, Deltour L, Dandoy-Dron F, Itier J-M, Monthioux E, et al. Phenotypic alterations in insulin-deficient mutant mice. Proc Natl Acad Sci [Internet]. 1997 May 13;94(10):5137_ 40. Available from: http://www.pnas.org/cgi/doi/10.1073/pnas.94.10.5137

90. Mehran AE, Templeman NM, Brigidi GS, Lim GE, Chu K, Hu X, et al. Hyperinsulinemia Drives DietInduced Obesity Independently of Brain Insulin Production. Cell Metab [Internet]. 2012;16(6):723-37. Available from: http://dx.doi.org/10.1016/j.cmet.2012.10.019

91. Page MM, Skovsø S, Cen H, Chiu AP, Dionne DA, Hutchinson DF, et al. Reducing insulin via conditional partial gene ablation in adults reverses diet-induced weight gain. 2019;

92. Templeman NM, Clee SM, Johnson JD. Suppression of hyperinsulinaemia in growing female mice provides long-term protection against obesity. 2015;2392-402.

93. Dionne DA, Skovsø S, Templeman NM, Clee SM, Johnson JD. Caloric restriction paradoxically increases adiposity in Mice With Genetically Reduced Insulin. 2016;157(July):2724-34.

94. Templeman NM, Flibotte S, Chik JHL, Foster LJ, Nislow C, Johnson JD, et al. Reduced Circulating Insulin Enhances Insulin Sensitivity in Old Mice and Extends Lifespan. CellReports [Internet]. 2017;20(2):451-63. Available from: http://dx.doi.org/10.1016/j.celrep.2017.06.048

95. Halter JB, Ward WK, Porte D, Best JD, Pfeifer MA. Glucose regulation in non-insulin-dependent diabetes mellitus. Interaction between pancreatic islets and the liver. Am J Med [Internet]. 1985 Aug 23;79(2B):6-12. Available from: http://www.ncbi.nlm.nih.gov/pubmed/2863979

96. Lerner RL, Porte D. Acute and steady-state insulin responses to glucose in nonobese diabetic subjects. J Clin Invest [Internet]. 1972 Jul 1;51(7):1624-31. Available from: http://www.jci.org/articles/view/106963

97. Palumbo P, Ditlevsen S, Bertuzzi A, De Gaetano A. Mathematical modeling of the glucose-insulin system: A review. Math Biosci [Internet]. 2013 Aug;244(2):69-81. Available from: https://linkinghub.elsevier.com/retrieve/pii/S0025556413001302

98. Bergman RN. Toward Physiological Understanding of Glucose Tolerance: Minimal-Model Approach. Diabetes [Internet]. 1989 Dec 1;38(12):1512-27. Available from: http://diabetes.diabetesjournals.org/cgi/doi/10.2337/diab.38.12.1512

99. Bergman RN. Minimal Model: Perspective from 2005. Horm Res Paediatr [Internet]. 2005;64(3):8-15. Available from: https://www.karger.com/Article/FullText/89312

100. Makroglou A, Li J, Kuang Y. Mathematical models and software tools for the glucose-insulin regulatory system and diabetes: an overview. Appl Numer Math [Internet]. 2006 Mar;56(3-4):559-73. Available from: http://linkinghub.elsevier.com/retrieve/pii/S0168927405000929

101. Coggan AR. Plasma Glucose Metabolism During Exercise in Humans. Sport Med [Internet]. 1991 Feb;11(2):102-24. Available from: http://link.springer.com/10.2165/00007256-199111020-00003

102. Roy A, Parker RS. DYNAMIC MODELING OF EXERCISE EFFECTS ON PLASMA GLUCOSE AND INSULIN LEVELS. IFAC Proc Vol [Internet]. 2006;39(2):509-14. Available from: https://linkinghub.elsevier.com/retrieve/pii/S1474667016353757

103. Garvey WT, Olefsky JM, Marshall S. Insulin Induces Progressive Insulin Resistance in Cultured Rat Adipocytes: Sequential Effects at Receptor and Multiple Postreceptor Sites. Diabetes [Internet]. 1986 Mar 1;35(3):258-67. Available from: http://diabetes.diabetesjournals.org/cgi/doi/10.2337/diab.35.3.258

104. Shanik MH, Xu Y, Skrha J, Dankner R, Zick Y, Roth J. Insulin Resistance and Hyperinsulinemia: Is hyperinsulinemia the cart or the horse? Diabetes Care [Internet]. 2008 Feb 1;31(Supplement 2):S262-8. Available from: http://care.diabetesjournals.org/cgi/doi/10.2337/dc08-s264

105. Weyer C, Hanson RL, Tataranni PA, Bogardus C, Pratley RE. A high fasting plasma insulin 
1010

1011

1012

1013

1014

1015

1016

1017

1018

1019

1020

1021

1022

1023

1024

1025

1026

1027

1028

1029

1030

1031

1032

1033

1034

1035

1036

1037

1038

1039

1040

1041

1042

1043

1044

1045

1046

1047

1048

1049

1050

1051

1052

1053

concentration predicts type 2 diabetes independent of insulin resistance: evidence for a pathogenic role of relative hyperinsulinemia. Diabetes [Internet]. 2000 Dec 1;49(12):2094-101. Available from: http://diabetes.diabetesjournals.org/cgi/doi/10.2337/diabetes.49.12.2094

106. Yajnik CS, Joglekar C V., Lubree HG, Rege SS, Naik SS, Bhat DS, et al. Adiposity, inflammation and hyperglycaemia in rural and urban Indian men: Coronary Risk of Insulin Sensitivity in Indian Subjects (CRISIS) Study. Diabetologia [Internet]. 2007 Nov 29;51(1):39-46. Available from: http://link.springer.com/10.1007/s00125-007-0847-1

107. Bhopal R, Unwin N, White M, Yallop J, Walker L, Alberti KGMM, et al. Heterogeneity of coronary heart disease risk factors in Indian, Pakistani, Bangladeshi, and European origin populations: cross sectional study. BMJ [Internet]. 1999 Jul 24;319(7204):215-20. Available from: http://www.bmj.com/cgi/doi/10.1136/bmj.319.7204.215

108. Bhopal RS. A four-stage model explaining the higher risk of Type 2 diabetes mellitus in South Asians compared with European populations. Diabet Med [Internet]. 2013 Jan;30(1):35-42. Available from: http://doi.wiley.com/10.1111/dme.12016

109. Gujral UP, Pradeepa R, Weber MB, Narayan KMV, Mohan V. Type 2 diabetes in South Asians: similarities and differences with white Caucasian and other populations. Ann N Y Acad Sci [Internet]. 2013 Apr;1281(1):51-63. Available from: http://doi.wiley.com/10.1111/j.1749-6632.2012.06838.x

110. Thorp AA, Schlaich MP. Relevance of Sympathetic Nervous System Activation in Obesity and Metabolic Syndrome. J Diabetes Res [Internet]. 2015;2015:1-11. Available from: http://www.hindawi.com/journals/jdr/2015/341583/

111. Bruce DG, Chisholm DJ, Storlien LH, Kraegen EW, Smythe GA. The effects of sympathetic nervous system activation and psychological stress on glucose metabolism and blood pressure in subjects with Type 2 (non-insulin-dependent) diabetes mellitus. Diabetologia [Internet]. 1992 Sep;35(9):835-43. Available from: http://link.springer.com/10.1007/BF00399929

112. Patarrão RS, Lautt WW, Afonso RA, Ribeiro RT, Fernandes AB, Boavida JM, et al. Postprandial but not fasting insulin resistance is an early identifier of dysmetabolism in overweight subjects. Can J Physiol Pharmacol [Internet]. 2012 Jul;90(7):923-31. Available from: http://www.nrcresearchpress.com/doi/10.1139/y2012-086

113. Hossain Z, Valicherla GR, Gupta AP, Syed AA, Riyazuddin M, Chandra S, et al. Discovery of pancreastatin inhibitor PSTi8 for the treatment of insulin resistance and diabetes: Studies in rodent models of diabetes mellitus. Sci Rep [Internet]. 2018;8(1):1-13. Available from: http://dx.doi.org/10.1038/s41598-018-27018-8

114. Jetton TL, Everill B, Lausier J, Roskens V, Habibovic A, LaRock K, et al. Enhanced $\beta$-cell mass without increased proliferation following chronic mild glucose infusion. Am J Physiol Metab [Internet]. 2008 Apr;294(4):E679-87. Available from: http://www.physiology.org/doi/10.1152/ajpendo.00569.2007

115. Steil GM, Trivedi N, Jonas J-C, Hasenkamp WM, Sharma A, Bonner-Weir S, et al. Adaptation of $\beta$-cell mass to substrate oversupply: enhanced function with normal gene expression. Am J Physiol Metab [Internet]. 2001 May;280(5):E788-96. Available from: http://www.physiology.org/doi/10.1152/ajpendo.2001.280.5.E788

116. Gotelli NJ. A Primer of Ecology. 2008. Sinauer.

117. Goodner CJ, Conway MJ, Werrbach JH. Control of insulin secretion during fasting hyperglycemia in adult diabetics and in nondiabetic subjects during infusion of glucose. J Clin Invest 1969; 48: 1178-87. 
1054

1055

1056

1057

1058

1059

1060

1061

1062

1063

1064

1065

1066

1067

1068

1069

1070

1071

1072

1073

1074

1075

1076

1077

1078

1079

1080

1081

1082

1083

1084

\section{Supplementary information 1: Methods used for the meta-analyses}

\section{Four meta-analyses were performed in this study:}

1. Insulin receptor knockout

2. Insulin degrading enzyme

3. Insulin suppression by diazoxide

4. Insulin suppression by octreotide

\section{Methods used for the four meta-analyses:}

Keywords: The keywords used in the meta analyses have been given in the table 1 of the main manuscript.

Data-bases: We have used the PubMed/MEDLINE database (and not the data bases which report clinical trials data) since the experiments we were searching for are predominantly experiments in basic research in life sciences as opposed to clinical studies. Majority of the studies which were searching for were rodent studies and not human studies.

Timeline for inclusion of papers in the search: The first search was performed in August 2017 and the papers until $31^{\text {st }}$ July 2017 were included in the primary search.

Inclusion and exclusion criteria: Given in the table 2 of the main paper

Details of the papers: Tables 1,2,3,4 below

Methods of data extraction: Data was extracted from the shortlisted papers using the software WebPlotDigitizer (Author: Ankit Rohatgi

Website: https://automeris.io/WebPlotDigitizer, Version: 4.1, January, 2018, E-Mail: ankitrohatgi@hotmail.com, Location: Austin, Texas, USA)

Principal summary measures: The data extracted from each shortlisted paper was the difference of means of blood/plasma glucose levels between the 'control' and the 'treated' along with the $95 \%$ confidence intervals.

Methods of handling data and combining results of studies: These differences in the means between the control and treated from all the respective shortlisted papers were compiled. These differences were compared across different timepoints using the nonparametric chi-square test. 
1086 Details of the papers shortlisted for the four meta-analyses:

1087 Table 1: Details of the 16 papers used in the Insulin Receptor Knock-Out (IRKO) meta-analysis. All of these studies were carried out on rodent 1088 models.

\begin{tabular}{|c|c|c|c|c|c|c|}
\hline $\begin{array}{l}\text { Sr. } \\
\text { No. }\end{array}$ & Reference & Type of IRKO & $\begin{array}{l}\text { Method used } \\
\text { to make the } \\
\text { knockout }\end{array}$ & $\begin{array}{l}\text { Fasting duration } \\
\text { before the GTT } \\
\text { (Glucose tolerance } \\
\text { test) }\end{array}$ & $\begin{array}{l}\text { Glucose } \\
\text { concentration/ mode } \\
\text { of glucose infusion } \\
\text { used in GTT } \\
\end{array}$ & Sample size \\
\hline 1 & $\begin{array}{l}\text { Sakaguchi et al } \\
2017 \text { (1) }\end{array}$ & $\begin{array}{l}\text { inducible-BATIRKO (brown } \\
\text { adipose tissue IRKO) }\end{array}$ & $\begin{array}{l}\text { Cre-loxP } \\
\text { system }\end{array}$ & 6 hours & $\begin{array}{l}2 \mathrm{~g} / \mathrm{kg} \text { dextrose given } \\
\text { orally }\end{array}$ & $\begin{array}{l}\text { Control } \mathrm{n}=13 \\
\text { IRKO, } \mathrm{n}=12\end{array}$ \\
\hline \multirow[t]{2}{*}{2} & \multirow[t]{2}{*}{$\begin{array}{l}\text { Softic et al } 2016 \\
\text { (2) }\end{array}$} & $\begin{array}{l}\text { FIRKO (Fat IRKO) (12 weeks } \\
\text { old male mice) }\end{array}$ & \multirow[t]{2}{*}{$\begin{array}{l}\text { Cre-loxP } \\
\text { system }\end{array}$} & \multirow[t]{2}{*}{ Overnight (ON) } & \multirow[t]{2}{*}{ Random fed } & $\begin{array}{l}\mathrm{n}=12 \text { to } 30 \text { for each } \\
\text { group }\end{array}$ \\
\hline & & $\begin{array}{l}\text { FIRKO (52 weeks old male } \\
\text { mice) }\end{array}$ & & & & $\begin{array}{l}\mathrm{n}=5 \text { to } 6 \text { for each } \\
\text { group }\end{array}$ \\
\hline 3 & Haas et al 2012 (3) & LIRKO (Liver IRKO) & $\begin{array}{l}\text { Cre-loxP } \\
\text { system }\end{array}$ & $\mathrm{ON}$ & $\begin{array}{l}1 \mathrm{~g} / \mathrm{kg} \text { dextrose } \\
\text { i.p.(intraperitoneal) }\end{array}$ & $\begin{array}{l}\mathrm{n}=3 \text { to } 5 \text { for each } \\
\text { group }\end{array}$ \\
\hline \multirow[t]{2}{*}{4} & \multirow[t]{2}{*}{$\begin{array}{l}\text { Kawamori et al } \\
2009 \text { (4) }\end{array}$} & $\begin{array}{l}\alpha \operatorname{IRKO}(\alpha \text {-cell IRKO) }(2,5,12- \\
\text { month-old mice })\end{array}$ & \multirow[t]{2}{*}{$\begin{array}{l}\text { Cre-loxP } \\
\text { system }\end{array}$} & 16 hours & Random fed & $\begin{array}{l}\mathrm{n}=6 \text { to } 8 \text { for each } \\
\text { group }\end{array}$ \\
\hline & & $\alpha \operatorname{IRKO}(2,5$-month-old mice) & & 16 hours & $1 \mathrm{~g} / \mathrm{kg}$ dextrose i.p. & $\begin{array}{l}\mathrm{n}=3 \text { to } 12 \text { for each } \\
\text { group }\end{array}$ \\
\hline 5 & $\begin{array}{l}\text { Escribano et al } \\
2009(5)\end{array}$ & inducible LIRKO & $\begin{array}{l}\text { Cre-loxP } \\
\text { system }\end{array}$ & 16 hours & $2 \mathrm{~g} / \mathrm{kg}$ dextrose i.p. & $\begin{array}{l}\mathrm{n}=10 \text { to } 20 \text { for each } \\
\text { group }\end{array}$ \\
\hline 6 & Ealey et al 2008 (6) & MIRKO (Muscle IRKO) & $\begin{array}{l}\text { Cre-loxP } \\
\text { system }\end{array}$ & ON & $2 \mathrm{~g} / \mathrm{kg}$ dextrose i.p. & $\begin{array}{l}\mathrm{n}=7 \text { to } 13 \text { for each } \\
\text { group }\end{array}$ \\
\hline 7 & $\begin{array}{l}\text { Okada et al } 2007 \\
(7)\end{array}$ & $\begin{array}{l}\beta I R K O(\beta \text {-cell IRKO), LIRKO } \\
\text { and } \beta \text { IRKO-LIRKO ( } 4-5 \text { weeks } \\
\text { old male mice) }\end{array}$ & $\begin{array}{l}\text { Cre-loxP } \\
\text { system }\end{array}$ & $\mathrm{ON}$ & $2 \mathrm{~g} / \mathrm{kg}$ dextrose i.p. & $\mathrm{n}=8$ for each group \\
\hline
\end{tabular}




\begin{tabular}{|c|c|c|c|c|c|c|}
\hline & & $\begin{array}{l}\beta I R K O \text { ( } 20 \text { weeks old, male } \\
\text { mice; chow and HFD) }\end{array}$ & & & & $\begin{array}{l}\mathrm{n}=9 \text { to } 16 \text { for each } \\
\text { group }\end{array}$ \\
\hline 8 & $\begin{array}{l}\text { Cohen et al } 2004 \\
\text { (8) }\end{array}$ & LIRKO (2-month-old mice) & $\begin{array}{l}\text { Cre-loxP } \\
\text { system }\end{array}$ & 16 hours & $2 \mathrm{~g} / \mathrm{kg}$ dextrose i.p. & $\begin{array}{l}n=17 \text { for control } \\
n=25 \text { for LIRKO }\end{array}$ \\
\hline \multirow[t]{2}{*}{9} & \multirow[t]{2}{*}{ Otani et al 2004 (9) } & $\beta I R K O-N o n-d i a b e t i c(N D)$ & \multirow[t]{2}{*}{$\begin{array}{l}\text { Cre-loxP } \\
\text { system }\end{array}$} & \multirow[t]{2}{*}{4 hours } & \multirow[t]{2}{*}{$2 \mathrm{~g} / \mathrm{kg}$ dextrose i.p. } & $\begin{array}{l}n=35 \text { for control, } \\
n=28 \text { for } \\
\beta \operatorname{IRKO}(N D)\end{array}$ \\
\hline & & $\beta$ IRKO-Diabetic (D) & & & & $\mathrm{n}=10$ for $\beta \operatorname{IRKO}(\mathrm{D})$ \\
\hline 10 & $\begin{array}{l}\text { Blueher et al } 2002 \\
\text { (10) }\end{array}$ & $\begin{array}{l}\text { FIRKO ( } 2 \text { month and 10-month- } \\
\text { old mice) }\end{array}$ & $\begin{array}{l}\text { Cre-loxP } \\
\text { system }\end{array}$ & 16 hours & $2 \mathrm{~g} / \mathrm{kg}$ dextrose i.p. & $\mathrm{n}=8$ for each group \\
\hline 11 & $\begin{array}{l}\text { Guerra et al } 2001 \\
\text { (11) }\end{array}$ & $\begin{array}{l}\text { BATIRKO ( } 3,6 \text { and 9-month-old } \\
\text { male and female mice) }\end{array}$ & $\begin{array}{l}\text { Cre-loxP } \\
\text { system }\end{array}$ & $\mathrm{ON}$ & $2 \mathrm{~g} / \mathrm{kg}$ dextrose i.p. & $\begin{array}{l}\mathrm{n}=10 \text { to } 20 \text { for each } \\
\text { group }\end{array}$ \\
\hline 12 & $\begin{array}{l}\text { Lauro et al } 1998 \\
\text { (12) }\end{array}$ & $\begin{array}{l}\text { Insulin receptor (Ins R) and Ins } \\
\text { R K1030 mutatnt }\end{array}$ & $\begin{array}{l}\text { Cre-loxP } \\
\text { system, }\end{array}$ & $\mathrm{ON}$ & $2 \mathrm{~g} / \mathrm{kg}$ dextrose i.p. & $\mathrm{n}=8$ for each group \\
\hline 13 & $\begin{array}{l}\text { Mauvais-Jarvis et } \\
\text { al } 2000 \text { (13) }\end{array}$ & $\begin{array}{l}\text { MIRKO, } \beta \text { IRKO and } \beta \text { IRKO- } \\
\text { MIRKO }(2 \text { and } 6 \text {-month-old } \\
\text { mice }\end{array}$ & $\begin{array}{l}\text { Cre-loxP } \\
\text { system }\end{array}$ & $\mathrm{ON}$ & $2 \mathrm{~g} / \mathrm{kg}$ dextrose i.p. & $\begin{array}{l}\mathrm{n}=28 \text { to } 32 \text { for each } \\
\text { group }\end{array}$ \\
\hline 14 & $\begin{array}{l}\text { Micheal et al } 2000 \\
\text { (14) }\end{array}$ & $\begin{array}{l}\text { LIRKO (2 and 6-month-old } \\
\text { mice) }\end{array}$ & $\begin{array}{l}\text { Cre-loxP } \\
\text { system }\end{array}$ & 16 hours & $2 \mathrm{~g} / \mathrm{kg}$ dextrose i.p. & $\mathrm{n}=8$ for each group \\
\hline 15 & $\begin{array}{l}\text { Wojtaszewski et al } \\
1999(15)\end{array}$ & MIRKO & $\begin{array}{l}\text { Cre-loxP } \\
\text { system }\end{array}$ & $\mathrm{ON}$ & $2 \mathrm{~g} / \mathrm{kg}$ dextrose i.p. & $\begin{array}{l}\mathrm{n}=7 \text { to } 8 \text { for each } \\
\text { group }\end{array}$ \\
\hline 16 & $\begin{array}{l}\text { Bruening et al } 1998 \\
\text { (16) }\end{array}$ & MIRKO & $\begin{array}{l}\text { Cre-loxP } \\
\text { system }\end{array}$ & $\mathrm{ON}$ & $2 \mathrm{~g} / \mathrm{kg}$ dextrose i.p. & $\mathrm{n}=8$ for each group \\
\hline
\end{tabular}


1090 Table 2: Details of the 6 papers used in the Insulin Degrading Enzyme (IDE) inhibition meta-analysis. All studies were carried out on rodent 1091 models.

\begin{tabular}{|c|c|c|c|c|c|}
\hline $\begin{array}{l}\text { Sr. } \\
\text { No. }\end{array}$ & Reference & Method used to inhibit IDE & $\begin{array}{l}\text { Fasting duration } \\
\text { before the GTT }\end{array}$ & $\begin{array}{l}\text { Glucose concentration/mode of } \\
\text { glucose infusion used in GTT }\end{array}$ & Sample size \\
\hline 1 & $\begin{array}{l}\text { Villa Perez et al } \\
2018 \text { (17) }\end{array}$ & Liver specific IDE knockout & 16 hours & $2 \mathrm{~g} / \mathrm{kg}$ dextrose given i.p. & $\begin{array}{l}\mathrm{n}=9 \text { to } 13 \text { for each } \\
\text { group }\end{array}$ \\
\hline 2 & $\begin{array}{l}\text { Deprez-Poulain et } \\
\text { al } 2018 \text { (18) }\end{array}$ & $\begin{array}{l}\text { Inhibition of catalytic site of IDE } \\
\text { using the inhibitor BDM } 44768\end{array}$ & 6 hours & $\begin{array}{l}1.5 \mathrm{~g} / \mathrm{kg} \text { glucose for IPGTT and } 2 \text { or } \\
3 \mathrm{~g} / \mathrm{kg} \text { glucose for OGTT }\end{array}$ & $\begin{array}{l}\mathrm{n}=4 \text { to } 7 \text { for each } \\
\text { group }\end{array}$ \\
\hline 3 & $\begin{array}{l}\text { Durham et al } 2015 \\
\text { (19) }\end{array}$ & $\begin{array}{l}\text { Inhibition of IDE using an N- } \\
\text { terminal exosite (NTE) }\end{array}$ & ON & $2 \mathrm{~g} / \mathrm{kg}$ dextrose given orally & $\mathrm{n}=6$ for each group \\
\hline 4 & $\begin{array}{l}\text { Maianti et al } 2014 \\
(20)\end{array}$ & $\begin{array}{l}\text { Inhibition of IDE using a non- } \\
\text { catalytic site binding inhibitor }\end{array}$ & 14 hours & $\begin{array}{l}1.5 \mathrm{~g} / \mathrm{kg} \text { glucose for IPGTT and } 3 \mathrm{~g} / \mathrm{kg} \\
\text { glucose for OGTT }\end{array}$ & $\begin{array}{l}\mathrm{n}=5 \text { to } 7 \text { for each } \\
\text { group }\end{array}$ \\
\hline 5 & $\begin{array}{l}\text { Abdul Hay et al } \\
2011(21)\end{array}$ & $\begin{array}{l}\text { IDE-KO created by Cre-lox } \\
\text { recombination }\end{array}$ & 6 to 9 hours & $1 \mathrm{~g} / \mathrm{kg}$ dextrose given i.p. & $\begin{array}{l}\mathrm{n}=10 \text { to } 12 \text { for each } \\
\text { group }\end{array}$ \\
\hline 6 & $\begin{array}{l}\text { Farris et al } 2003 \\
\text { (22) }\end{array}$ & $\begin{array}{l}\mathrm{IDE}^{-/-} \text {mice created by gene } \\
\text { trapping method }\end{array}$ & ON & $2 \mathrm{~g} / \mathrm{kg}$ dextrose given i.p. & $\begin{array}{l}\mathrm{n}=6\left(\mathrm{IDE}^{-/-}\right) \\
\mathrm{n}=4(\text { Control })\end{array}$ \\
\hline
\end{tabular}

1093 Table 3: Details of the 8 papers used in the Diazoxide (DZX) meta-analysis.

\begin{tabular}{|c|c|c|c|c|c|c|}
\hline $\begin{array}{l}\text { Sr. } \\
\text { No. }\end{array}$ & Study reference & $\begin{array}{l}\text { Concentration of diazoxide } \\
\text { used }\end{array}$ & Details of subjects/model & $\begin{array}{l}\text { Fasting } \\
\text { duration }\end{array}$ & GTT details & $\begin{array}{l}\text { Sample size for } \\
\text { GTT (placebo, } \\
\text { treatment) }\end{array}$ \\
\hline \multicolumn{7}{|c|}{ Studies on human subjects } \\
\hline 1 & $\begin{array}{l}\text { Brauner et al } \\
2016(23)\end{array}$ & 3.2 to $4.2 \mathrm{mg} / \mathrm{kg} / \mathrm{d}$ for $6 \mathrm{months}$ & $\begin{array}{l}\text { Children over the age of } 6 \text { with } \\
\text { hyperinsulinemia and obesity }\end{array}$ & ON & $\begin{array}{l}75 \mathrm{~g} \text { glucose given } \\
\text { to patients orally }\end{array}$ & $\begin{array}{l}\mathrm{n}=12 \text { to } 17 \text { for } \\
\text { each group }\end{array}$ \\
\hline
\end{tabular}




\begin{tabular}{|c|c|c|c|c|c|c|}
\hline 2 & $\begin{array}{l}\text { Ramanathan et al } \\
2011 \text { (24) }\end{array}$ & $6 \mathrm{mg} / \mathrm{kg}$ diazoxide & Healthy, young adults & ON & Mixed meal & $\begin{array}{l}\mathrm{n}=11 \text { for each } \\
\text { group }\end{array}$ \\
\hline 3 & $\begin{array}{l}\text { Van Boekel et al } \\
2008(25)\end{array}$ & $\begin{array}{l}\text { 50mg t.i.d (thrice in a day) for } 4 \\
\text { weeks and then dose increased } \\
\text { till } 300 \mathrm{mg} \text { t.i.d, total duration: } 6 \\
\text { months }\end{array}$ & Obese, men, age 30 to 50 years & $\mathrm{ON}$ & $\begin{array}{l}\text { Standardized } \\
\text { mixed meal }\end{array}$ & $\begin{array}{l}\mathrm{n}=18 \text { for each } \\
\text { group }\end{array}$ \\
\hline 4 & $\begin{array}{l}\text { Due et al } 2007 \\
(26)\end{array}$ & $\begin{array}{l}2 \mathrm{mg} / \mathrm{kg} / \text { day DZX or placebo for } \\
8 \text { weeks }\end{array}$ & $\begin{array}{l}35 \text { Overweight and obese men, } \\
\text { age } 23-54 \text { years }\end{array}$ & ON & $\begin{array}{l}75 \mathrm{~g} \text { glucose in } \\
300 \mathrm{~m} \text { water given } \\
\text { orally }\end{array}$ & $\begin{array}{l}\mathrm{n}=13(\mathrm{DZX}) \text { and } \\
\mathrm{n}=18 \text { (placebo) }\end{array}$ \\
\hline 5 & $\begin{array}{l}\text { Schreuder et al } \\
2005(27)\end{array}$ & 50/75/100 mg t.i.d for 6 days & $\begin{array}{l}\text { Healthy obese and non-obese } \\
\text { men, age } 30-50 \text { years }\end{array}$ & $\mathrm{ON}$ & $\begin{array}{l}\text { Standardized } \\
\text { mixed meal }\end{array}$ & $\begin{array}{l}\mathrm{n}=5 \text { (non-obese) } \\
\text { and } \mathrm{n}=12 \text { (obese) }\end{array}$ \\
\hline 6 & $\begin{array}{l}\text { Wigand and } \\
\text { Blackard } 1979 \\
(28)\end{array}$ & $5 \mathrm{mg} / \mathrm{kg} / \mathrm{d}, 7$ days & $\begin{array}{l}\text { Obese, non-diabetic subjects, age } \\
18-33\end{array}$ & ON & $\begin{array}{l}40 \mathrm{~g} / \mathrm{m}^{2} \text { body } \\
\text { surface area } \\
\text { glucose given } \\
\text { orally }\end{array}$ & $\mathrm{n}=10$ \\
\hline \multicolumn{7}{|c|}{ Studies on rodent models } \\
\hline 7 & $\begin{array}{l}\text { Matsuda et al } \\
2002(29)\end{array}$ & $30 \mathrm{mg} / \mathrm{kg} / \mathrm{day}$ for 6 weeks & $\begin{array}{l}\text { Male Wistar rats, control and STZ } \\
\text { induced diabetes }\end{array}$ & 12 hours & 2g/kg glucose i.p & $\begin{array}{l}\mathrm{n}=7 \text { for each } \\
\text { group }\end{array}$ \\
\hline 8 & $\begin{array}{l}\text { Leahy et al } 1994 \\
(30)\end{array}$ & $\begin{array}{l}30 \mathrm{mg} / \mathrm{kg} / \text { day, twice a day, for } 8- \\
12 \text { days }\end{array}$ & $\begin{array}{l}\text { Male Sprague-Dawley rats, } 3 \\
\text { groups-sham, Pancreatectomised } \\
\text { rats treated with water, } \\
\text { pancreatectomised rats treated } \\
\text { DZX }\end{array}$ & ON & $\begin{array}{l}3.5 \mathrm{~g} / \mathrm{kg} \text { oral } \\
\text { gavage }\end{array}$ & $\begin{array}{l}\mathrm{n}=4 \text { for each } \\
\text { group }\end{array}$ \\
\hline
\end{tabular}


1096 Table 4: Details of the 10 papers used in the Octreotide (OCT) meta-analysis. All the papers included studies on human subjects.

\begin{tabular}{|c|c|c|c|c|c|c|}
\hline $\begin{array}{l}\text { Sr. } \\
\text { No. }\end{array}$ & Study reference & $\begin{array}{l}\text { Concentration of octreotide } \\
\text { used }\end{array}$ & Details of subjects/model & $\begin{array}{l}\text { Fasting } \\
\text { duration }\end{array}$ & GTT details & $\begin{array}{l}\text { Sample size for } \\
\text { GTT (placebo, } \\
\text { treatment) }\end{array}$ \\
\hline 1 & $\begin{array}{l}\text { Madsen et al } 2011 \\
(31)\end{array}$ & $\begin{array}{l}\text { Somatostatin analog (SA) alone: } \\
\text { Octreotide } 10-30 \mathrm{mg} / 4 \text { weeks OR } \\
\text { Lanreotide } 80 \mathrm{mg} / 4 \text { weeks } \\
\text { Co-treatment: } \\
\text { Octreotide } 6.7-20 \mathrm{mg} / 4 \text { weeks OR } \\
\text { Lanreotide } 24-60 \mathrm{mg} / 4 \text { weeks } \\
\text { AND } \\
\text { Pegvisomat } 30-60 \mathrm{mg} / 4 \text { weeks }\end{array}$ & $\begin{array}{l}18 \text { Acromegalic patients (age } \\
54 \pm 3 \text { years) }\end{array}$ & $\mathrm{ON}$ & $\begin{array}{l}75 \mathrm{~g} \text { glucose given } \\
\text { orally }\end{array}$ & $\begin{array}{l}n=6 \text { SA only } \\
n=12 \text { SA }+P\end{array}$ \\
\hline 2 & $\begin{array}{l}\text { Breckenbridge et } \\
\text { al } 2007 \text { (32) }\end{array}$ & $\begin{array}{l}\text { Octreotide (30ng/kg.min) with } \\
\text { GH + } \\
\text { 1. Saline (treatment for our } \\
\text { purpose) } \\
\text { 2. Insulin (control for our } \\
\text { purpose) }\end{array}$ & $\begin{array}{l}14 \text { Healthy adults (BMI } 23 \pm 2.9 \\
\text { Age } 29 \pm 5 \text { years) }\end{array}$ & $\mathrm{ON}$ & $22.5 \mu \mathrm{mol} / \mathrm{kg}$ & $\begin{array}{l}\mathrm{n}=8 \text { male } \\
\mathrm{n}=6 \text { female }\end{array}$ \\
\hline 3 & $\begin{array}{l}\text { Ronchi et al } 2004 \\
\text { (33) }\end{array}$ & $\begin{array}{l}\text { 1. Lanreotide (Slow Release)- } \\
30 \mathrm{mg} \text { im injection every } 14 \text { days } \\
\text { for } 19 \pm 16 \text { months } \\
\text { 2. Octreotide (Long Acting } \\
\text { Release)-20mg im injection } \\
\text { every } 28 \text { days for } 21 \pm 10 \text { months }\end{array}$ & $\begin{array}{l}10 \text { acromegalic patients ( } 6 \text { men } \\
\text { and } 4 \text { women; age } 46 \pm 16 \text { years; } \\
\text { BMI } 29 \pm 5)\end{array}$ & $\mathrm{ON}$ & not mentioned & $\begin{array}{l}\mathrm{n}=6 \text { male } \\
\mathrm{n}=4 \text { female }\end{array}$ \\
\hline 4 & $\begin{array}{l}\text { Parkinson et al } \\
2002 \text { (34) }\end{array}$ & $\begin{array}{l}\text { 1. Octreotide }(50 \mu \mathrm{g} s \mathrm{sc} \text { t.i.d) for } 7 \\
\text { days } \\
\text { 2. Pegvisomant }(20 \mathrm{mg} / \text { day sc) } \\
\text { for } 7 \text { days }\end{array}$ & $\begin{array}{l}6 \text { healthy, male volunteers (age } \\
21-63 \text { years), studied on } 3 \\
\text { separate occasions }\end{array}$ & $\mathrm{ON}$ & $\begin{array}{l}75 \mathrm{~g} \text { glucose given } \\
\text { orally }\end{array}$ & $\mathrm{n}=6$ male \\
\hline
\end{tabular}




\begin{tabular}{|c|c|c|c|c|c|c|}
\hline 5 & $\begin{array}{l}\text { Giustina et al } \\
1991(35)\end{array}$ & $\begin{array}{l}\text { T2D patients received either of } \\
\text { the four treatments } \\
\text { a. Insulin } 0.1 \mathrm{U} / \mathrm{kg} \\
\text { b. Octreotide } 25 \mu \mathrm{g} \\
\text { c. Oct } 50 \mu \mathrm{g} \\
\text { d. Oct } 100 \mu \mathrm{g} \text { with insulin }\end{array}$ & $\begin{array}{l}8 \text { overweight/obese T2D patients } \\
\text { (age } 53.4 \pm 4.2 \text { years) }\end{array}$ & $\mathrm{ON}$ & Mixed meal & $\begin{array}{l}\mathrm{n}=8(7 \text { female and } \\
1 \text { male })\end{array}$ \\
\hline 6 & $\begin{array}{l}\text { Candrina and } \\
\text { Giustina } 1998 \\
(36)\end{array}$ & $\begin{array}{l}\text { Type } 2 \text { diabetes patients } \\
\text { received } 0.5 \mathrm{U} / \mathrm{kg} / \text { day divided } \\
\text { into } 2 \text { subcutaneous injections }\end{array}$ & $\begin{array}{l}5 \text { T2D patients (age } 56 \pm 4 \text { years) } \\
\text { duration of diabetes ranged from } \\
13 \text { to } 25 \text { years }\end{array}$ & $\mathrm{ON}$ & 300 kcal breakfast & $\begin{array}{l}\mathrm{n}=5 \text { ( } 3 \text { male and } 2 \\
\text { female) }\end{array}$ \\
\hline 7 & $\begin{array}{l}\text { Williams et al } \\
1988 \text { (37) }\end{array}$ & $\begin{array}{l}\text { Type } 2 \text { diabetes patients } \\
\text { received } 50 \mu \mathrm{g} \text { OCT, thrice a } \\
\text { day, subcutaneously, for } 3 \text { days }\end{array}$ & $\begin{array}{l}7 \text { T2D patients (age } 51-73 \text { years, } \\
\text { mean } 67 \text { years), duration of } \\
\text { diabetes ranged from ( } 6 \text { months to } \\
4 \text { years, mean } 2.5 \text { years) }\end{array}$ & $\mathrm{ON}$ & $\begin{array}{l}\text { Standardised } \\
\text { breakfast }\end{array}$ & $\begin{array}{l}\mathrm{n}=7 \text { ( } 4 \text { males and } \\
3 \text { females) }\end{array}$ \\
\hline 8 & $\begin{array}{l}\text { Johnston et al } \\
1986 \text { (38) }\end{array}$ & $\begin{array}{l}50 \mu \mathrm{g} \text { OCT administered } \\
\text { subcutaneously, twice a day in } \\
\text { diabetic and nondiabetic patients }\end{array}$ & $\begin{array}{l}6 \text { normal and } 5 \text { type } 2 \text { diabetic } \\
\text { subjects (age range not given) }\end{array}$ & $\mathrm{ON}$ & $\begin{array}{l}\text { Standardised } \\
\text { meals }\end{array}$ & $\begin{array}{l}\mathrm{n}=6 \text { (normal, } \\
\text { male) } \\
\mathrm{n}=5(\mathrm{~T} 2 \mathrm{D})\end{array}$ \\
\hline 9 & $\begin{array}{l}\text { Davies et al } 1986 \\
(39)\end{array}$ & $\begin{array}{l}50 \mu \mathrm{g} \text { OCT administered } \\
\text { subcutaneously, twice a day in } \\
\text { diabetic patients }\end{array}$ & $\begin{array}{l}5 \text { T2D patients (mean age } 49 \\
\text { years; duration of diabetes ranged } \\
\text { from } 3 \text { to } 10 \text { years, with a mean of } \\
6 \text { years) }\end{array}$ & $\mathrm{ON}$ & $\begin{array}{l}\text { Standardised } \\
\text { breakfast }\end{array}$ & $\begin{array}{l}\mathrm{n}=5 \text { (male, } \\
\text { diabetic) }\end{array}$ \\
\hline 10 & $\begin{array}{l}\text { Williams et al } \\
1986(40)\end{array}$ & $\begin{array}{l}5-100 \mu \mathrm{g} \text { OCT administered } \\
\text { subcutaneously in T2D patients } \\
\text { twice a day } \\
\text { Concentrations used: } \\
50 \mu \mathrm{g} \text { in normal } \\
5,100 \mu \mathrm{g} \text { in } \mathrm{T} 2 \mathrm{D}\end{array}$ & $\begin{array}{l}5 \text { normal and } 5 \text { T2D patients (age } \\
50 \text { to } 65 \text { years }\end{array}$ & $\mathrm{ON}$ & $\begin{array}{l}\text { Standardised } \\
\text { breakfast }\end{array}$ & $\begin{array}{l}\mathrm{n}=5(\text { normal }) \\
\mathrm{n}=5(\mathrm{~T} 2 \mathrm{D})\end{array}$ \\
\hline
\end{tabular}


1098

1099

1100

1101

1102

1103

1104

1105

1106

1107

1108

1109

1110

1111

1112

1113

1114

1115

1116

1117

1118

1119

1120

1121

1122

1123

1124

1125

1126

1127

1128

1129

1130

1131

1132

1133

1134

1135

1136

1137

1138

1139

1140

1141

1142

1143

\section{References (Supplementary information 1)}

1. Sakaguchi M, Fujisaka S, Cai W, Winnay JN, Konishi M, O'Neill BT, et al. Adipocyte Dynamics and Reversible Metabolic Syndrome in Mice with an Inducible Adipocyte-Specific Deletion of the Insulin Receptor. Cell Metab. 2017;25(2):448-62.

2. Softic S, Boucher J, Solheim MH, Fujisaka S, Haering MF, Homan EP, et al. Lipodystrophy due to adipose tissue-specific insulin receptor knockout results in progressive NAFLD. Diabetes. 2016;65(8):2187-200.

3. Haas JT, Miao J, Chanda D, Wang Y, Zhao E, Haas ME, et al. Hepatic Insulin Signaling Is Required for Obesity-Dependent Expression of SREBP-1c mRNA but Not for Feeding-Dependent Expression. Cell Metab [Internet]. 2012 Jun;15(6):873-84. Available from: http://linkinghub.elsevier.com/retrieve/pii/S1550413112001957

4. Kawamori D, Kurpad AJ, Hu J, Liew CW, Shih JL, Ford EL, et al. Insulin Signaling in a Cells Modulates Glucagon Secretion In Vivo. Cell Metab [Internet]. 2009 Apr;9(4):350-61. Available from: http://www.ncbi.nlm.nih.gov/pmc/articles/PMC2694613/pdf/nihms109119.pdf

5. Escribano O, Gómez-Hernández A, Díaz-Castroverde S, Nevado C, García G, Otero YF, et al. Insulin receptor isoform A confers a higher proliferative capability to pancreatic beta cells enabling glucose availability and IGF-I signaling. Mol Cell Endocrinol. 2015;

6. Ealey KN, Lu S, Lau D, Archer MC. Reduced susceptibility of muscle-specific insulin receptor knockout mice to colon carcinogenesis. Am J Physiol Gastrointest Liver Physiol. 2008;294(3):G679-86.

7. Okada T, Liew CW, Hu J, Hinault C, Michael MD, Krtzfeldt J, et al. Insulin receptors in beta-cells are critical for islet compensatory growth response to insulin resistance. Proc Natl Acad Sci U S A [Internet]. 2007 May 22;104(21):8977-82. Available from: http://www.ncbi.nlm.nih.gov/pubmed/17416680

8. Cohen SE, Tseng Y-H, Michael MD, Kahn CR. Effects of insulin-sensitising agents in mice with hepatic insulin resistance. Diabetologia [Internet]. 2004 Mar 1;47(3):407-11. Available from: http://link.springer.com/10.1007/s00125-003-1320-4

9. Otani K. Reduced -cell mass and altered glucose sensing impair insulin-secretory function in IRKO mice. AJP Endocrinol Metab. 2003;

10. Blüher M, Michael MD, Peroni OD, Ueki K, Carter N, Kahn BB, et al. Adipose tissue selective insulin receptor knockout protects against obesity and obesity-related glucose intolerance. Dev Cell. 2002;

11. Guerra C, Navarro P, Valverde AM, Arribas M, Brüning J, Kozak LP, et al. Brown adipose tissue specific insulin receptor knockout shows diabetic phenotype without insulin resistance. J Clin Invest. 2001;108(8):1205-13.

12. Lauro D, Kido Y, Castle a L, Zarnowski MJ, Hayashi H, Ebina Y, et al. Impaired glucose tolerance in mice with a targeted impairment of insulin action in muscle and adipose tissue. Nat Genet. 1998;20(3):294-8.

13. Mauvais-Jarvis F, Virkamaki A, Michael MD, Winnay JN, Zisman A, Kulkarni RN, et al. A model to explore the interaction between muscle insulin resistance and beta-cell dysfunction in the development of type 2 diabetes. Diabetes. 2000;

14. Dodson Michael M, Kulkarni RN, Postic C, Previs SF, Shulman GI, Magnuson MA, et al. Loss of Insulin Signaling in Hepatocytes Leads to Severe Insulin Resistance and Progressive Hepatic Dysfunction. Mol Cell. 2000;6:87-97.

15. Wojtaszewski JFP, Higaki Y, Hirshman MF, Michael MD, Dufresne SD, Kahn CR, et al. Exercise modulates postreceptor insulin signaling and glucose transport in muscle-specific insulin receptor knockout mice. J Clin Invest. 1999;

16. Brüning JC, Michael MD, Winnay JN, Hayashi T, Hörsch D, Accili D, et al. A muscle-specific insulin 
receptor knockout exhibits features of the metabolic syndrome of NIDDM without altering glucose tolerance. Mol Cell. 1998;

17. Villa-Pérez P, Merino B, Fernández-Díaz CM, Cidad P, Lobatón CD, Moreno A, et al. Liver-specific ablation of insulin-degrading enzyme causes hepatic insulin resistance and glucose intolerance, without affecting insulin clearance in mice. Metabolism [Internet]. 2018;88:1-11. Available from: https://www.sciencedirect.com/science/article/pii/S0026049518301690

18. Deprez-Poulain R, Hennuyer N, Bosc D, Liang WG, Enée E, Marechal X, et al. Catalytic site inhibition of insulin-degrading enzyme by a small molecule induces glucose intolerance in mice. Nat Commun. $2015 ; 6$.

19. Durham TB, Toth JL, Klimkowski VJ, Cao JXC, Siesky AM, Alexander-Chacko J, et al. Dual exositebinding inhibitors of insulin-degrading enzyme challenge its role as the primary mediator of insulin clearance in vivo. J Biol Chem. 2015;290(33):20044-59.

20. Maianti JP, McFedries A, Foda ZH, Kleiner RE, Du XQ, Leissring MA, et al. Anti-diabetic activity of insulin-degrading enzyme inhibitors mediated by multiple hormones. Nature [Internet]. $2014 \mathrm{Jul}$ 21;511(7507):94-8. Available from: http://www.nature.com/articles/nature13297

21. Abdul-Hay SO, Kang D, McBride M, Li L, Zhao J, Leissring MA. Deletion of insulin-degrading enzyme elicits antipodal, age-dependent effects on glucose and insulin tolerance. PLoS One [Internet]. 2011;6(6):e20818. Available from: http://www.ncbi.nlm.nih.gov/pubmed/21695259

22. Farris W, Mansourian S, Chang Y, Lindsley L, Eckman EA, Frosch MP, et al. Insulin-degrading enzyme regulates the levels of insulin, amyloid beta-protein, and the beta-amyloid precursor protein intracellular domain in vivo. Proc Natl Acad Sci U S A [Internet]. 2003;100(7):4162-7. Available from: http://www.ncbi.nlm.nih.gov/pubmed/12634421\%5Cnhttp://www.ncbi.nlm.nih.gov/pubmed/12634421

23. Brauner R, Serreau R, Souberbielle JC, Pouillot M, Grouazel S, Recasens C, et al. Diazoxide in children with obesity after hypothalamic-pituitary lesions: A randomized, placebo-controlled trial. J Clin Endocrinol Metab. 2016;101(12):4825-33.

24. Ramanathan RP, Arbeláez AM, Cryer PE. Partial inhibition of insulin secretion results in glucose intolerance but not hyperglucagonemia. Diabetes. 2011;60(4):1324-8.

25. van Boekel G, Loves S, van Sorge A, Ruinemans-Koerts J, Rijnders T, de Boer H. Weight loss in obese men by caloric restriction and high-dose diazoxide-mediated insulin suppression. Diabetes, Obes Metab. 2008;10(12):1195-203.

26. Due A, Flint A, Eriksen G, Møller B, Raben A, Hansen JB, et al. No effect of inhibition of insulin secretion by diazoxide on weight loss in hyperinsulinaemic obese subjects during an 8-week weight-loss diet. Diabetes, Obes Metab. 2007;9(4):566-74.

27. Schreuder T, Karreman M, Rennings A, Ruinemans-Koerts J, Jansen M, de Boer H. Diazoxidemediated insulin suppression in obese men: a dose-response study. Diabetes Obes Metab [Internet]. 2005 May;7(3):239-45. Available from: http://www.ncbi.nlm.nih.gov/pubmed/15811140

28. Wigand JP, Blackard WG. Downregulation of insulin receptors in obese man. Diabetes. 1979;28(4):287-91.

29. Matsuda M, Kawasaki F, Mikami Y, Takeuchi Y, Saito M, Eto M, et al. Rescue of beta-cell exhaustion by diazoxide after the development of diabetes mellitus in rats with streptozotocin-induced diabetes. Eur J Pharmacol. 2002;453(1):141-8.

30. Leahy JL, Bumbalo LM, Chen C. Diazoxide causes recovery of beta-cell glucose responsiveness in $90 \%$ pancreatectomized diabetic rats. Diabetes [Internet]. 1994 Feb;43(2):173-9. Available from: http://doi.wiley.com/10.1046/j.1464-5491.1999.00150.x

31. Madsen M, Poulsen PL, Ørskov H, Møller N, Jørgensen JOL. Cotreatment with pegvisomant and a Somatostatin Analog (SA) in SA-responsive acromegalic patients. J Clin Endocrinol Metab. 2011;96(8):2405-13. 
1191
32. Breckenridge SM, Cooperberg BA, Arbelaez AM, Patterson BW, Cryer PE. Glucagon, in concert with insulin, supports the postabsorptive plasma glucose concentration in humans. Diabetes. 2007;56(10):2442-8.

33. Ronchi C, Epaminonda P, Cappiello V, Beck-Peccoz P, Arosio M. Effects of two different somatostatin analogs on glucose tolerance in acromegaly. J Endocrinol Invest [Internet]. 2002 Jun 22;25(6):502-7. Available from: http://link.springer.com/10.1007/BF03345491

34. Parkinson C, Drake WM, Roberts ME, Meeran K, Besser GM, Trainer PJ. A comparison of the effects of pegvisomant and octreotide on glucose, insulin, gastrin, cholecystokinin, and pancreatic polypeptide responses to oral glucose and a standard mixed meal. J Clin Endocrinol Metab. 2002;87(4):1797-804.

35. Giustina A, Girelli A, Buffoli MG, Cimino A, Legati F, Valentini U, et al. Low-dose octreotide is able to cause a maximal inhibition of the glycemic responses to a mixed meal in obese type 2 diabetic patients treated with insulin. Diabetes Res Clin Pract. 1991;14(1):47-54.

36. Candrina R, Gussago A, Giustina G. Effect of a new long-acting somatostatin analogue (SMS 201-995) on glycemic and hormonal response to a mixed meal in acromegalic patients. J Endocrinol Invest. 1988;11(1):21-6.

37. Williams G, Fuessl HS, Burrin JM, Chilvers E, Bloom SR. Postprandial glycaemic effects of a longacting somatostatin analogue (octreotide) in non-insulin dependent diabetes mellitus. Horm Metab Res. 1988;20(3):168-70.

38. Johnston DG, Davies RR, Alberti KGMM, Miller M, Turner SJ, Watson M, et al. Effects of SMS 201995 on intermediary metabolism and endocrine status in normal and diabetic humans. Am J Med. 1986;81(6 SUPPL. 2):88-93.

39. Davies RR, Miller M, Turner SJ, Watson M, McGill A, Orskov H, et al. Effects of somatostatin analogue SMS 201-995 in non-insulin-dependent diabetes. Clin Endocrinol (Oxf). 1986;25(6):739-47.

40. Williams G, Fuessl H, Kraenzlin M, Bloom SR. Postprandial effects of SMS 201-995 on gut hormones and glucose tolerance. Scand J Gastroenterol. 1986;21(S119):73-83. 


\section{Supplementary information 2}

\section{A generalized CSS model to make predictions testable in population data}

1220 A number of models of glucose regulation exist in literature. We use a simple model

1221 assuming the following. The plasma glucose level $G$ increases by two processes namely

1222 absorption from gut and glucose production by the liver. We assume the gut absorption Gt to

1223 be independent of standing plasma glucose as well as insulin, whereas liver glucose

1224 production has a maximum rate $L$ which has two feedback inhibitors namely direct feedback

1225 inhibition by glucose and that by standing plasma insulin which depends upon the insulin

1226 sensitivity of liver. Glucose clearance has two mechanisms namely insulin independent and

1227 insulin dependent. The plasma insulin $I$ is a balance between insulin release by pancreatic

1228 beta cells, the rate being a function of plasma glucose and a rate of insulin degradation which

1229 is directly proportional to standing plasma insulin level. We assume all relationships to be

1230 linear and use the model framework of Chawla et al 2018 (1).

$$
\begin{gathered}
\frac{d G}{d t}=G t+L-K_{1} \cdot G-I_{S E N S} \cdot K_{2} \cdot I \\
\frac{d I}{d t}=K_{3} \cdot G-d . I
\end{gathered}
$$

1231 Where $K_{l}$ is a rate constant for glucose uptake by tissues as well as direct feedback inhibition 1232 of liver glucose production, $K_{2}$ a rate constant for insulin mediated inhibition of liver glucose 1233 production as well as insulin mediated glucose uptake, both of which are assumed to be a 1234 function of insulin sensitivity $I_{S E N S}$ which is assumed to be unity normally and decreases with 1235 insulin resistance. $K_{3}$ is the rate constant for glucose stimulated insulin secretion and $d$ the 1236 rate of insulin clearance.

1237 We use simulations with normally distributed errors to study how the correlation between 1238 plasma glucose and insulin is affected by the parameters as well as by the standard deviation 1239 of errors. We use the errors additively or multiplicatively. For simulations using additive 1240 errors, we add normally distributed error terms $e_{1}$ and $e_{2}$ to both the equations.

$$
\frac{d G}{d t}=L-K_{1} \cdot G-I_{S E N S} \cdot K_{2} \cdot I+e_{1}
$$




$$
\frac{d I}{d t}=K_{3} \cdot G-d . I+e_{2}
$$

1243 For simulations using multiplicative error, we give normal distributions to $K_{1}, K_{2}, K_{3}$ and

$1244 I_{S E N S}$. Realistic ranges for the parameters are taken from Chawla et al 2018(1).

1245 Simulations show that in a additive error model, as long as the parameters of glucose insulin

1246 relationship are the same, the regression correlation parameters for glucose insulin

1247 relationship are not significantly different during fasting steady state $(G t=0)$ and at any time

1248 post meal $(G t>0)$. The only difference is in the range of glucose and insulin distribution

1249 (figure 1)

1250

1251

1252

1253

1254

1255 In simulations with multiplicative errors, the post meal glucose insulin correlation was

1256 always weaker than the fasting steady state correlation (figure 2). This is the likely result of

1257 the errors growing in proportion to larger values of glucose and insulin, and also due to an

1258 additional variable, gut absorption being incorporated in the model. 
1259

1260

1261

1262

1263

1264

1265

1266

1267

1268

1269

1270

1271

1272

1273

1274

1275

1276

1277

1278

1279

1280

1281

1282

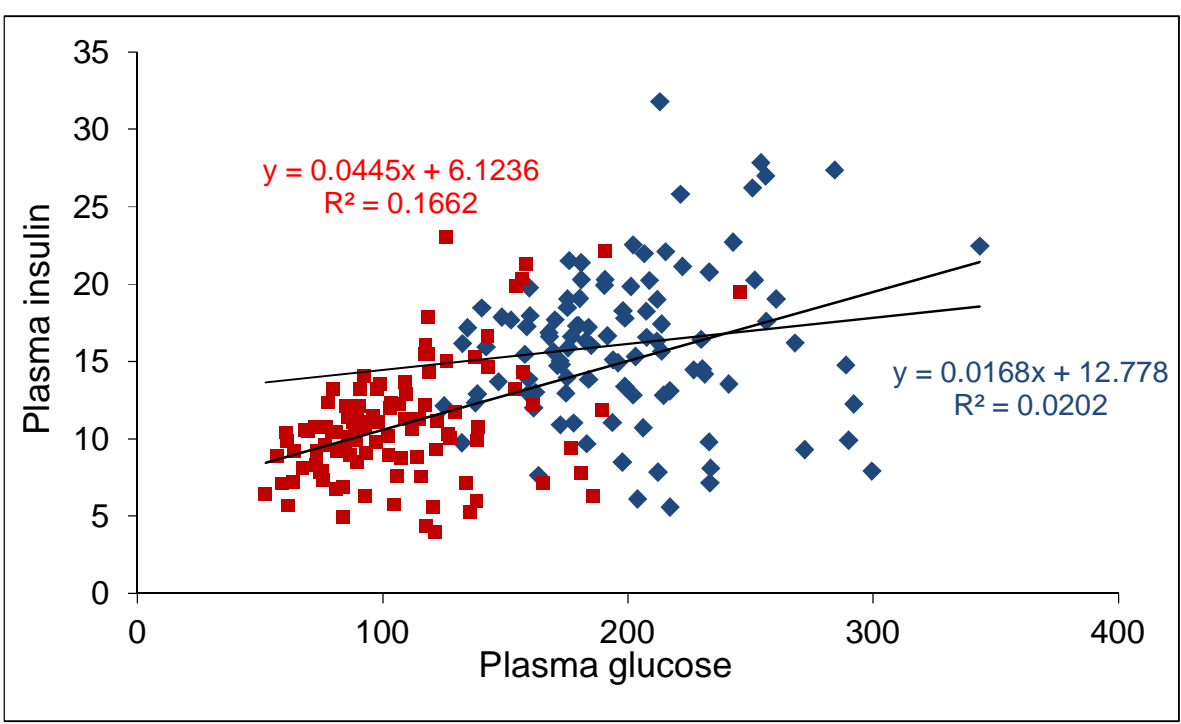

Figure 2: The glucose insulin scatter in a fasting steady state (red squares) and at a post meal arbitrary but constant time point (blue diamonds) in a multiplicative error model. A sample result is shown in which the mean (standard deviations) of the parameters were $K_{I}=0.1(0.02), K_{2}=0.9(0.5), I_{\text {SENS }}$ is randomized between 0.1 and 1 $K_{3}=0.0015(0.0002)$ and $d=0.15(0.005)$. In all the simulations the correlation coefficient and regression slopes of the post meal scatters were less than or equal to the corresponding fasting parameters. This contrasts the epidemiological patterns in which the fasting correlations are substantially weaker than the post meal correlations (main text Table 7 figure 10).

The results were not sensitive to parameter changes as long as $\mathrm{G}$ and I were positive. We can confidently make a generalization that as long as the model parameters remain the same, the glucose insulin correlation in steady state is stronger or equal to the post meal correlation. Logically and intuitively sound, this generalization is unlikely to be specific to a particular form of equations based on the assumptions of the CSS class of models.

The simulation results contrast with real life data in which the steady state correlation and regression slope between glucose and insulin is observed to be substantially weaker than the post meal relations at any point in time. This indicates that the parameters of glucose insulin relationship in steady state are substantially different from the post meal parameters, or glucose insulin relationship in steady state is qualitatively different from that in the perturbed state.

\section{References (Supplementary information 2)}

1. Chawla S, Pund A, B. V, Kulkarni S, Diwekar-Joshi M, Watve M. Inferring causal pathways among three or more variables from steady-state correlations in a homeostatic system. Ruscica M, editor. PLoS One [Internet]. 2018 Oct 11;13(10):e0204755. Available from: http://dx.plos.org/10.1371/journal.pone.0204755 
Supplementary information 3:

1. PRISMA 2009 Checklist for the Insulin Receptor Knockout meta-analysis.

\begin{tabular}{|c|c|c|c|}
\hline Section/topic & \# & Checklist item & Reported on page \# \\
\hline \multicolumn{4}{|l|}{ TITLE } \\
\hline Title & 1 & $\begin{array}{l}\text { Identify the report as a systematic review, meta-analysis, or } \\
\text { both. }\end{array}$ & $\begin{array}{l}\text { Not applicable (NA) since meta-analyses } \\
\text { is one of the methods used to address the } \\
\text { question and not the only method. }\end{array}$ \\
\hline \multicolumn{4}{|l|}{ ABSTRACT } \\
\hline Structured summary & 2 & $\begin{array}{l}\text { Provide a structured summary including, as applicable: } \\
\text { background; objectives; data sources; study eligibility } \\
\text { criteria, participants, and interventions; study appraisal and } \\
\text { synthesis methods; results; limitations; conclusions and } \\
\text { implications of key findings; systematic review registration } \\
\text { number. }\end{array}$ & 2 \\
\hline \multicolumn{4}{|l|}{ INTRODUCTION } \\
\hline Rationale & 3 & $\begin{array}{l}\text { Describe the rationale for the review in the context of what is } \\
\text { already known. }\end{array}$ & Page 5, Line 50 \\
\hline Objectives & 4 & $\begin{array}{l}\text { Provide an explicit statement of questions being addressed } \\
\text { with reference to participants, interventions, comparisons, } \\
\text { outcomes, and study design (PICOS). }\end{array}$ & Page 6 \\
\hline METHODS & & & \\
\hline
\end{tabular}




\begin{tabular}{|c|c|c|c|}
\hline Protocol and registration & 5 & $\begin{array}{l}\text { Indicate if a review protocol exists, if and where it can be } \\
\text { accessed (e.g., Web address), and, if available, provide } \\
\text { registration information including registration number. }\end{array}$ & NA \\
\hline Eligibility criteria & 6 & $\begin{array}{l}\text { Specify study characteristics (e.g., PICOS, length of follow- } \\
\text { up) and report characteristics (e.g., years considered, } \\
\text { language, publication status) used as criteria for eligibility, } \\
\text { giving rationale. }\end{array}$ & NA \\
\hline Information sources & 7 & $\begin{array}{l}\text { Describe all information sources (e.g., databases with dates of } \\
\text { coverage, contact with study authors to identify additional } \\
\text { studies) in the search and date last searched. }\end{array}$ & $\begin{array}{l}\text { Page 7: Table 1; } \\
\text { Page 51: Supplementary information } 1\end{array}$ \\
\hline Search & 8 & $\begin{array}{l}\text { Present full electronic search strategy for at least one } \\
\text { database, including any limits used, such that it could be } \\
\text { repeated. }\end{array}$ & $\begin{array}{l}\text { Page 7: Table 1; } \\
\text { Page 51-52: Supplementary information } 1\end{array}$ \\
\hline Study selection & 9 & $\begin{array}{l}\text { State the process for selecting studies (i.e., screening, } \\
\text { eligibility, included in systematic review, and, if applicable, } \\
\text { included in the meta-analysis). }\end{array}$ & $\begin{array}{l}\text { Page 7: Table 1; } \\
\text { Page 51-52: Supplementary information } 1\end{array}$ \\
\hline Data collection process & 10 & $\begin{array}{l}\text { Describe method of data extraction from reports (e.g., piloted } \\
\text { forms, independently, in duplicate) and any processes for } \\
\text { obtaining and confirming data from investigators. }\end{array}$ & $\begin{array}{l}\text { Data extraction: Page 51: Supplementary } \\
\text { information } 1 \\
\text { No process for obtaining and confirming } \\
\text { data from investigators, only published } \\
\text { data used. }\end{array}$ \\
\hline Data items & 11 & $\begin{array}{l}\text { List and define all variables for which data were sought (e.g., } \\
\text { PICOS, funding sources) and any assumptions and } \\
\text { simplifications made. }\end{array}$ & Page 51-52: Supplementary information 1 \\
\hline $\begin{array}{l}\text { Risk of bias in } \\
\text { individual studies }\end{array}$ & 12 & $\begin{array}{l}\text { Describe methods used for assessing risk of bias of individual } \\
\text { studies (including specification of whether this was done at } \\
\text { the study or outcome level), and how this information is to be } \\
\text { used in any data synthesis. }\end{array}$ & NA \\
\hline
\end{tabular}




\begin{tabular}{|c|c|c|c|}
\hline Summary measures & 13 & $\begin{array}{l}\text { State the principal summary measures (e.g., risk ratio, } \\
\text { difference in means). }\end{array}$ & $\begin{array}{l}\text { Difference in means with the } 95 \% \\
\text { Confidence Intervals of the means. (Page } \\
\text { 51-52: Supplementary information 1) }\end{array}$ \\
\hline Synthesis of results & 14 & $\begin{array}{l}\text { Describe the methods of handling data and combining results } \\
\text { of studies, if done, including measures of consistency (e.g., } \\
\mathrm{I}^{2} \text { ) for each meta-analysis. }\end{array}$ & $\mathrm{NA}$ \\
\hline $\begin{array}{l}\text { Risk of bias across } \\
\text { studies }\end{array}$ & 15 & $\begin{array}{l}\text { Specify any assessment of risk of bias that may affect the } \\
\text { cumulative evidence (e.g., publication bias, selective } \\
\text { reporting within studies). }\end{array}$ & NA \\
\hline Additional analyses & 16 & $\begin{array}{l}\text { Describe methods of additional analyses (e.g., sensitivity or } \\
\text { subgroup analyses, meta-regression), if done, indicating } \\
\text { which were pre-specified. }\end{array}$ & NA \\
\hline \multicolumn{4}{|l|}{ RESULTS } \\
\hline Study selection & 17 & $\begin{array}{l}\text { Give numbers of studies screened, assessed for eligibility, and } \\
\text { included in the review, with reasons for exclusions at each } \\
\text { stage, ideally with a flow diagram. }\end{array}$ & Page 7: Table 1; \\
\hline Study characteristics & 18 & $\begin{array}{l}\text { For each study, present characteristics for which data were } \\
\text { extracted (e.g., study size, PICOS, follow-up period) and } \\
\text { provide the citations. }\end{array}$ & Page 51-52: Supplementary information 1 \\
\hline $\begin{array}{l}\text { Risk of bias within } \\
\text { studies }\end{array}$ & 19 & $\begin{array}{l}\text { Present data on risk of bias of each study and, if available, } \\
\text { any outcome level assessment (see item 12). }\end{array}$ & NA \\
\hline $\begin{array}{l}\text { Results of individual } \\
\text { studies }\end{array}$ & 20 & $\begin{array}{l}\text { For all outcomes considered (benefits or harms), present, for } \\
\text { each study: (a) simple summary data for each intervention } \\
\text { group (b) effect estimates and confidence intervals, ideally } \\
\text { with a forest plot. }\end{array}$ & $\begin{array}{l}\text { (a) Pages } 51 \text { to } 52 \text { : Supplementary } \\
\text { information } 1 \\
\text { (b) Figures } 1 \text { to } 4 \text { in the paper } \\
\text { (c) Table } 2 \text { in the paper }\end{array}$ \\
\hline Synthesis of results & 21 & $\begin{array}{l}\text { Present results of each meta-analysis done, including } \\
\text { confidence intervals and measures of consistency. }\end{array}$ & Pages $8-15$ in the paper \\
\hline
\end{tabular}




\begin{tabular}{||l||l||l||l||}
\hline $\begin{array}{l}\text { Risk of bias across } \\
\text { studies }\end{array}$ & 22 & $\begin{array}{l}\text { Present results of any assessment of risk of bias across studies } \\
\text { see Item 15). }\end{array}$ & NA \\
\hline Additional analysis & 23 & $\begin{array}{l}\text { Give results of additional analyses, if done (e.g., sensitivity or } \\
\text { subgroup analyses, meta-regression [see Item 16]). }\end{array}$ & NA \\
\hline \hline DISCUSSION & 24 & $\begin{array}{l}\text { Summarize the main findings including the strength of } \\
\text { evidence for each main outcome; consider their relevance to } \\
\text { key groups (e.g., healthcare providers, users, and policy } \\
\text { makers). }\end{array}$ & Pages 37-43 \\
\hline \hline Summary of evidence & 25 & $\begin{array}{l}\text { Discuss limitations at study and outcome level (e.g., risk of } \\
\text { bias), and at review-level (e.g., incomplete retrieval of } \\
\text { identified research, reporting bias). }\end{array}$ & Pages 37-43 \\
\hline \hline Limitations & 26 & $\begin{array}{l}\text { Provide a general interpretation of the results in the context of } \\
\text { other evidence, and implications for future research. }\end{array}$ & Pages 37-43 \\
\hline \hline Conclusions & \multicolumn{2}{|l||l||}{} \\
\hline \hline FUNDING & 27 & $\begin{array}{l}\text { Describe sources of funding for the systematic review and } \\
\text { other support (e.g., supply of data); role of funders for the } \\
\text { systematic review. }\end{array}$ & Page 43 \\
\hline \hline
\end{tabular}


2. PRISMA 2009 Checklist for the Insulin Degrading Enzyme meta-analysis.

\begin{tabular}{|c|c|c|c|}
\hline Section/topic & $\#$ & Checklist item & Reported on page \# \\
\hline \multicolumn{4}{|l|}{ TITLE } \\
\hline Title & 1 & $\begin{array}{l}\text { Identify the report as a systematic review, meta-analysis, or } \\
\text { both. }\end{array}$ & $\begin{array}{l}\text { Not applicable (NA) since meta-analyses } \\
\text { is one of the methods used to address the } \\
\text { question and not the only method. }\end{array}$ \\
\hline \multicolumn{4}{|l|}{ ABSTRACT } \\
\hline Structured summary & 2 & $\begin{array}{l}\text { Provide a structured summary including, as applicable: } \\
\text { background; objectives; data sources; study eligibility } \\
\text { criteria, participants, and interventions; study appraisal and } \\
\text { synthesis methods; results; limitations; conclusions and } \\
\text { implications of key findings; systematic review registration } \\
\text { number. }\end{array}$ & 2 \\
\hline \multicolumn{4}{|l|}{ INTRODUCTION } \\
\hline Rationale & 3 & $\begin{array}{l}\text { Describe the rationale for the review in the context of what is } \\
\text { already known. }\end{array}$ & 5 , Line 50 \\
\hline Objectives & 4 & $\begin{array}{l}\text { Provide an explicit statement of questions being addressed } \\
\text { with reference to participants, interventions, comparisons, } \\
\text { outcomes, and study design (PICOS). }\end{array}$ & Pages 16-17 \\
\hline \multicolumn{4}{|l|}{$\begin{array}{l}\text { METHODS } \\
\end{array}$} \\
\hline Protocol and registration & 5 & $\begin{array}{l}\text { Indicate if a review protocol exists, if and where it can be } \\
\text { accessed (e.g., Web address), and, if available, provide } \\
\text { registration information including registration number. }\end{array}$ & NA \\
\hline Eligibility criteria & 6 & $\begin{array}{l}\text { Specify study characteristics (e.g., PICOS, length of follow- } \\
\text { up) and report characteristics (e.g., years considered, }\end{array}$ & NA \\
\hline
\end{tabular}




\begin{tabular}{|c|c|c|c|}
\hline & & $\begin{array}{l}\text { language, publication status) used as criteria for eligibility, } \\
\text { giving rationale. }\end{array}$ & \\
\hline Information sources & 7 & $\begin{array}{l}\text { Describe all information sources (e.g., databases with dates of } \\
\text { coverage, contact with study authors to identify additional } \\
\text { studies) in the search and date last searched. }\end{array}$ & $\begin{array}{l}\text { Pages 16-18: Table } 3, \\
\text { Page 50,53: Supplementary information } 1\end{array}$ \\
\hline Search & 8 & $\begin{array}{l}\text { Present full electronic search strategy for at least one } \\
\text { database, including any limits used, such that it could be } \\
\text { repeated. }\end{array}$ & $\begin{array}{l}\text { Pages 16-17: Table 3, } \\
\text { Page 50,53: Supplementary information } 1\end{array}$ \\
\hline Study selection & 9 & $\begin{array}{l}\text { State the process for selecting studies (i.e., screening, } \\
\text { eligibility, included in systematic review, and, if applicable, } \\
\text { included in the meta-analysis). }\end{array}$ & $\begin{array}{l}\text { Pages 16-17: Table 3, } \\
\text { Page 50,53: Supplementary information } 1\end{array}$ \\
\hline Data collection process & 10 & $\begin{array}{l}\text { Describe method of data extraction from reports (e.g., piloted } \\
\text { forms, independently, in duplicate) and any processes for } \\
\text { obtaining and confirming data from investigators. }\end{array}$ & $\begin{array}{l}\text { Data extraction: Page 50: Supplementary } \\
\text { information } 1 \\
\text { No process for obtaining and confirming } \\
\text { data from investigators, only published } \\
\text { data used. }\end{array}$ \\
\hline Data items & 11 & $\begin{array}{l}\text { List and define all variables for which data were sought (e.g., } \\
\text { PICOS, funding sources) and any assumptions and } \\
\text { simplifications made. }\end{array}$ & Page 50: Supplementary information 1 \\
\hline $\begin{array}{l}\text { Risk of bias in } \\
\text { individual studies }\end{array}$ & 12 & $\begin{array}{l}\text { Describe methods used for assessing risk of bias of individual } \\
\text { studies (including specification of whether this was done at } \\
\text { the study or outcome level), and how this information is to be } \\
\text { used in any data synthesis. }\end{array}$ & NA \\
\hline Summary measures & 13 & $\begin{array}{l}\text { State the principal summary measures (e.g., risk ratio, } \\
\text { difference in means). }\end{array}$ & $\begin{array}{l}\text { Difference in means with the 95\% } \\
\text { Confidence Intervals of the means. (Page } \\
\text { 50: Supplementary information 1) }\end{array}$ \\
\hline Synthesis of results & 14 & $\begin{array}{l}\text { Describe the methods of handling data and combining results } \\
\text { of studies, if done, including measures of consistency (e.g., }\end{array}$ & NA \\
\hline
\end{tabular}




\begin{tabular}{|c|c|c|c|}
\hline & & $\mathrm{I}^{2}$ ) for each meta-analysis. & \\
\hline $\begin{array}{l}\text { Risk of bias across } \\
\text { studies }\end{array}$ & 15 & $\begin{array}{l}\text { Specify any assessment of risk of bias that may affect the } \\
\text { cumulative evidence (e.g., publication bias, selective } \\
\text { reporting within studies). }\end{array}$ & NA \\
\hline Additional analyses & 16 & $\begin{array}{l}\text { Describe methods of additional analyses (e.g., sensitivity or } \\
\text { subgroup analyses, meta-regression), if done, indicating } \\
\text { which were pre-specified. }\end{array}$ & NA \\
\hline \multicolumn{4}{|l|}{ RESULTS } \\
\hline Study selection & 17 & $\begin{array}{l}\text { Give numbers of studies screened, assessed for eligibility, and } \\
\text { included in the review, with reasons for exclusions at each } \\
\text { stage, ideally with a flow diagram. }\end{array}$ & Pages 16-17: Table 3, \\
\hline Study characteristics & 18 & $\begin{array}{l}\text { For each study, present characteristics for which data were } \\
\text { extracted (e.g., study size, PICOS, follow-up period) and } \\
\text { provide the citations. }\end{array}$ & $\begin{array}{l}\text { Page 53: Supplementary information } 1 \text {, } \\
\text { Table } 2\end{array}$ \\
\hline $\begin{array}{l}\text { Risk of bias within } \\
\text { studies }\end{array}$ & 19 & $\begin{array}{l}\text { Present data on risk of bias of each study and, if available, } \\
\text { any outcome level assessment (see item 12). }\end{array}$ & NA \\
\hline $\begin{array}{l}\text { Results of individual } \\
\text { studies }\end{array}$ & 20 & $\begin{array}{l}\text { For all outcomes considered (benefits or harms), present, for } \\
\text { each study: (a) simple summary data for each intervention } \\
\text { group (b) effect estimates and confidence intervals, ideally } \\
\text { with a forest plot. }\end{array}$ & $\begin{array}{l}\text { (a) Pages 53: Supplementary } \\
\text { information } 1 \\
\text { (b) Figure } 5 \text { in the paper } \\
\text { (c) Table } 4 \text { in the paper }\end{array}$ \\
\hline Synthesis of results & 21 & $\begin{array}{l}\text { Present results of each meta-analysis done, including } \\
\text { confidence intervals and measures of consistency. }\end{array}$ & $\begin{array}{l}\text { Pages } 18-20 \text { in the paper } \\
\text { Figure } 5 \text { in the paper } \\
\text { Table } 4 \text { in the paper }\end{array}$ \\
\hline $\begin{array}{l}\text { Risk of bias across } \\
\text { studies }\end{array}$ & 22 & $\begin{array}{l}\text { Present results of any assessment of risk of bias across studies } \\
\text { (see Item 15). }\end{array}$ & NA \\
\hline
\end{tabular}




\begin{tabular}{||l||l||l||l||}
\hline Additional analysis & 23 & $\begin{array}{l}\text { Give results of additional analyses, if done (e.g., sensitivity or } \\
\text { subgroup analyses, meta-regression [see Item 16]). }\end{array}$ & NA \\
\hline DISCUSSION & 24 & $\begin{array}{l}\text { Summarize the main findings including the strength of } \\
\text { evidence for each main outcome; consider their relevance to } \\
\text { key groups (e.g., healthcare providers, users, and policy } \\
\text { makers). }\end{array}$ & Pages 37-43 \\
\hline \hline Summary of evidence & 25 & $\begin{array}{l}\text { Discuss limitations at study and outcome level (e.g., risk of } \\
\text { bias), and at review-level (e.g., incomplete retrieval of } \\
\text { identified research, reporting bias). }\end{array}$ & Pages 37-43 \\
\hline \hline Limitations & 26 & $\begin{array}{l}\text { Pages 37-43 } \\
\text { Conclusions }\end{array}$ & \multicolumn{2}{|l||l||}{} \\
\hline \hline FUNDING & 27 & $\begin{array}{l}\text { Describe sources of funding for the systematic review and } \\
\text { other support (e.g., supply of data); role of funders for the } \\
\text { systematic review. }\end{array}$ & Page 43 \\
\hline \hline Funding &
\end{tabular}


3. PRISMA 2009 Checklist for the Insulin Suppression by Diazoxide meta-analysis.

\begin{tabular}{|c|c|c|c|}
\hline Section/topic & $\#$ & Checklist item & Reported on page \# \\
\hline \multicolumn{4}{|l|}{ TITLE } \\
\hline Title & 1 & $\begin{array}{l}\text { Identify the report as a systematic review, meta-analysis, or } \\
\text { both. }\end{array}$ & $\begin{array}{l}\text { Not applicable (NA) since meta-analyses } \\
\text { is one of the methods used to address the } \\
\text { question and not the only method. }\end{array}$ \\
\hline \multicolumn{4}{|l|}{ ABSTRACT } \\
\hline Structured summary & 2 & $\begin{array}{l}\text { Provide a structured summary including, as applicable: } \\
\text { background; objectives; data sources; study eligibility } \\
\text { criteria, participants, and interventions; study appraisal and } \\
\text { synthesis methods; results; limitations; conclusions and } \\
\text { implications of key findings; systematic review registration } \\
\text { number. }\end{array}$ & 2 \\
\hline \multicolumn{4}{|l|}{ INTRODUCTION } \\
\hline Rationale & 3 & $\begin{array}{l}\text { Describe the rationale for the review in the context of what is } \\
\text { already known. }\end{array}$ & 5 , Line 50 \\
\hline Objectives & 4 & $\begin{array}{l}\text { Provide an explicit statement of questions being addressed } \\
\text { with reference to participants, interventions, comparisons, } \\
\text { outcomes, and study design (PICOS). }\end{array}$ & Pages 15-17 \\
\hline \multicolumn{4}{|l|}{$\begin{array}{l}\text { METHODS } \\
\end{array}$} \\
\hline Protocol and registration & 5 & $\begin{array}{l}\text { Indicate if a review protocol exists, if and where it can be } \\
\text { accessed (e.g., Web address), and, if available, provide } \\
\text { registration information including registration number. }\end{array}$ & NA \\
\hline Eligibility criteria & 6 & $\begin{array}{l}\text { Specify study characteristics (e.g., PICOS, length of follow- } \\
\text { up) and report characteristics (e.g., years considered, }\end{array}$ & NA \\
\hline
\end{tabular}




\begin{tabular}{|c|c|c|c|}
\hline & & $\begin{array}{l}\text { language, publication status) used as criteria for eligibility, } \\
\text { giving rationale. }\end{array}$ & \\
\hline Information sources & 7 & $\begin{array}{l}\text { Describe all information sources (e.g., databases with dates of } \\
\text { coverage, contact with study authors to identify additional } \\
\text { studies) in the search and date last searched. }\end{array}$ & $\begin{array}{l}\text { Page 50,53,54: Supplementary } \\
\text { information } 1, \text { Table } 3\end{array}$ \\
\hline Search & 8 & $\begin{array}{l}\text { Present full electronic search strategy for at least one } \\
\text { database, including any limits used, such that it could be } \\
\text { repeated. }\end{array}$ & $\begin{array}{l}\text { Pages } 20-21 \text {, Table } 5 \text { in the paper } \\
\text { Pages } 50,53 \text { and } 54 \text { in the Supplementary } \\
\text { information } 1 \text {, Table } 3\end{array}$ \\
\hline Study selection & 9 & $\begin{array}{l}\text { State the process for selecting studies (i.e., screening, } \\
\text { eligibility, included in systematic review, and, if applicable, } \\
\text { included in the meta-analysis). }\end{array}$ & $\begin{array}{l}\text { Pages } 20-21 \text {, Table } 5 \text { in the paper } \\
\text { Pages } 50,53 \text { and } 54 \text { in the Supplementary } \\
\text { information } 1 \text {, Table } 3\end{array}$ \\
\hline Data collection process & 10 & $\begin{array}{l}\text { Describe method of data extraction from reports (e.g., piloted } \\
\text { forms, independently, in duplicate) and any processes for } \\
\text { obtaining and confirming data from investigators. }\end{array}$ & $\begin{array}{l}\text { Data extraction: Page 50: Supplementary } \\
\text { information } 1 \\
\text { No process for obtaining and confirming } \\
\text { data from investigators, only published } \\
\text { data used. }\end{array}$ \\
\hline Data items & 11 & $\begin{array}{l}\text { List and define all variables for which data were sought (e.g., } \\
\text { PICOS, funding sources) and any assumptions and } \\
\text { simplifications made. }\end{array}$ & Page 50: Supplementary information 1 \\
\hline $\begin{array}{l}\text { Risk of bias in } \\
\text { individual studies }\end{array}$ & 12 & $\begin{array}{l}\text { Describe methods used for assessing risk of bias of individual } \\
\text { studies (including specification of whether this was done at } \\
\text { the study or outcome level), and how this information is to be } \\
\text { used in any data synthesis. }\end{array}$ & NA \\
\hline Summary measures & 13 & $\begin{array}{l}\text { State the principal summary measures (e.g., risk ratio, } \\
\text { difference in means). }\end{array}$ & $\begin{array}{l}\text { Difference in means with the } 95 \% \\
\text { Confidence Intervals of the means. (Page } \\
\text { 50: Supplementary information 1) }\end{array}$ \\
\hline Synthesis of results & 14 & $\begin{array}{l}\text { Describe the methods of handling data and combining results } \\
\text { of studies, if done, including measures of consistency (e.g., }\end{array}$ & NA \\
\hline
\end{tabular}




\begin{tabular}{|c|c|c|c|}
\hline & & $\mathrm{I}^{2}$ ) for each meta-analysis. & \\
\hline $\begin{array}{l}\text { Risk of bias across } \\
\text { studies }\end{array}$ & 15 & $\begin{array}{l}\text { Specify any assessment of risk of bias that may affect the } \\
\text { cumulative evidence (e.g., publication bias, selective } \\
\text { reporting within studies). }\end{array}$ & NA \\
\hline Additional analyses & 16 & $\begin{array}{l}\text { Describe methods of additional analyses (e.g., sensitivity or } \\
\text { subgroup analyses, meta-regression), if done, indicating } \\
\text { which were pre-specified. }\end{array}$ & NA \\
\hline \multicolumn{4}{|l|}{ RESULTS } \\
\hline Study selection & 17 & $\begin{array}{l}\text { Give numbers of studies screened, assessed for eligibility, and } \\
\text { included in the review, with reasons for exclusions at each } \\
\text { stage, ideally with a flow diagram. }\end{array}$ & $\begin{array}{l}\text { Pages } 20-21 \text {, Table } 5 \text { in the paper } \\
\text { Pages } 50,53 \text { and } 54 \text { in the Supplementary } \\
\text { information } 1 \text {, Table } 3\end{array}$ \\
\hline Study characteristics & 18 & $\begin{array}{l}\text { For each study, present characteristics for which data were } \\
\text { extracted (e.g., study size, PICOS, follow-up period) and } \\
\text { provide the citations. }\end{array}$ & Page 50: Supplementary information 1 \\
\hline $\begin{array}{l}\text { Risk of bias within } \\
\text { studies }\end{array}$ & 19 & $\begin{array}{l}\text { Present data on risk of bias of each study and, if available, } \\
\text { any outcome level assessment (see item 12). }\end{array}$ & NA \\
\hline $\begin{array}{l}\text { Results of individual } \\
\text { studies }\end{array}$ & 20 & $\begin{array}{l}\text { For all outcomes considered (benefits or harms), present, for } \\
\text { each study: (a) simple summary data for each intervention } \\
\text { group (b) effect estimates and confidence intervals, ideally } \\
\text { with a forest plot. }\end{array}$ & $\begin{array}{l}\text { (a) Pages } 53 \text { to 54: Supplementary } \\
\text { information 1, Table } 3 \\
\text { (b) Page 22, Table } 6 \text { in the paper } \\
\text { (c) Page 23, Figure } 6 \text { in the paper }\end{array}$ \\
\hline Synthesis of results & 21 & $\begin{array}{l}\text { Present results of each meta-analysis done, including } \\
\text { confidence intervals and measures of consistency. }\end{array}$ & Pages 22,23 \\
\hline $\begin{array}{l}\text { Risk of bias across } \\
\text { studies }\end{array}$ & 22 & $\begin{array}{l}\text { Present results of any assessment of risk of bias across studies } \\
\text { (see Item 15). }\end{array}$ & NA \\
\hline Additional analysis & 23 & $\begin{array}{l}\text { Give results of additional analyses, if done (e.g., sensitivity or } \\
\text { subgroup analyses, meta-regression [see Item 16]). }\end{array}$ & NA \\
\hline
\end{tabular}




\begin{tabular}{|c|c|c|c|}
\hline \multicolumn{4}{|l|}{ DISCUSSION } \\
\hline Summary of evidence & 24 & $\begin{array}{l}\text { Summarize the main findings including the strength of } \\
\text { evidence for each main outcome; consider their relevance to } \\
\text { key groups (e.g., healthcare providers, users, and policy } \\
\text { makers). }\end{array}$ & Pages 37-43 \\
\hline Limitations & 25 & $\begin{array}{l}\text { Discuss limitations at study and outcome level (e.g., risk of } \\
\text { bias), and at review-level (e.g., incomplete retrieval of } \\
\text { identified research, reporting bias). }\end{array}$ & Pages 37-43 \\
\hline Conclusions & 26 & $\begin{array}{l}\text { Provide a general interpretation of the results in the context of } \\
\text { other evidence, and implications for future research. }\end{array}$ & Page 37-43 \\
\hline \multicolumn{4}{|l|}{ FUNDING } \\
\hline Funding & 27 & $\begin{array}{l}\text { Describe sources of funding for the systematic review and } \\
\text { other support (e.g., supply of data); role of funders for the } \\
\text { systematic review. }\end{array}$ & Page 43 \\
\hline
\end{tabular}

4. PRISMA 2009 Checklist for the Insulin Suppression by Octreotide meta-analysis.

\begin{tabular}{|l||l|l|l||l||}
\hline Section/topic & $\#$ & Checklist item & Reported on page \# \\
\hline \hline TITLE & 1 & $\begin{array}{l}\text { Identify the report as a systematic review, meta-analysis, or } \\
\text { both. }\end{array}$ & $\begin{array}{l}\text { Not applicable (NA) since meta-analyses } \\
\text { is one of the methods used to address the } \\
\text { question and not the only method. }\end{array}$ \\
\hline \hline Title & \\
\hline \hline ABSTRACT
\end{tabular}




\begin{tabular}{|c|c|c|c|}
\hline Structured summary & 2 & $\begin{array}{l}\text { Provide a structured summary including, as applicable: } \\
\text { background; objectives; data sources; study eligibility } \\
\text { criteria, participants, and interventions; study appraisal and } \\
\text { synthesis methods; results; limitations; conclusions and } \\
\text { implications of key findings; systematic review registration } \\
\text { number. }\end{array}$ & 2 \\
\hline \multicolumn{3}{|l|}{ INTRODUCTION } & \\
\hline Rationale & 3 & $\begin{array}{l}\text { Describe the rationale for the review in the context of what is } \\
\text { already known. }\end{array}$ & 5 , Line 50 \\
\hline Objectives & 4 & $\begin{array}{l}\text { Provide an explicit statement of questions being addressed } \\
\text { with reference to participants, interventions, comparisons, } \\
\text { outcomes, and study design (PICOS). }\end{array}$ & Pages 15-17 \\
\hline \multicolumn{3}{|l|}{ METHODS } & \\
\hline Protocol and registration & 5 & $\begin{array}{l}\text { Indicate if a review protocol exists, if and where it can be } \\
\text { accessed (e.g., Web address), and, if available, provide } \\
\text { registration information including registration number. }\end{array}$ & NA \\
\hline Eligibility criteria & 6 & $\begin{array}{l}\text { Specify study characteristics (e.g., PICOS, length of follow- } \\
\text { up) and report characteristics (e.g., years considered, } \\
\text { language, publication status) used as criteria for eligibility, } \\
\text { giving rationale. }\end{array}$ & NA \\
\hline Information sources & 7 & $\begin{array}{l}\text { Describe all information sources (e.g., databases with dates of } \\
\text { coverage, contact with study authors to identify additional } \\
\text { studies) in the search and date last searched. }\end{array}$ & $\begin{array}{l}\text { Page } 50,55,56: \text { Supplementary } \\
\text { information } 1, \text { Table } 4\end{array}$ \\
\hline Search & 8 & $\begin{array}{l}\text { Present full electronic search strategy for at least one } \\
\text { database, including any limits used, such that it could be } \\
\text { repeated. }\end{array}$ & $\begin{array}{l}\text { Pages } 20-21 \text { in the paper, Table } 5 \\
\text { Page 50,55,56: Supplementary } \\
\text { information } 1 \text {, Table } 4\end{array}$ \\
\hline Study selection & 9 & $\begin{array}{l}\text { State the process for selecting studies (i.e., screening, } \\
\text { eligibility, included in systematic review, and, if applicable, }\end{array}$ & $\begin{array}{l}\text { Pages } 20-21 \text { in the paper, Table } 5 \\
\text { Page 50,55,56: Supplementary }\end{array}$ \\
\hline
\end{tabular}




\begin{tabular}{|c|c|c|c|}
\hline & & included in the meta-analysis). & information 1 , Table 4 \\
\hline Data collection process & 10 & $\begin{array}{l}\text { Describe method of data extraction from reports (e.g., piloted } \\
\text { forms, independently, in duplicate) and any processes for } \\
\text { obtaining and confirming data from investigators. }\end{array}$ & $\begin{array}{l}\text { Data extraction: Page 50: Supplementary } \\
\text { information } 1 \\
\text { No process for obtaining and confirming } \\
\text { data from investigators, only published } \\
\text { data used. }\end{array}$ \\
\hline Data items & 11 & $\begin{array}{l}\text { List and define all variables for which data were sought (e.g., } \\
\text { PICOS, funding sources) and any assumptions and } \\
\text { simplifications made. }\end{array}$ & Page 50: Supplementary information 1 \\
\hline $\begin{array}{l}\text { Risk of bias in } \\
\text { individual studies }\end{array}$ & 12 & $\begin{array}{l}\text { Describe methods used for assessing risk of bias of individual } \\
\text { studies (including specification of whether this was done at } \\
\text { the study or outcome level), and how this information is to be } \\
\text { used in any data synthesis. }\end{array}$ & NA \\
\hline Summary measures & 13 & $\begin{array}{l}\text { State the principal summary measures (e.g., risk ratio, } \\
\text { difference in means). }\end{array}$ & $\begin{array}{l}\text { Difference in means with the 95\% } \\
\text { Confidence Intervals of the means. (Page } \\
\text { 50: Supplementary information 1) }\end{array}$ \\
\hline Synthesis of results & 14 & $\begin{array}{l}\text { Describe the methods of handling data and combining results } \\
\text { of studies, if done, including measures of consistency (e.g., } \\
\mathrm{I}^{2} \text { ) for each meta-analysis. }\end{array}$ & NA \\
\hline $\begin{array}{l}\text { Risk of bias across } \\
\text { studies }\end{array}$ & 15 & $\begin{array}{l}\text { Specify any assessment of risk of bias that may affect the } \\
\text { cumulative evidence (e.g., publication bias, selective } \\
\text { reporting within studies). }\end{array}$ & NA \\
\hline Additional analyses & 16 & $\begin{array}{l}\text { Describe methods of additional analyses (e.g., sensitivity or } \\
\text { subgroup analyses, meta-regression), if done, indicating } \\
\text { which were pre-specified. }\end{array}$ & NA \\
\hline LS & & & \\
\hline
\end{tabular}




\begin{tabular}{|c|c|c|c|}
\hline Study selection & 17 & $\begin{array}{l}\text { Give numbers of studies screened, assessed for eligibility, and } \\
\text { included in the review, with reasons for exclusions at each } \\
\text { stage, ideally with a flow diagram. }\end{array}$ & $\begin{array}{l}\text { Pages } 20-21 \text {, Table } 5 \text { in the paper } \\
\text { Pages } 50,55 \text { and } 56 \text { in the Supplementary } \\
\text { information } 1 \text {, Table } 4\end{array}$ \\
\hline Study characteristics & 18 & $\begin{array}{l}\text { For each study, present characteristics for which data were } \\
\text { extracted (e.g., study size, PICOS, follow-up period) and } \\
\text { provide the citations. }\end{array}$ & Page 52: Supplementary information 1 \\
\hline $\begin{array}{l}\text { Risk of bias within } \\
\text { studies }\end{array}$ & 19 & $\begin{array}{l}\text { Present data on risk of bias of each study and, if available, } \\
\text { any outcome level assessment (see item 12). }\end{array}$ & NA \\
\hline $\begin{array}{l}\text { Results of individual } \\
\text { studies }\end{array}$ & 20 & $\begin{array}{l}\text { For all outcomes considered (benefits or harms), present, for } \\
\text { each study: (a) simple summary data for each intervention } \\
\text { group (b) effect estimates and confidence intervals, ideally } \\
\text { with a forest plot. }\end{array}$ & $\begin{array}{l}\text { (a) Pages } 55 \text { to } 56 \text { : Supplementary } \\
\text { information } 1 \text {, Table } 4 \\
\text { (b) Page 22, Table } 6 \text { in the paper } \\
\text { (c) Page 23, Figure } 6 \text { in the paper }\end{array}$ \\
\hline Synthesis of results & 21 & $\begin{array}{l}\text { Present results of each meta-analysis done, including } \\
\text { confidence intervals and measures of consistency. }\end{array}$ & Pages 22,23 in the paper \\
\hline $\begin{array}{l}\text { Risk of bias across } \\
\text { studies }\end{array}$ & 22 & $\begin{array}{l}\begin{array}{l}\text { Present results of any assessment of risk of bias across studies } \\
\text { (see Item 15). }\end{array} \\
\end{array}$ & NA \\
\hline Additional analysis & 23 & $\begin{array}{l}\text { Give results of additional analyses, if done (e.g., sensitivity or } \\
\text { subgroup analyses, meta-regression [see Item 16]). }\end{array}$ & NA \\
\hline \multicolumn{4}{|l|}{ DISCUSSION } \\
\hline Summary of evidence & 24 & $\begin{array}{l}\text { Summarize the main findings including the strength of } \\
\text { evidence for each main outcome; consider their relevance to } \\
\text { key groups (e.g., healthcare providers, users, and policy } \\
\text { makers). }\end{array}$ & Pages 37-43 \\
\hline Limitations & 25 & $\begin{array}{l}\text { Discuss limitations at study and outcome level (e.g., risk of } \\
\text { bias), and at review-level (e.g., incomplete retrieval of } \\
\text { identified research, reporting bias). }\end{array}$ & Pages 37-43 \\
\hline
\end{tabular}




\begin{tabular}{||l||l|l||l||}
\hline \hline Conclusions & 26 & $\begin{array}{l}\text { Provide a general interpretation of the results in the context of } \\
\text { other evidence, and implications for future research. }\end{array}$ & Page 37-43 \\
\hline \hline FUNDING & 27 & $\begin{array}{l}\text { Describe sources of funding for the systematic review and } \\
\text { other support (e.g., supply of data); role of funders for the } \\
\text { systematic review. }\end{array}$ & Page 43 \\
\hline \hline Funding &
\end{tabular}

From: Moher D, Liberati A, Tetzlaff J, Altman DG, The PRISMA Group (2009). Preferred Reporting Items for Systematic Reviews and Meta-Analyses: The PRISMA Statement. PLoS Med 6(7): 